\title{
EDUARDO LISTIK
}

Otimização da síntese e desenvolvimento de sistemas nanoparticulados poliméricos e lipossomais para aplicações em células derivadas do sistema nervoso central

\begin{abstract}
Dissertação apresentada ao Progama de Pós-Graduação em Farmacologia do Instituto de Ciências Biomédicas da Universidade de São Paulo, para obtenção do Título de Mestre em Ciências.
\end{abstract}

São Paulo 


\section{EDUARDO LISTIK}

Otimização da síntese e desenvolvimento de sistemas nanoparticulados poliméricos e lipossomais para aplicações em células derivadas do sistema nervoso central

Dissertação apresentada ao Progama de Pós-Graduação em Farmacologia do Instituto de Ciências Biomédicas da Universidade de São Paulo, para obtenção do Título de Mestre em Ciências.

Área de concentração:

Farmacologia

Orientadora: Profa. Dra. Rosana Camarini

Versão Original

São Paulo 
CATALOGAÇÃO NA PUBLICAÇÃO (CIP)

Serviço de Biblioteca e informação Biomédica

do Instituto de Ciências Biomédicas da Universidade de São Paulo

Ficha Catalográfica elaborada pelo(a) autor(a)

Listik, Eduardo

otimização da sintese e desenvolvimento de sistemas nanoparticulados poliméricos e lipossomais para aplicações em células derivadas do sistema

nervoso central / Eduardo Listik; orientadora Rosana Camarini. -- São Paulo, 2017.

$$
90 \mathrm{p} \text {. }
$$

Dissertação (Mestrado) ) -- Universidade de são Paulo, Instituto de Ciências Biomédicas.

1. Nanopartículas poliméricas. 2 .

Imunolipossomos. 3. Sistema nervoso central. 4. Citotoxicidade. I. Camarini, Rosana, orientador. II. Título. 
Candidato(a): Eduardo Listik

Titulo da Dissertação/Tese: Otimização da síntese e desenvolvimento de sistemas nanoparticulados poliméricos e lipossomais para aplicações em células derivadas do sistema nervoso central.

Orientadora: Profa. Dra. Rosana Camarini

A Comissão Julgadora dos trabalhos de Defesa da Dissertação de Mestrado/Tese de Doutorado, em sessão publica realizada a ............................., considerou o candidato: Eduardo Listik

\section{( ) Aprovado(a) ( ) Reprovado(a)}

Examinador(a):

Assinatura:

Nome:

Instituição:

Examinador(a):

Assinatura:

Nome:

Instituição:

Examinador(a):

Assinatura:

Nome:

Instituição:

Presidente:

Assinatura:

Nome:

Instituição: 


\section{CERTIFICADO DE ISENÇÃO}

Certificamos que o Protocolo CEP-ICB N ${ }^{0}$ 754/15 referente ao projeto intitulado: "Confecção de sistemas nanoparticulado e lipossomal contendo 17Beta-estradiol e a comparação de sua eficácia neuroprotetora sítio-dirigida" sob a responsabilidade de Eduardo Listik, e orientação da Profa. Dra. Carolina Demarchi Munhoz, do Departamento de Farmacologia, foi analisado na presente data pela CEUA - COMISSÃO DE ÉTICA NO USO DE ANIMAIS e pela CEPSH- Comissão de Ética em Pesquisa com Seres Humanos, tendo sido deliberado que o referido projeto não utilizará animais que estejam sob a égide da Lei $\mathrm{n}^{\circ}$ 11.794, de 8 de outubro de 2008, nem envolverá procedimentos regulados pela Resolução CONEP no 466 de 2012.

São Paulo, 31 de agosto de 2015.

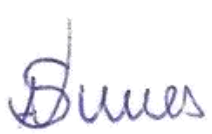

PROF. DR. ANDERSON DE SÁ NUNES Coordenador da CEUA - ICB/USP

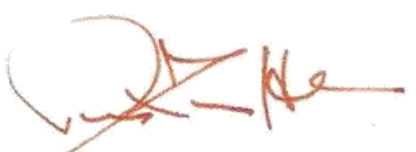

PROF. DR. PAOLO M. A ZANOTTO

Coordenador da CEPSH - ICB/USP 
Dedicatória

Os bons frutos advindos desta fase estão dedicados a Ruth

Franscisconi (in memoriam). 


\section{AGRADECIMENTOS}

Agradecimento que devo à minha família: meu pai Dr. Sergio Listik, minha mãe Dra. Marcia Listik e minha irmã Dra. Clarice Listik; os quais sempre me apoiaram, me instruíram, me fortaleceram e me aconselharam nesta, e em todas as outras, fases da minha vida. Foram eles que notaram, se preocuparam e mais valorizaram as inúmeras noites varadas nos laboratórios e me patrocinaram para as atividades em instituições no exterior, de forma a aprimorar minha formação científica. Lembro também meu tio, Roberto Listik, sempre interessado em minhas atividades e delas participativo delas, torcendo pelo meu sucesso; e minha tia, Dra. Myriam Sapucahy Lins, que esteve presente nos momentos mais difíceis, auxiliando-me com o seu máximo.

Agradeço também o acolhimento, a amizade e o prazer de ter dividido inúmeras horas dos dias, quer entre experimentos ou no lazer, aos colegas, citando com o mais profundo carinho, a amiga Ms. Flávia Neto de Jesus.

Não posso, tampouco devo esquecer da maior colega e amiga Mariana Guedes da Silva Franchi, que me aturou nos longos anos da Graduação e até hoje me presenteia com o seu carinho, bem com o de sua família.

Devo especial agradecimento à Dra. Sonja Ellen Lobo e à Ms. Flávia Neto de Jesus, que me auxiliaram quer na revisão conceitual deste documento, quer na elaboração de uma dissertação mais íntegra e bem elaborada, qualidades essenciais para um documento deste tipo.

Agradeço, por fim, à Comissão de Aperfeiçoamento de Pessoal de Nível Superior (CAPES), a qual garantiu meu subsídio durante esta fase; à Fundação de Amparo à Pesquisa do Estado de São Paulo (FAPESP), e ao Conselho Nacional de Desenvolvimento Científico e Tecnológico (CNPq) que possibilitaram o desenvolver desta pesquisa.

A todos estes agradeço. 
"É melhor que fale por nós a nossa vida, que as nossas palavras".

Mohandas Karamchand Ghandi 


\section{RESUMO}

Listik, E. Otimização da síntese e desenvolvimento de sistemas nanoparticulados poliméricos e lipossomais para aplicações em células derivadas do sistema nervoso central. Dissertação (Mestrado em Farmacologia) Instituto de Ciências Biomédicas, Universidade de São Paulo, São Paulo, 2017.

Dentre as diversas aplicações nanotecnológicas, a terapêutica atrelada aos nanocarreadores é destaque indubitável. O presente trabalho tem como intuito avaliar e otimizar o processo de confecção e as propriedades de nanopartículas poliméricas (NPs) e de lipossomos (LPs) com capacidade de acessar células do sistema nervoso central, para o transporte de substâncias de interesse visando o tratamento e prevenção de doenças. Desta forma, foi proposta a otimização da obtenção de nanopartículas poliméricas com polissorbato-80 (T-80) adsorvido e os imunolipossomos funcionalizados com anticorpo anti-transferrina. As NPs foram confeccionadas pelo método de emulsificação em óleo-água seguido de sonicação utilizando poli(D, L-lactato-co-glicolato) (PLGA) como polímero estrutural. A influência de diversos parâmetros, tais como 0 tipo de tensoativo (brometo de didodecildimetilamônio - DMAB, ou brometo de didecildimetilamônio - DDAB), regime de sonicação, volume de solução de T-80 e tipo de agitador sobre o tamanho, polidispersão e potencial zeta das NPs foi avaliada a fim de otimizar o processo de produção. LPs foram obtidos pelo método de hidratação de filme lipídico seguido de sonicação utilizando mistura de fosfolipídeos contendo DPPC:CH:DSPE-PEG ${ }^{2000}$ ou DOPC:CH:DSPE-PEG ${ }^{2000}$ nas proporções molares de 4:1:0,2 e DSPE-PEG ${ }^{2000}-M A L$ + (Transf-Abm). O emprego de DMAB na confecção de NPs revelou uma tendência em se obter partículas menos polidispersas e com melhor estabilidade. Ademais LPs sintetizados com dioleilfosfatidilcolina (DOPC) possuíram vesículas de tamanho consideravelmente menor que quando constituídos com dipalpitoilfosfatidilcolina (DPPC). Tanto o perfil citotóxico como a internalização dos carreadores foram testadas em células $\mathrm{N} 2 a$ e/ou SH-SY5Y por até $24 \mathrm{~h}$. Os resultados obtidos mostraram que NPs recobertas com T-80 apresentavam um perfil citotóxico e requeriam no mínimo $12 \mathrm{~h}$ para serem internalizadas, ao passo que LPs não apresentaram citotoxidade e foram captados pelas células neuronais em até $30 \mathrm{~min}$. Com as conclusões alcançadas neste trabalho, deseja-se evidenciar que a confecção de nanocarreadores, ainda mais aqueles com o complexo objetivo de transpor a barreira hematoencefálica, é um processo delicado e que deve usufruir de investigação pormenorizada para melhores resultados na aplicação biológica e clínica.

Palavras-chave: Nanopartículas. Imunolipossomos. Sistema Nervoso Central. Citotoxicidade. 


\begin{abstract}
Listik, E. Synthesis optimization and development of polymeric nanoparticulated and liposomal systems for central nervous systems cell-derived applications. Master thesis (Pharmacology) - Instituto de Ciência Biomédicas, Universidade de São Paulo, São Paulo, 2017.
\end{abstract}

Among many nanotechnological applications, the therapeutical use of nanocarriers is of unquestionable relevance. This study aims at analyzing and optimizing the obtainment process and properties of polymeric nanoparticles (NPs) and liposomes (LPs) with the capacity of accessing central nervous system cells for the transport of substances of interest for the purpose of treatment and prevention of various diseases. In such, it was proposed to optimize the synthesis of polissorbate-80 (T-80)-coated polymeric nanoparticles and anti-transferrin antibody functionalized immunoliposomes. NPs composed of poly(lactic-co-glycolic acid) (PLGA), as the structural polymer, were obtained by the oil-in-water emulsion method followed by sonication. The influence of several paramaters, such as type of surfactant (didodecyldimethylammonium bromide - DMAB, or didecyldimethylammonium bromide - DDAB), sonication regime, T-80 solution dispersion volume and size of stirrer on the size, polidispersity and zeta potential of NPs was studied in order to optimize the process. LPs were obtained by the lipid film hydration method followed by sonication, in which a mixture of lipids containing either DPPC:CH:DSPE-PEG ${ }^{2000}$ or DOPC:CH:DSPE-PEG ${ }^{2000}$ at 4:1:0.2 molar proportions and DSPE-PEG ${ }^{2000}-M_{A L}+$ (Transf-Abm). The use of DMAB reveals a tendency of more monodisperse and stable particles. Moreover, LPs obtained with dioleylphospatidylcholine (DOPC) displayed smaller sizes than those with dipalmitoylphospatidylcholine (DPPC). Both the cytotoxic profile and the internalization of the carriers were verified on N2a and/or SH-SY5Y cells up to $24 \mathrm{~h}$. The results show that T-80-coated NPs possess a cytotoxicity profile and needed at least $12 \mathrm{~h}$ to be internalized. On the other hand, LPs did not reveal cytotoxicity and were internalized in neurons in a time frame of $30 \mathrm{~min}$. Based on these results, we conclude that the process to obtain nanocarriers, especially those aimed at central nervous system applications, is sensitive to several parameters and require detailed analysis when seeking the most favorable biological and clinical results.

Keywords: Polymeric nanoparticles. Immunoliposomes. Central Nervous System. Cytotoxicity 


\section{LISTA DE ILUSTRAÇÕES}

Figura 1 - llustração de lipossomos e nanopartículas................................... 20

Figura 2 - Fórmulas estruturais da DPPC e da DOPC.................................. 21

Figura 3 - Fórmulas estruturais do DDAB e do DMAB................................ 23

Figura 4 - Fluxograma do processo de síntese de nanopartículas

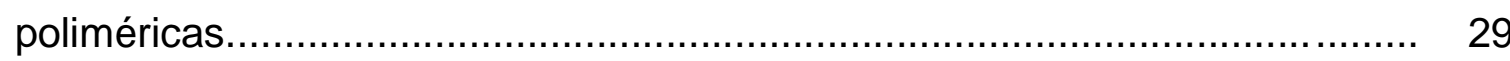

Figura 5 - Fluxograma do processo de síntese de imunolipossomos............ 32

Figura 6 - Análises em escala de probabilidade para o método fatorial $2^{2} \ldots . . \quad 40$

Figura 7 - Resultados em comparações de tratamento quanto ao regime de sonicação de nanopartículas poliméricas.

Figura 8 - Resultados em comparações de tratamento quanto ao tipo de tensoativo na síntese de nanopartículas poliméricas.

Figura 9 - Distribuições de tamanho e carga de nanopartículas poliméricas com FITC encapsulada. 47

Figura 10 - Avaliação das propriedades de FITC-NPs............................... 48

Figura 11 - Cinética de formação de lipossomos com DOPC e DPPC......... 49

Figura 12 - Averiguações no processo de síntese de imunolipossomos........ 51

Figura 13 - Avaliação da centrifugação branda em lipossomos com DPPC e DOPC.

Figura 14 - Distribuições de tamanho e carga de imunolipossomos com

FITC encapsulada.

Figura 15 - Avaliação das propriedades de FITC-LPs............................... 55

Figura 16 - Resultados da padronização do teste de viabilidade do MTT...... 56

Figura 17 - Resultados dos ensaios de citotoxicidade de nanopartículas poliméricas e lipossomos em células Neuro-2a.

Figura 18 - Resultados dos ensaios de citotoxicidade de nanopartículas poliméricas em células SHSY5Y

Figura 19 - Avaliação da internalização de FITC-NPs e FITC-LPs em Neuro-2a em 24 h - marcação com pan-caderina.

Figura 20 - Avaliação da internalização de FITC-NPs e FITC-LPs em Neuro-2a em $6 \mathrm{~h}$ - marcação com $\beta$-actina.

Figura 21 - Avaliação da internalização de FITC-NPs e FITC-LPs em SHSY5Y. 


\section{LISTA DE TABELAS}

Tabela 1 - Definição das variáveis e seus subníveis para o teste fatorial $2^{2} \ldots 38$

Tabela 2 - Exibição do planejamento experimental do teste fatorial $2^{2} \mathrm{em}$ ordem padrão.

Tabela 3 - Efeitos para cada uma das variáveis e para a interação entre elas na análise do teste fatorial $2^{2}$.

Tabela 4 - Síntese da significância dos efeitos obtidos no teste fatorial $2^{2}$ 41

Tabela 5 - Comparação das nanopartículas com ou sem a funcionalização com polissorbato-80 mediante averiguações em MEV-FEG, distribuição de tamanho e de carga

Tabela 6 - Avaliação dos parâmetros obtidos dos modelos farmacológicos nas análises de citotoxicidade. 
LISTA DE ABREVIATURAS E SIGLAS

\begin{tabular}{|c|c|}
\hline Abreviatura/Sigla & Significado \\
\hline AcEt & Acetato de etila. \\
\hline AVC & Acidente vascular cerebral. \\
\hline B16-F10 & Linhagem de melanoma murino (ATCC® CRL- $6475^{\mathrm{TM}}$ ). \\
\hline $\mathrm{BHE}$ & Barreira hematoencefálica. \\
\hline CEME & Centro de microscopia eletrônica. \\
\hline $\mathrm{CH}$ & Colesterol. \\
\hline$C_{x}$ & Cadeia carbônica com $x$ carbonos. \\
\hline DA & Doença de Alzheimer. \\
\hline DAPI & 4',6-diamino-fenilindola. \\
\hline DDAB & Brometo de didecildimetilamônio. \\
\hline $\mathrm{DH}$ & Doença de Huntington. \\
\hline DLS & $\begin{array}{l}\text { Espalhamento dinâmico de luz (do inglês Dynamic light } \\
\text { Scattering). }\end{array}$ \\
\hline DMAB & Brometo de didodecildimetilamônio. \\
\hline DMEM & Do inglês Dulbecco's Modified Eagle's Medium. \\
\hline DOPC & Dioleilfosfatidilcolina. \\
\hline DOPC-LP(s) & Lipossomos sintetizados com DOPC. \\
\hline DOTAP & Dioleitrimetilamônio propano. \\
\hline DP & Doeça de Parkinson. \\
\hline DPPC & Dipalmitoilfosfatidilcolina. \\
\hline DPPC-LP(s) & Lipossomos sintetizados com DPPC. \\
\hline DSPC & Diestearoilfosfatidilcolina. \\
\hline DSPE & Diestearoilfosfatidiletanolamina. \\
\hline FDA & Do inglês Food and Drug Administration. \\
\hline FITC & Fluorescina isotiocinato isômero I. \\
\hline FITC-BSA & Albumina sérica bovina conjugada ao fluoróforo FITC. \\
\hline FITC-LP(s) & Lipossomos com FITC encapsulada. \\
\hline FITC-NP(s) & Nanopartículas com FITC encapsulada. \\
\hline GLUT1 & Transportador de glicose 1. \\
\hline HPLC & Cromatografia líquida de alta performance. \\
\hline $\mathrm{HV}$ & Do inglês high vacuum. \\
\hline
\end{tabular}




\begin{tabular}{|c|c|}
\hline ISO & Do inglês International Organization for Standardization. \\
\hline $\mathrm{LP}(\mathrm{s})$ & Lipossomos (imunolipossomos). \\
\hline MAL & $\begin{array}{l}\text { Grupo maleimida, necessário para a conjugação do anticorpo } \\
\text { anti-transferrina. }\end{array}$ \\
\hline МС3Т3-E1 & Linhagem de osteoblastos murinos (ATCC $\AA$ CRL-2593 ${ }^{\mathrm{TM}}$ ). \\
\hline MDR1 & Gene de multirresistência a fármacos. \\
\hline MEV-FEG & $\begin{array}{l}\text { Microscopia eletrônica de varredura com emissão de campo } \\
\text { (FEG, Field emission gun). }\end{array}$ \\
\hline MTT & 3-(4-5-dimetiltiazol-2-il)-2,5-difenil-tetrazólio. \\
\hline $\mathrm{N} 2 \mathrm{a}$ & $\begin{array}{l}\text { Linhagem de neuroblastoma murino Neuro-2a (ATCC® CCL- } \\
\left.131^{\mathrm{TM}}, \mathrm{N} 2 \mathrm{a}\right) \text {. }\end{array}$ \\
\hline$N P(s)$ & $\begin{array}{l}\text { Nanopartículas poliméricas (funcionalizadas com polissorbato- } \\
80 \text { ). }\end{array}$ \\
\hline $\mathrm{NPs}(+\mathrm{T} 80)$ & Nanopartículas funcionalizadas com polissorbato- 80 . \\
\hline NPs(-T80) & $\begin{array}{l}\text { Nanopartículas que não sofreram a funcionalização com } \\
\text { polissorbato-80. }\end{array}$ \\
\hline PBCA & Polibutilcianoarilato. \\
\hline PBS & Tampão fosfato salino. \\
\hline PDI & Índice de polidispersidade. \\
\hline$P E G^{x}$ & Polietilenoglicol com cadeia de $\mathrm{x}$ daltons. \\
\hline P-gp & Glicoproteína P. \\
\hline PLA & Polilactato. \\
\hline PLGA x:y & $\begin{array}{l}\text { Poli(D, L-lactato-co-glicolato) com proporção de x\% de Lactato e } \\
\text { y\% Glicolato na formação copolimérica. }\end{array}$ \\
\hline PSE de Lenth & Pseudoerro de Lenth. \\
\hline SFB & Soro fetal bovino. \\
\hline SH-SY5Y & Linhagem de neuroblastoma humano (ATCC $\AA$ CRL-266 ${ }^{\mathrm{TM}}$ ). \\
\hline SNC & Sistema nervoso central. \\
\hline $\mathrm{T}-80$ & Polissorbato-80, Tween-80. \\
\hline$t-P A$ & Ativador de plasminogênio tecidual. \\
\hline Transf-Abm & Anticorpo monoclonal anti-transferrina. \\
\hline UNIFESP & Universidade Federal de São Paulo. \\
\hline USP & Padronização referente à U.S. Pharmacopeial Convention. \\
\hline
\end{tabular}




\section{LISTA DE SÍMBOLOS}

\begin{tabular}{|c|c|}
\hline Símbolo & Significado \\
\hline (h:min:s) & Grandezas de tamanho (hora:minuto:segundo). \\
\hline$\overline{A b s}_{b}$ & Absorbância média dos elementros brancos. \\
\hline$\overline{A b s}_{c}$ & Absorbância média dos elementos controle. \\
\hline$A b s_{i, t}$ & Absorbância do elemento $i$ da avaliação temporal $t$. \\
\hline$A b s_{i}$ & Absorbância do elemento $i$. \\
\hline${ }^{\circ} \mathrm{C}$ & Graus celsius. \\
\hline $\mathrm{CL}$ & Depuração (clearance). \\
\hline $\mathrm{CO}_{2}$ & Dióxido de carbono. \\
\hline$F$ & Variável da distribuição de Snedecor. \\
\hline$G$ & Aceleração da gravidade $9,8 \mathrm{~m} / \mathrm{s}^{2}$. \\
\hline $\mathrm{G}$ & Grama (e submúltiplos). \\
\hline $\mathrm{IC}_{50}$ & Concentração inibitória média. \\
\hline $\mathrm{IC}_{50, \mathrm{t}}$ & Concentração inibitória média para a averiguação temporal $t$. \\
\hline $\mathrm{L}$ & Litro (e submúltiplos). \\
\hline M & Metro (e seus submúltiplos). \\
\hline $\mathrm{m} / \mathrm{v}$ & Proporção massa:volume. \\
\hline$N$ & Tamanho amostral. \\
\hline$p^{x}$ & $\begin{array}{l}\text { Probabilidade para análise estatística, sendo } x \text { para a } \\
\text { averiguação de uma comparação específica. }\end{array}$ \\
\hline$R^{2}$ adj & Coenficiente de determinação ajustado. \\
\hline Rpm & Rotações por minuto. \\
\hline$T$ & Variável da distribuição de Student. \\
\hline$t_{1 / 2}$ & Tempo de meia-vida. \\
\hline $\mathrm{T}_{\mathrm{m}}$ & Temperatura de transição do lipídeo. \\
\hline $\mathrm{T}_{\mathrm{m}, \mathrm{x}}$ & Temperatura de transição do lipídeo $x$. \\
\hline V & Volt (considerando múltiplos e submúltiplos). \\
\hline $\mathrm{v} / \mathrm{v}$ & Proporção volume:volume. \\
\hline $\mathrm{V}_{\mathrm{D}}$ & Volume de distribuição. \\
\hline Z & Letra grega zeta. \\
\hline
\end{tabular}




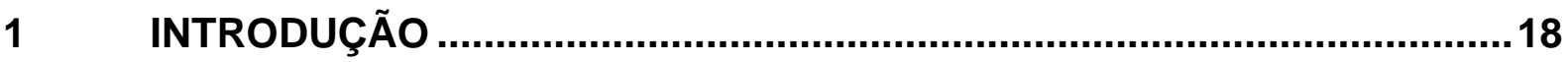

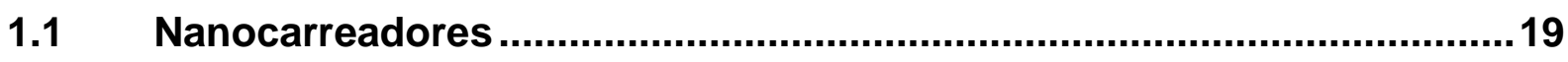

1.2 Estratégias de transposição da barreira hematoencefálica por

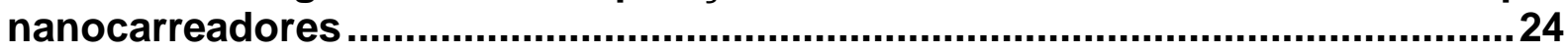

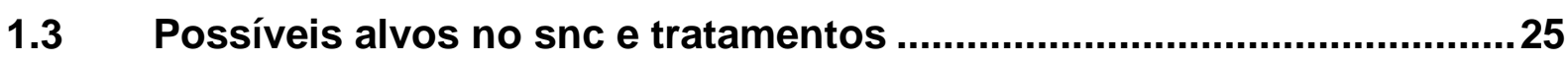

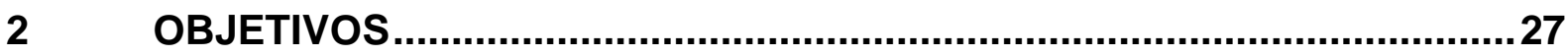

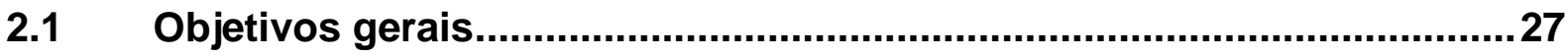

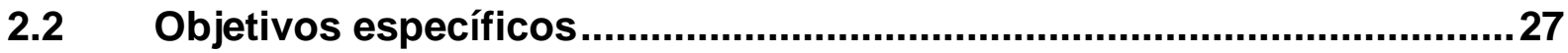

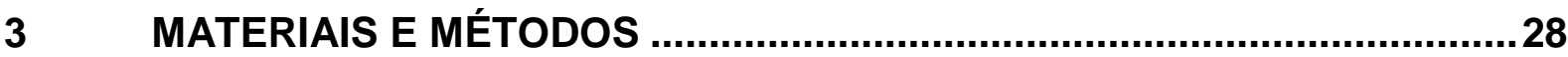

3.1 Reagentes empregados nos experimentos ...........................................28

3.2 Confecção de nanopartículas vazias (NPs) e com FITC (FITC-NPs) ......28

3.3 Caracterização de nanopartículas e comparação dos tensoativos DDAB e DMAB para otimização da síntese dos particulados .........................................30

3.4 Confeccção de lipossomos vazios (LPs) e com FITC (FITC-LPs) ...........31

3.5 Caracterização de lipossomos constituidos por DPPC e DOPC e otimização de seu processo de síntese ...............................................................

3.6 Avaliação da citotoxicidade de nanopartículas e lipossomos vazios em

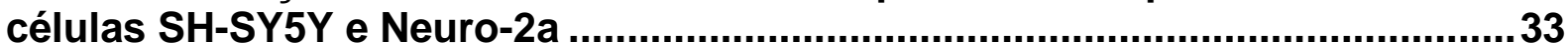

3.6.1 Cultivo de células imortalizadas de neuroblastoma humano SH-SY5Y e

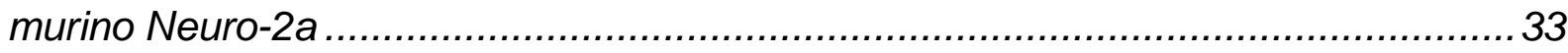

3.6.2 Padronização do ensaio de viabilidade celular do mtt em células de neuroblastoma humano SH-SY5Y e murino Neuro-2a ......................................... 33

3.6.3 Realização dos testes de citotoxicidade de nanopartículas e lipossomos nas linhagens neuronais.

3.7 Estudo do efeito dos carreadores sobre a entrega intracelular de um composto em células Neuro-2a e SH-SY5Y ..........................................................35

3.8 Análise de dados e tratamento estatístico empregados nos resultados obtidos. 36

4

RESULTADOS .38

4.1 Caracterização de nanopartículas vazias (NPs) e encapsuladas com FITC (FITC-NPs) e avaliação de seu processo de síntese 38

4.1.1 Teste fatorial $2^{2}$ para padronização do processo de confecção de nanopartículas vazias

4.1.2 Avaliação dos parâmetros de nanopartículas vazias nas etapas do seu

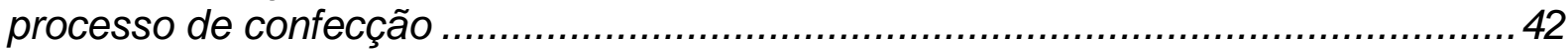

4.1.3 Comparação entre o emprego dos tensoativos DDAB e DMAB na síntese de NPS

4.1.4 Características de nanopartículas obtidas pelo processo selecionado 
4.1.5 Caracterização de nanopartículas conjugadas à fluorescina isotiocianato isômero I (FITC-NPS) ................................................................................. 47

4.2 Caracterização de lipossomos constituidos por DPPC e DOPC e otimização de seu processo de síntese ...............................................................49

4.2.1 Avaliação da cinética de formação de lipossomos vazios de DPPC e DOPC.. 49

4.2.2 Avaliação dos parâmetros de lipossomos vazios em etapas de síntese ......50

4.2.3 Avaliação do procedimento de centrifugação branda em lipossomos feitos com DOPC (DOPC-LPS) e DPPC (DPPC-LPS). 52

4.2.4 Caracterização de lipossomos conjugados à fluorescina isotiocianato isômero I (FITC-LPS)

4.3 Avaliação da citotoxicidade das formulações de nanopartículas e de lipossomos vazios em cultura de células SH-SY5Y ...........................................55

4.3.1 Padronização do teste de viabilidade celular com a aplicação de MTT em células SH-SY5Y e Neuro-2a. .56

4.3.2 Ensaios de citotoxicidade com a formulação de nanopartículas e imunolipossomos vazios

4.4 Estudo do efeito dos carreadores sobre a entrega intracelular de um composto em células Neuro-2a e SH-SY5Y .........................................................61

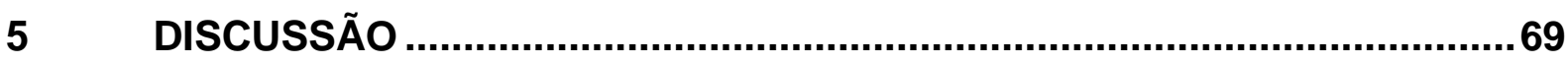

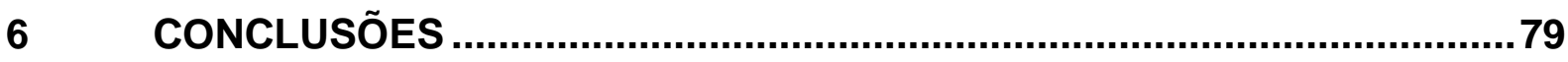

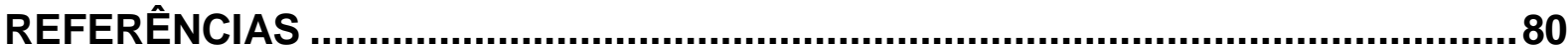




\section{INTRODUÇÃO}

A barreira hematoencefálica (BHE) é considerada uma das barreiras biológicas de maior dificuldade de transposição, o que dificulta significativamente o tratamento de doenças que atingem o sistema nervoso central.

A BHE consiste numa barreira difusional formada por três elementos da microvasculatura cerebral: células endoteliais, as extremidades dos prolongamentos dos astrócitos e os pericitos, considerados células-tronco multipotentes mesenquimais. A estrutura da BHE forma junções oclusivas que limitam a passagem de substâncias para o sistema nervoso central (SNC) (BALLABH et al., 2004; GREENHALGH et al., 2011). Embora exista tal restrição de transporte pela BHE, o SNC apresenta grande demanda de energia e nutrientes. Assim, diversas substâncias necessitam transpor a barreira, quer por transcitose adsortiva, transporte mediado por transportadores e receptores ou até mesmo por difusão passiva (GRABRUCKER et al., 2016).

Grande parte destes compostos, como os hidrofílicos, acabam sendo transportados ao SNC por meio de transportadores, como é o caso da glicose, cujo transportador de glicose do tipo 1 (GLUT1) medeia seu transporte, juntamente com o de outras hexoses (PARDRIDGE et al., 1990). Ademais, a BHE não apresenta apenas transportadores de influxo, mas também apresenta os transportadores de efluxo, tal como a glicoproteína $\mathrm{P}(\mathrm{P}$-gp) transcrita a partir do gene de multirresistência a fármacos (MDR1, multidrug resistance gene 1), a qual está diretamente associada com a baixa eficácia de muitos fármacos no SNC (SCHINKEL, 1999). Substâncias endógenas também podem ser transportadas por receptores peptídicos, como o receptor de insulina e o de transferrina localizados na BHE (PARDRIDGE et al., 1985; 1987). O receptor de transferrina, neste caso, permite a passagem de ferro ao SNC por estar associado ao processo endocitótico do complexo transferrina-ferro. Um outro mecanismo de transposição da BHE é o da endocitose adsortiva, um processo desencadeado pela interação entre um ligante e a superfície celular. A endocitose adsortiva pode ter origem eletrostática, pela interação da membrana celular negativamente carregada com ligantes positivamente carregados. A interação resulta 
na transcitose adsortiva do ligante, normalmente uma endocitose clatrina-depente (VILLEGAS; BROADWELL, 1993).

Considerando o número de doenças que atingem o sistema nervoso central e a dificuldade de fármacos em transpor a $\mathrm{BHE}$, diversas alternativas vêm sendo estudadas para vencer esta barreira (PARDRIDGE, 2012). A nanotecnologia traz inúmeras formas de entrega de fármacos, inclusive através da BHE. A nanotecnologia, ou nanociência, se refere ao estudo de elementos que possuam ao mínimo uma de suas dimensões menor ou igual a $100 \mathrm{~nm}$, embora não haja consenso quanto a este limite de tamanho dos produtos nanotecnológicos (ISO, 2008b). O próprio FDA (Food and Drug Administration) considera que os dispositivos nanotecnológicos podem ser considerados dentro da faixa 1 a 1.000 nm (FDA, 2014). Não obstante, a nanotecnologia não abrange uma área específica, mas desde a ciência dos materiais até o desenvolvimento de produtos de higiene pessoal. A nanomedicina, uma importante área da nanotecnologia, aborda o uso de sistemas que interferem a nível molecular para o tratamento, prevenção ou diagnóstico de doenças (PARK, 2007). Há grande diversidade de sistemas de carreamento, tais como lipossomos, micelas, nanocápsulas, dendrímeros, nanoesferas e nanotubos (BITOUNIS et al., 2012; CAMPOS, 2013). O presente trabalho visa avaliar o processo de obtenção, otimizar a síntese, desenvolver e caracterizar físico, químico e biologicamente nanocarreadores com a capacidade de acessar células do sistema nervoso central.

\subsection{Nanocarreadores}

Os lipossomos (Figura 1A) podem ser definidos como vesículas em que no mínimo uma dupla camada de fosfolipídeos circunda um volume aquoso (SCHNYDER; HUWYLER, 2005). Sua superfície é frequentemente modificada com polietilenoglicol (PEG), com o intuito de diminuir sua depuração sistêmica e inibir sua remoção por macrófagos do sistema reticuloendotelial. Tais lipossomos que passam pelo recobrimento com PEG são denominados como estericamente estabilizados (ALLEN; CHONN, 1987; PAPAHADJOPOULOS et al., 1991). Modificações quanto à farmacocinética de lipossomos estericamente estabilizados são claras, uma vez que lipossomos peguilados podem apresentar um volume de distribuição $\left(V_{D}\right)$ de até cinquenta vezes maior e uma depuração sistêmica $(C L)$ duzentas vezes menor, 
resultando em uma meia-vida ( $\left.t_{1 / 2}\right)$ em humanos próxima de noventa horas (ALLEN, 1994). Tais formulações são geralmente consideradas seguras para aplicações tanto em animais quanto em humanos (GABIZON et al., 2003).

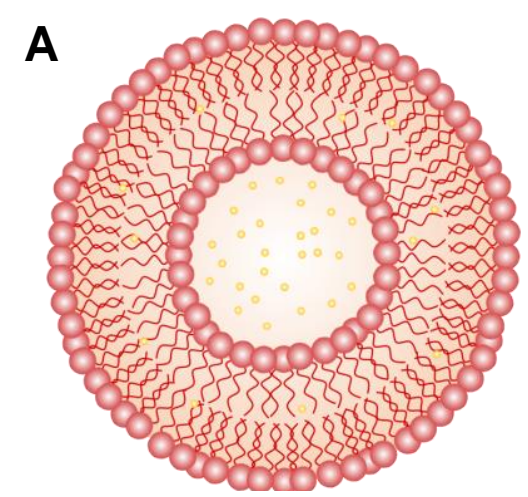

B

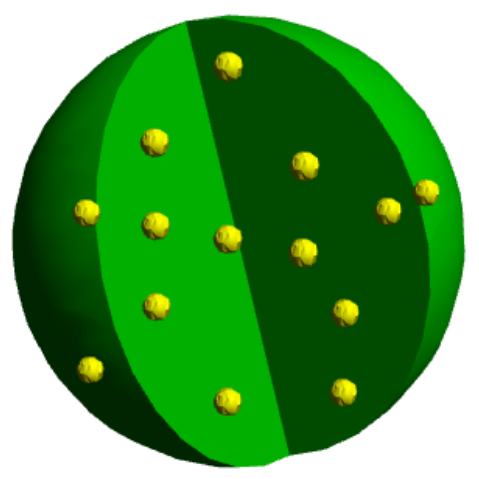

C

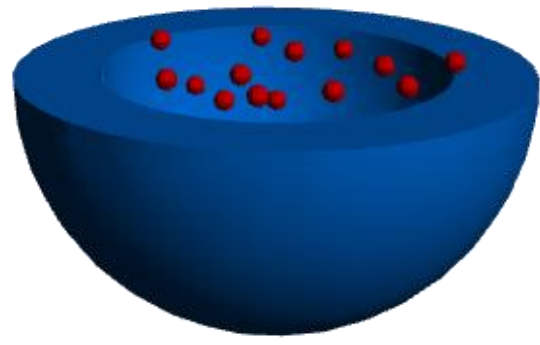

Figura 1 - Representações para lipossomos (A) e nanopartículas, sejam elas nanoesferas (B) ou nanocápsulas $(\mathrm{C})$.

Uma enorme variedade de lipídeos pode ser utilizada para sintetizar lipossomos com características específicas. Pode-se, por exemplo, fazer uso de lipídeos catiônicos, como o DOTAP (dioleiltrimetilamônio propano), para constituir sistemas de entrega de ácidos nucleicos, os quais são carregados negativamente (CIANI et al., 2007). Dentre tais lipídeos, as fosfatidilcolinas apresentam funções extremamente versáteis. Fosfatidilcolinas são glicerofosfolipídeos em que a colina está associada ao grupo fosfato, sendo tais lipídeos os mais abundantes nas células eucarióticas. Ademais as fosfatidilcolinas mais estudadas são a dipalmitoilfosfatidilcolina (DPPC) e a dioleilfosfatidilcolina (DOPC). A estrutura distinta de tais fosfatidilcolinas resulta em diferentes propriedades físico-químicas que modificam os aspectos como estabilidade e permeabilidade da bicamada lipossomal (ATTWOOD et al., 2013). A DPPC apresenta dois grupos palmitoil, de 16 carbonos, ao passo que DOPC apresenta dois 
grupos oleil, caracterizado por apresentar 18 carbonos e uma insaturação no carbono 9 (Figura 2).

A

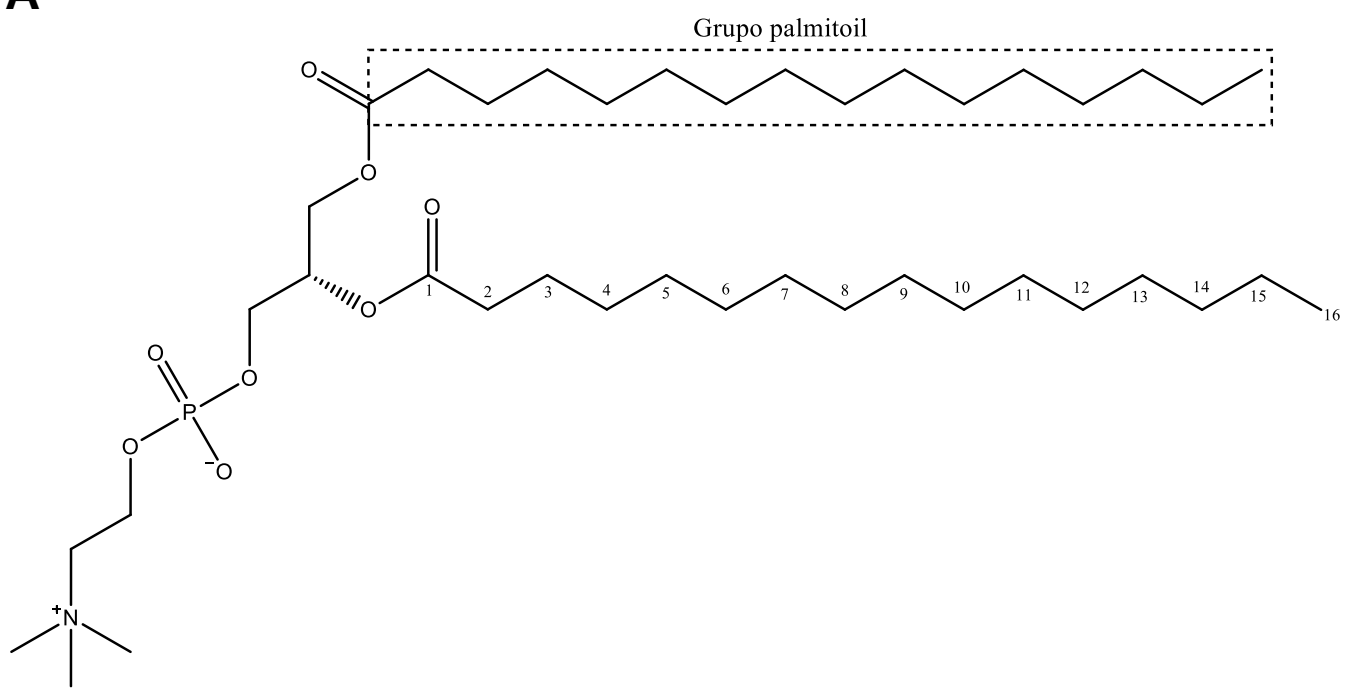

B

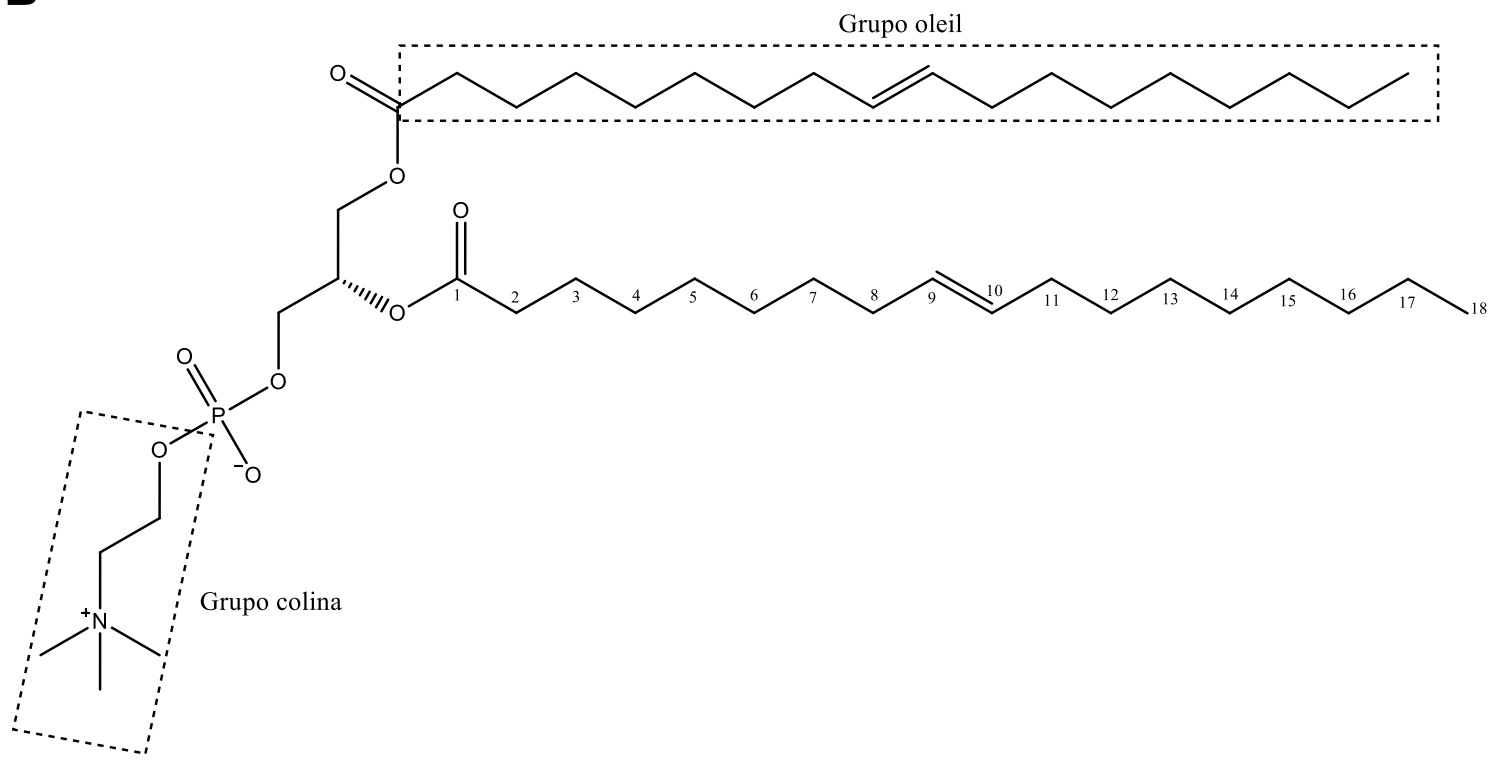

Figura 2 - Fórmulas estruturais da DPPC (A) e da DOPC (B). As fosfatidilcolinas são glicerofosfolipídeos, em que um dos grupamentos apresenta o grupo fosfato associado à colina. Os outros dois grupamentos na DPPC e DOPC são substituídos por grupos palmitoil e oleil, respectivamente.

De modo a garantir um sítio-direcionamento, lipossomos estericamente estabilizados podem ser conjugados a vetores, como proteínas, peptídeos e pequenas moléculas. Aplicações envolvendo lipossomos e imunolipossomos já se encontram em testes pré-clínicos e clínicos, bem como fármacos em formulações lipossomais já estão inseridos no mercado e são considerados respeitáveis sucessos clínicos (FAN; ZHANG, 2013). Uma série de ensaios clínicos verifica o potencial de diversos sistemas 
lipossomais para casos como Doença de Alzheimer; cânceres de mama, de ovário, de cólon, gliomas, melanomas, neuroblastomas ortotópicos, sarcomas de Kaposi, linfomas malignos; amenização dos efeitos de infecções e inflamações; dentre outros. (ALLEN; CULLIS, 2013; MANJAPPA et al., 2011; MATSUMURA et al., 2004; ROTMAN et al., 2015; SUZUKI et al., 2008).

Quanto aos fármacos encapsulados nestas formulações lipossomais, deve-se evidenciar que grande enfoque tem sido dado aos fármacos antineoplásicos e antibacterianos. O Doxil ${ }^{\circledR}$, o Myocet $^{\circledR}$ e o Lipo-dox ${ }^{\circledR}$ são exemplos de formulações lipossomais contendo doxorrubicina, uma antraciclina, e já estão disponíveis no mercado (BARENHOLZ, 2012; CHOU et al., 2006; LEONARD et al., 2009). Já é comercializado também o Ambisome ${ }^{\circledR}$, uma formulação de lipossomos contendo o antifúngico anfotericina B (MEUNIER et al., 1991). Por outro lado, certas formulações ainda passam por testes clínicos, a exemplo do EndoTAG $^{{ }_{-}}{ }^{-1}$ (estudo fase II) e a Lipoplatina $^{\circledR}$ (estudo fase III) contedo formulações lipossomais com paclitaxel e cisplatina, respectivamente (FANTINI et al., 2010; FASOL et al., 2012). A amicacina, um antibacteriano, também já foi encapsulada em lipossomos e esta formulação encontra-se em estudo fase III sob a marca Arikace ${ }^{\circledR}$ (LI et al., 2008).

Na outra vertente, nanopartículas (NPs) (Figura 1B, C) são partículas coloidais de tamanho da ordem de nanômetros formadas por emaranhados poliméricos, como poli(D, L-lactato-co-glicolato) (PLGA, poly D, L-lactide-co-glycolide acid), um material biocompatível e biodegradável e polilactatos (PLA, polylactides). O PLGA sofre metabolização lenta no organismo, formando os monômeros de ácidos láctico e glicólico, os quais são metabolizados de acordo com o ciclo do ácido cítrico (PANYAM; LABHASETWAR, 2003). Testes de toxicidade revelam segurança em uso de animais de experimentação e a aplicação do copolímero foi aprovada pelo FDA para sistemas de entrega de fármacos (LU et al., 2009; SEMETE et al., 2010).

O fármaco que foi encapsulado na nanopartícula acaba sendo liberado tanto por difusão quanto pela degradação do polímero, no entanto, no caso de NPs de PLGA, a composição copolimérica do mesmo pode ser modificada de modo a alterar sua biodegradação e modificar a taxa de liberação do fármaco (ANDERSON; SHIVE, 1997; LIN et al., 2000). Nanopartículas formadas por PLGA são normalmente formuladas dissolvendo o polímero em um solvente orgânico, o qual é emulsificado numa fase aquosa com um emulsificador. O solvente orgânico é posteriormente 
evaporado e a solução resultante contém os emaranhos poliméricos. Um emulsificador muito utilizado é o álcool polivinílico (PVA, polyvinyl alcohol), o qual proporciona a obtenção de partículas menores e mais uniformes e por ser uma substância mais fácil de ser dispersa no meio aquoso (JAIN, 2000). Não obstante, partículas que retêm menores quantidades de PVA acabam sendo melhor captadas por células-alvo (SAHOO et al., 2002). Por outro lado, o uso de brometo de didodecildimetilamônio (DMAB, didodecyldimethylammonium bromide) mostra-se altamente adequado como estabilizante de nanopartículas de PLGA, podendo resultar na formação de NPs de tamanho de até 108 nm (GOSSMANN et al., 2015). Outro potencial emulsificador é 0 brometo de didecildimetilamônio (DDAB, didecyldimethylammonium bromide), o qual auxilia na formação de partículas de até $90 \mathrm{~nm}$ (KUO; YU, 2011). A diferença entre os dois tensoativos é o tamanho das cadeias carbônicas: ao passo que o DDAB apresenta duas cadeias de 10 carbonos associadas ao cátio amônio quartenário, o DMAB possui cadeias de 12 carbonos (Figura 3).

A

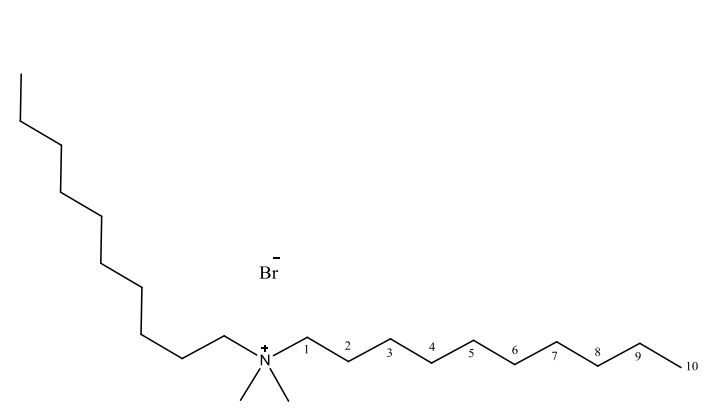

B

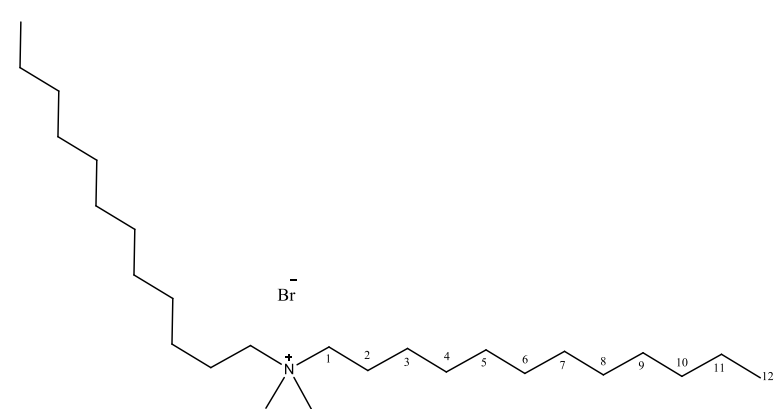

Figura 3 - O DDAB (A) e o DMAB (B) são sais de âmonio quartenário com o brometo, em que existe uma diferença do tamanho da cadeia carbônica entre os tensoativos. DDAB apresenta duas $\mathrm{C}_{10} \mathrm{e}$ DMAB apresenta duas $\mathrm{C}_{12}$.

As nanopartículas também podem ser aplicadas em inúmeras terapias. Os possíveis usos recaem em neoplasias como melanomas, tumores hepáticos e prostáticos, glioblastoma, bem como no imageamento de cânceres e isquemias (CHANG et al., 2012; LIU et al., 2013; MDZINARISHVILI et al., 2013; MEYERS et al., 2013; WOHLFART et al., 2010).

Até o momento, não há sistemas nanoparticulados poliméricos com fármaco encapsulado disponíveis no mercado, embora nanopartículas de ouro ou de soro fetal 
humano possam ser utilizadas para fins de diagnósticos (GOMMANS et al., 2009; LEFFERTS et al., 2009). No entanto, há uma série de sistemas de nanopartículas poliméricas sendo avaliadas em testes clínicos. Citam-se o CRLX101, em Fase II, contendo camptotecina; o BIND-014, em Fase II, que carreia docetaxel; e o BA-018, em Fase I, com irinotecano encapsulado. Destaca-se que estes três sistemas citados são compostos por fármacos antineoplásicos (HEIDEL; DAVIS, 2011; MORROW et al., 2007; SANNA; SECHI, 2012).

Desta forma, verifica-se que nanocarreadores, tais como nanopartículas poliméricas e lipossomos, podem ser direcionados à terapêutica de diversas doenças, inclusive as associadas ao SNC, uma vez que podem ser funcionalizados para transpor a BHE.

\subsection{Estratégias de transposição da barreira hematoencefálica por nanocarreadores \\ Nanopartículas podem ser recobertas com diversos agentes que facilitem a} adsorção nas barreiras do organismo. Um exemplo é o recobrimento de nanopartículas com polissorbato-80 (Tween-80 ou T-80), o que facilita a captação das partículas pelos capilares endoteliais de células encefálicas, conforme demonstrou estudo de Ramge e colaboradores (2000). Neste trabalho, desenvolvido em modelo in vitro com células humanas obtidas por autópsia, nanopartículas recobertas por T80 apresentaram captação mais rápida e 20 vezes maior que as não-tratadas pelo endotélio cerebral, por meio de um mecanismo endocitótico, ainda não totalmente elucidado (RAMGE, 2000; TAHARA et al., 2010).

O direcionamento de nanocarreadores também pode ser obtido com a incorporação de anticorpos monoclonais, de modo a dirigir a entrega do fármaco encapsulado (PANYAM; LABHASETWAR, 2003). É pertinente dizer que o direcionamento pode ser tanto ativo, quando a incorporação do agente terapêutico é feita a um ligante tecido- ou célula-específico (LAMPRECHT et al., 2001); quanto passivo, quando o nanocarreador se acumula em determinado local, normalmente devido a condições patológicas, como na angiogênese associada a neoplasias (MONSKY et al., 1999). 
Lipossomos também podem ter diversos vetores incorporados para transpor a BHE. Peptídeos, proteínas modificadas ou anticorpos podem promover a transcitose mediada por receptores ou por absorção, possibilitando a passagem da vesícula pela barreira. São comuns as utilizações de vetores como o anticorpo monoclonal ao receptor de insulina, o anticorpo monoclonal OX26 do receptor de transferrina de rato, a albumina cationizada, dentre outros (PARDRIDGE, 2005; WU; PARDRIDGE, 1997). O lipossomo associado a um anticorpo adquire a denominação de imunolipossomo.

\subsection{Possíveis alvos no SNC e tratamentos}

Os processos neurodegenerativos envolvem a perda crônica e progressiva de forma seletiva e, por vezes, simétrica de neurônios dos sistemas motor, sensorial ou cognitivo (MARTIN, 1999). A neurodegeneração está diretamente associada com o desequilíbrio gradual do padrão homeostático oxirredutivo, evoluindo para determinadas doenças como a Doença de Huntington (DH), Doença de Alzheimer (DA), Doença de Parkinson (DP), epilepsias e crises convulsivas (COBB; COLE, 2015). A morte neuronal também pode ocorrer por isquemia ou danos decorrentes ao trauma. A grande questão na morte neuronal é que a maioria da população de neurônios em um ser humano adulto são pós-mitóticos (FRADE; OVEJERO-BENITO, 2015). Portanto, a capacidade de renovação do tecido lesado é insuficiente para suprir a necessidade do organismo. Ademais, poucas são as regiões que evidenciam a capacidade de proliferação, como a subventricular e a do giro denteado hipocampal (DOETSCH et al., 1999; ERIKSSON et al., 1998).

De forma geral, inúmeros são os mecanismos envolvidos na morte neuronal. Certas doenças neurodegenerativas apresentam mecanismos específicos, mas a isquemia, por outro lado, envolve inúmeros eventos concomitantes que acarretam na morte do neurônio (MEHTA et al., 2007). Neurônios podem morrer nestes contextos por necrose, frente ao estresse celular, em que o desbalanço osmótico e a depleção energética causam a lise da célula; ou por apoptose, em que neurônios modestamente afetados pelo contexto lesivo são induzidos a uma morte programada (JELLINGER, 2001).

É importante destacar que o dano cerebral decorrente da isquemia cerebral focal ou global é uma grande causa de mortalidade e morbidade no mundo (WAGNER, 
2007). Não existe nenhum fármaco no mercado sabidamente eficaz para o tratamento de pacientes vítimas de isquemias instaladas derivadas do acidente vascular cerebral (AVC) agudo ou de paradas cadíacas. No entanto, o uso do ativador de plasminogênio tecidual (t-PA), administrado até três horas após o estabelecimento dos sintomas, tem auxiliado na recuperação dos pacientes (HACKE et al., 2004). É necessário ressaltar que a busca por outros tipos de terapias para neuroproteção se faz, então, essencial. Além da isquemia cerebral, diversas doenças neurodegenerativas ainda não apresentam tratamento eficiente. A Doença de Alzheimer (DA), a Doença de Parkinson (DP) e a esclerose múltipla são exemplos.

No caso da DP, por exemplo, a produção central de dopamina é debilitada por uma degeneração progressiva de regiões do SNC ricas em neurônios dopaminérgicos resultanto, primeiramente, em alterações motoras e, com o avanço da doença, em complicações mentais e emocionais (THOMAS; BEAL, 2007). Há de se considerar que, apesar de a dopamina não transpor a BHE, fármacos como a L-DOPA (L-3,4-diidroxifenilalanina), embora ineficientes em casos severos da doença, são regularmente aplicados. Ademais, muitos dos fármacos para tratamento da DP disponíveis no mercado apresentam efeitos adversos, como discinesia e refratariedade. $\mathrm{O}$ uso de sistemas que transpõem a BHE introduz uma ferramenta versátil, possibilitando o emprego de fármacos com melhores especificidades terapêuticas (PAHUJA et al., 2015).

As epilepsias, por sua vez, consistem em diversas apresentações clínicas, com eventual presença de crises (epilépticas) espontâneas, ou não, e recorrentes (MUKHOPADHYAY, 2012). A problemática no tratamento farmacológico das epilepsias é que muitas síndromes são refratárias ao uso dos fármacos disponíveis no mercado e acredita-se que este fato decorra da dificuldade destes em transpor a BHE (BENNEWITZ; SALTZMAN, 2009).

Dada a relevância da utilização de nanocarreadores funcionalizados, podemos compreender que estes sistemas nanoparticulados poliméricos e lipossomais possuem uma potencial vantagem de ação no sistema nervoso central de modo a liberar compostos de interesse de maneira sítio-específica e assim, contribuindo na terapia de diversas doenças. 


\section{OBJETIVOS}

\subsection{Objetivos gerais}

- O presente trabalho visa otimizar a síntese, confeccionar e caracterizar sistemas nanoparticulados poliméricos e lipossomais cujas funcionalizações os associam a aplicações no Sistema Nervoso Central.

\subsection{Objetivos específicos}

- Avaliar parâmetros de produção na síntese de nanoparticulados poliméricos e lipossomais;

- Comparar o efeito de tensoativos na formação de nanopartículas e de fosfatidilcolinas na de lipossomos;

- Investigar a citotoxicidade e a internalização de tais nanocarreadores em células neuronais das linhagens Neuro-2a (ATCC $\AA_{\text {CCL-131 }}^{\mathrm{TM}}$, N2a) e/ou SH-SY5Y (ATCC ${ }^{\circledR}$ CRL-2266 ${ }^{\mathrm{TM}}$ ), como testes biológicos. 


\section{MATERIAIS E MÉTODOS}

\subsection{Reagentes empregados nos experimentos}

PLGA 50:50, DMAB, DDAB, FITC, Acetato de etila (HPLC), MTT e o anticorpo monoclonal anti- $\beta$-actina confeccionado em camundongos foram adquiridos da Sigma-Aldrich. O anticorpo anti-pan-caderina produzido em cabra foi obtido da Santa Cruz. DPPC, DOPC, Colesterol, DSPE-PEG ${ }^{2000}$, DSPE-PEG ${ }^{2000}-M a l$ (Avanti Lipids) e o anticorpo anti-transferrina confeccinado em camundongo (Bio X-cell) foram cedidos gentilmente pelo Professor Gehrard Wunderlich. Tween-80 USP foi adquirido da Synth e DMEM pela Vitrocell.

\subsection{Confecção de nanopartículas vazias (NPs) e com FITC (FITC-NPs)}

As nanopartículas foram confeccionadas pelo método de emulsificação em óleo-água. Para a síntese de nanopartículas vazias, dissolveram-se $50 \mathrm{mg}$ de poli(D,L-lactato-co-glicolato) (PLGA) 50:50 em 2,5 mL de acetato de etila (AcEt) e 50 mg de tensoativo, quer brometo de didodecildimetilamônio (DMAB) ou brometo de didecildimetilamônio (DDAB) em $5,0 \mathrm{~mL}$ de água destilada. Gotejou-se lentamente a solução de PLGA na de tensoativo sob vigorosa agitação, submetendo-se a emulsão resultante ao processo de sonicação (sonicador de haste SONICS, modelo CV334) em regime de 5 pulsos de 50 s ou 30 s espaçados por intervalos de 30 s sem sonicação; todo este procedimento realizado em banho de gelo. Em sequência, deixou-se a mistura em agitação overnight para evaporação do solvente orgânico. Passado tal período, centrifugou-se a solução por 25 minutos, $4^{\circ} \mathrm{C}$ e a $17.000 \mathrm{~g}$, para se retirar o sobrenadante e ressuspender o pellet formado com 1 ou $2 \mathrm{~mL}$ de uma solução de Tween-80 4\% (v/v, T-80) em água destilada. A incorporação do T-80 foi realizada com agitação por $1 \mathrm{~h}$ utilizando uma barra magnética, cujo tamanho foi avaliado, sendo que após, nova centrifugação foi realizada, nos mesmos parâmetros que os anteriormente citados, para a remoção do excesso de T-80. A ressuspensão do pellet de nanopartículas, neste caso, foi realizada com $1 \mathrm{~mL}$ de água destilada. $A$ Figura 4 ilustra o fluxograma de síntese das nanopartículas poliméricas. 


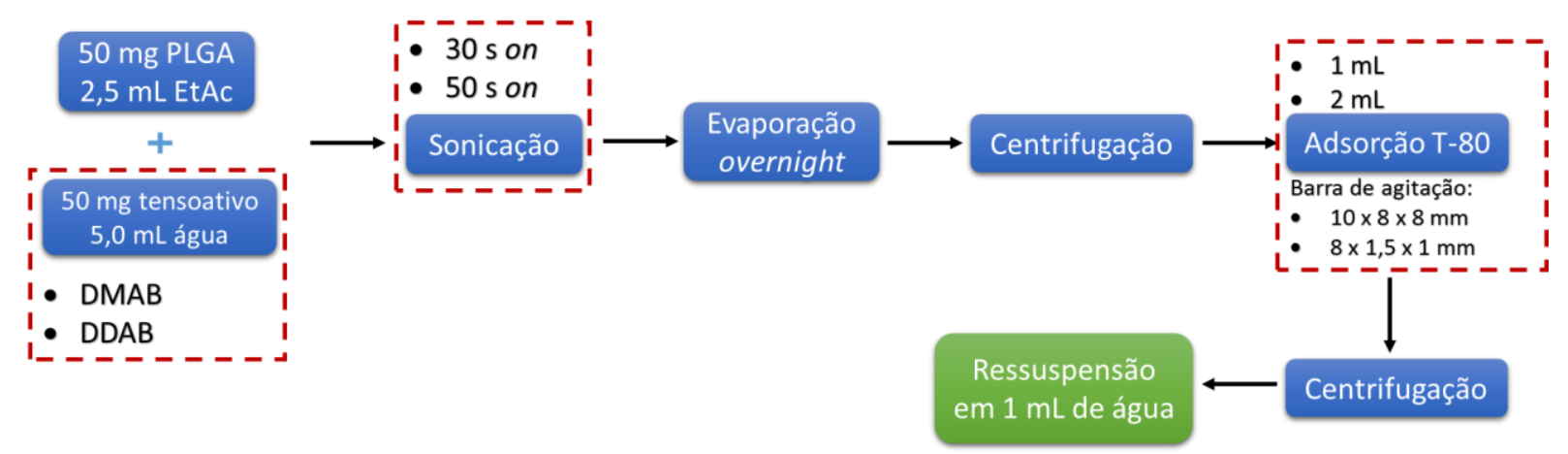

Figura 4 - Fluxograma do processo de confecção de nanopartículas poliméricas. As caixas azuis ilustram as etapas intermediárias e a verde a etapa final. As caixas vermelhas indicam etapas que tiveram variáveis modificadas para otimização do processo.

Verificou-se que o processo de ressuspensão de nanopartículas em T-80 consistia num processo crítico para a formação de aglomerados poliméricos; portanto realizou-se um teste fatorial $2^{2}$ nesta etapa, em que se avaliaram as variáveis volume de ressuspensão em T-80 (variável A) e o tamanho do agitador (variável B). O teste aborda dois subníveis por variável, no caso da variável $A$, abordou-se como maior subnível o volume de $2 \mathrm{~mL}$ para ressuspensão em T-80 (+) e o menor como sendo 1 $\mathrm{mL}(-)$. No caso da variável $\mathrm{B}$, o maior subnível foi representado por um barra magnética pequena de dimensões $10 \times 8 \times 8 \mathrm{~mm}(+)$ e o menor por um microagitador de $8 \times 1,5 \times 1 \mathrm{~mm}(-)$. O teste fatorial aborda a combinação de todos os subníveis de todas as variáveis para a investigação dos efeitos destas em diferentes variáveisresposta para otimização de processos em número reduzido de experimentos. Tais variáveis-resposta foram o tamanho e o potencial zeta das nanopartículas sintetizadas nos processos diferenciais. Desejavam-se partículas cujo tamanho fossem os menores possíveis e cujo potencial zeta fosse, em módulo, maior.

Nanopartículas encapsuladas com fluorescina isotiocianato isômero I (FITC) foram preparadas com leves modificações do processo acima relatado, uma vez que a FITC não se solubilizava totalmente em acetato de etila. Uma quantidade de $2 \mathrm{mg}$ de FITC foi solubilizada em uma solução de acetona:acetato de etila ( $53 \%$ de acetona $\mathrm{v} / \mathrm{v}$ ) e completada com acetato de etila suficiente para dissolver $50 \mathrm{mg}$ de PLGA, isto é, um volume final de 2,5 $\mathrm{mL}$ de solvente orgânico. As próximas etapas seguiram o protocolo padrão de síntese de nanopartículas vazias, tomando cautela do contato da solução com a luminosidade. Ademais, o período de agitação da solução de 
nanopartículas para a adsorção do T-80 foi diminuído para $10 \mathrm{~min}$, de modo a evitar difusão da FITC encapsulada para o meio dispersante.

\subsection{Caracterização de nanopartículas e comparação dos tensoativos DDAB e DMAB para otimização da síntese dos particulados}

Nanopartículas vazias ou encapsuladas com FITC, foram caracterizadas quanto ao diâmetro, índice de polidispersidade (PDI) e potencial zeta (ל). O PDI avalia a dispersão de tamanho dos particulados, uma vez que seus diâmetros não se apresentam uniformemente distribuídos, variando entre valores de 0,0 e 1,0. Amostras com PDI inferiores a 0,1 são consideradas monodispersas e valores acima de 0,7 indicam uma grande variabilidade de tamanho (HOLMKVIST et al., 2016; ISO, 2008a). O potencial zeta, por sua vez, consiste no potencial elétrico avaliado na superfície do particulado. Neste caso, a questão da estabilidade da formulação é avaliada, pois caso potenciais muito próximos de $0,0 \mathrm{mV}$ sejam mensurados, pode-se esperar maior tendência de formação de aglomerados; enquanto que a presença de potenciais superficias de $\pm 30,0 \mathrm{mV}$ indica uma menor incidência de tal ocorrência pela repulsão eletrostática (DUMAN; TUNÇ, 2009). O tamanho de particulados é medido pela técnica do espalhamento dinâmico de luz (DLS, Dynamic Light Scattering), ao passo que o potencial zeta é mensurando pela leitura da mobilidade eletroforética utilizando microeletroforese, ambos avaliados com o equipamento Zetasizer Nano ZS90 (Malvern).

O processo de síntese de nanopartículas foi caracterizado ao longo de cada uma de suas etapas pela avaliação do tamanho, PDI e potencial zeta dos particulados. Desejava-se avaliar se existiam melhores combinações de algum destes parâmetros pela realização de dois regimes distintos de sonicação: um de cinco pulsos de 30 segundos e outros de cinco pulsos de 50 segundos. As medições foram realizadas após a sonicação (etapa A); após o período overnight para evaporação do solvente orgânico (B); após a primeira centrifugação com controle aquoso (C); após a primeira centrifugação com a ressuspensão em T-80 (D); após o período de agitação de $1 \mathrm{~h}$ em T-80 (E); e após a nova centrifugação para remover o excesso de T-80 (F). Buscase não só avaliar o efeito diferencial dos dois tratamentos de sonicação, como também se há influência destes ao longo do processo de confecção das nanopartículas. 
Nanopartículas vazias, recobertas ou não com Tween-80 também foram avaliadas por microscopia eletrônica de varredura com emissão de campo (MEV-FEG) com a finalidade de se investigar forma, morfologia superficial e tamanho real dos particulados. As formulações foram aplicadas sobre lamínulas de borossilicato tratadas com poli-L-lisina. Após a secagem, as lamínulas foram removidas e coladas sobre um stub de alumínio, com posterior aplicação de cola condutiva de prata. O material foi então revestido com um filme de $25 \mathrm{~nm}$ de ouro sob pressão reduzida de $10^{-4}$ mbar com injeção de argônio; e corrente de $60 \mathrm{~mA}$ numa metalizadora Leica EM SCD500. As imagens foram realizadas no FEG (Field Emission Gun) FEI Quanta 250, utilizando os parâmetros: HV (High Vacuum), $30 \mathrm{kV}$, spotsize de 4,5 e 5,0 mm de distância de trabalho (WD, working distance,). O microscópio pertence ao Centro de Microscopia Eletrônica (CEME) da Universidade Federal de São Paulo (UNIFESP).

\subsection{Confeccção de lipossomos vazios (LPs) e com FITC (FITC-LPs)}

Lipossomos foram confeccionados pelo método de hidratação de filme lipídico. Uma mistura de fosfolipídeos contendo DPPC:CH:DSPE-PEG 2000 ou DOPC:CH:DSPE-PEG 2000 nas proporções molares de 4:1:0,2 foram dissolvidas em clorofórmio. Cada formulação de lipossomos foi sintetizada de modo que $1,00 \mathrm{mg}$ de fosfatidilcolina (DPPC ou DOPC) estivesse presente em $100 \mu \mathrm{L}$ de solução retirada para o tratamento. Na mistura de lipídeos, adicionou-se o equivalente a $5 \mu \mathrm{g}$ de DSPEPEG ${ }^{2000}-\mathrm{MAL}+$ (Transf-Abm), isto é, o lipídeo conjugado ao anticorpo monoclonal de anti-transferrina. A conjugação do anticorpo ao lipídeo se deu com o uso de 2iminotiolano (reagente de Traut) e posterior purificação numa coluna C8. Após o preparo da solução de lipídeos, realizou-se a evaporação do clorofórmio para formação do filme lipídico; assim, a mistura de fosfolipídeos foi posta sob agitação de 500 rpm por $2 \mathrm{~h}$ e a $37^{\circ} \mathrm{C}$ ou a vácuo por $1 \mathrm{~h}$ a $37^{\circ} \mathrm{C}$ para evaporação do solvente. O filme formado foi ressuspendido em solução salina de PBS, pH de 7,4 e deixado sob agitação vigorosa em temperatura acima daquela de transição da fosfatidilcolina, isto é, $60^{\circ} \mathrm{C}$ para o DPPC, ou $37^{\circ} \mathrm{C}$ para a DOPC. Terminado este procedimento, a mistura de lipossomos formados foi sonicada.

De forma a avaliar a cinética de formação de lipossomos de DPPC e DOPC, realizaram-se sucessivos pulsos de 30 segundos de sonicação até que sete ciclos 
fossem completos. Medições de tamanho e PDI dos lipossomos foram realizadas após cada pulso de sonicação, a fim de avaliar qual era o regime de sonicação que fornecia a melhor configuração de vesículas lipossomais. A dispersão foi centrifugada por 10 min a $5.000 \mathrm{rpm}$ na temperatura de $25^{\circ} \mathrm{C}$ para remoção de dióxido de titânio desprendido durante o processo de sonicação de haste (SKOCAJ et al., 2011).

Outro ensaio buscou investigar em lipossomos confeccionados a partir de DPPC se distintos métodos de evaporação do solvente orgânico, o clorofórmio, poderiam influir nos parâmetros dos lipossomos formados. Realizaram-se para tal dois tratamentos, uma evaporação rotatória a vácuo por $1 \mathrm{~h}$ a $37^{\circ} \mathrm{C}$ e outra evaporação gradual a $37{ }^{\circ} \mathrm{C}$ com agitação branda de 500 rpm. Os lipossomos tiveram seus parâmetros medidos após a sonicação da formulação; após o processo de filtração $(0,45 \mu \mathrm{m})$ e após uma centrifugação de $21.000 \mathrm{~g}$ a $4^{\circ} \mathrm{C}$ por $1 \mathrm{~h}$, em que se coletaram os lipossomos do sobrenadante. Ademais, avaliou-se se o processo de centrifugação para remoção de dióxido de titânio alteraria significantemente os parâmetros das vesículas presentes nas formulações. A Figura 5 sumariza o processo de síntese de lipossomos e as caracterizações realizadas.

Lipossomos encapsulados com FITC foram sintetizados com leves alterações no protocolo acima descrito. Lipossomos com FITC encapsulado foram feitos ressuspendendo o filme lipídico em $1 \mathrm{~mL}$ de uma solução de FITC em PBS 0,1 $\mathrm{mg} / \mathrm{mL}$. O processo foi realizado sob proteção do contato com a luz.

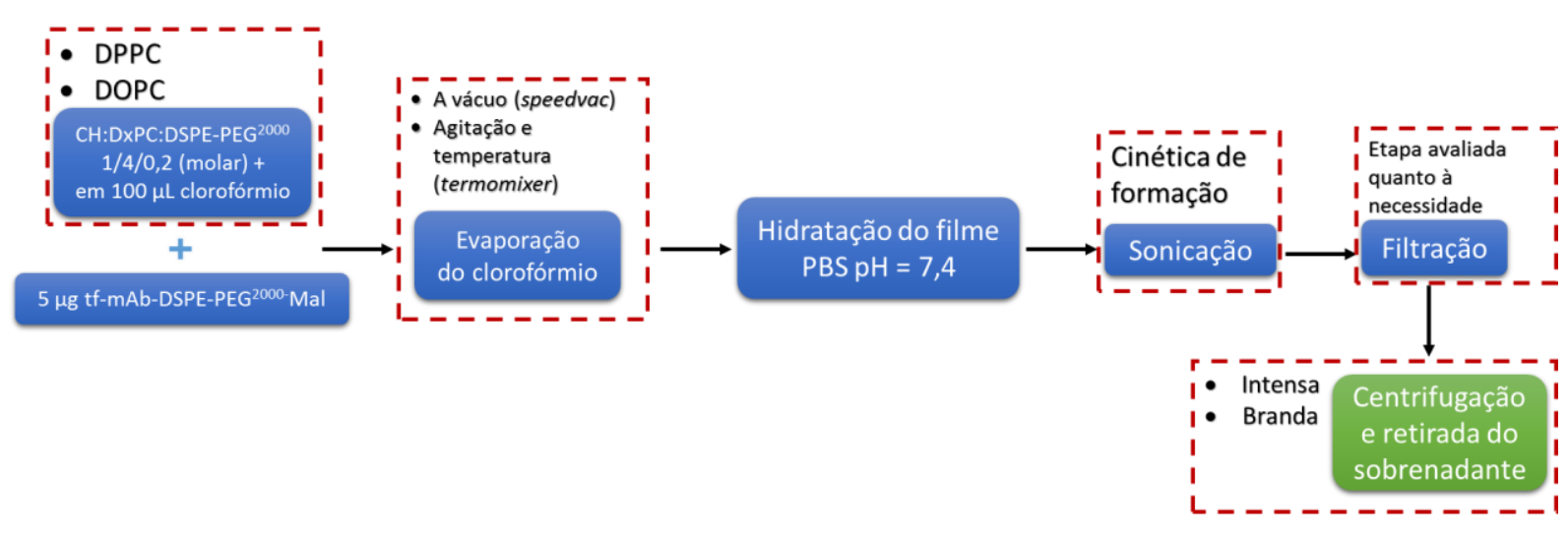

Figura 5 - Fluxograma do processo de confecção de lipossomos. As caixas azuis ilustram as etapas intermediárias e a verde a etapa final. As caixas vermelhas são referentes a etapas que tiveram variáveis modificadas para otimização do processo. 


\subsection{Caracterização de lipossomos constituidos por DPPC e DOPC e otimização de seu processo de síntese}

Similarmente ao caso das nanopartículas, cada um dos sistemas de lipossomos foi caracterizado quanto ao seu tamanho, PDI e potencial zeta. Neste grupo, incluemse os lipossomos vazios confeccionados com DPPC ou DOPC e os FITC-LPs.

\subsection{Avaliação da citotoxicidade de nanopartículas e lipossomos vazios em células SH-SY5Y e Neuro-2a}

3.6.1 Cultivo de células imortalizadas de neuroblastoma humano SH-SY5Y e murino Neuro-2a

As células da linhagem de neuroblastoma humano SH-SY5Y (ATCC® CRL$266^{\mathrm{TM}}$ ) e murino Neuro-2a (ATCC® CCL-131 ${ }^{\mathrm{TM}}$, N2a) foram cultivadas em meio de cultura DMEM (Dulbecco's Modified Eagle's Medium) suplementado com 10\% de soro fetal bovino (SFB) em frasco-T de $25 \mathrm{~cm}^{2}$ em incubadora à atmosfera úmida de $37^{\circ} \mathrm{C}$, $5,0 \%$ de $\mathrm{CO}_{2}$. As células foram cultivadas durante três passagens antes da realização de experimentos, de forma a se recuperarem do descongelamento e retomarem o crescimento celular habitual.

3.6.2 Padronização do ensaio de viabilidade celular do MTT em células de neuroblastoma Humano SH-SY5Y e murino Neuro-2a

O ensaio do MTT é um indicador da atividade metabólica celular, em que 0 brometo de 3-(4-5-dimetiltiazol-2-il)-2,5-difenil-tetrazólio (MTT) de cor amarela é clivado pela atividade mitocondrial à formazana, de cor púrpura, permitindo averiguar, desta forma, a viabilidade celular (BERRIDGE; TAN, 1993; MOSMANN, 1983). Células de neuroblastoma humano, SH-SY5Y, foram cultivadas em placas multipoços de 96 poços na densidade de $4 \times 10^{4}$ células/poço e aguardou-se um período de $24 \mathrm{~h}$ após o plaqueamento para o início do experimento. Como controle positivo do teste, $10 \mu \mathrm{L}$ de uma solução de Triton X-100 em PBS (9\% v/v) por $100 \mu \mathrm{L}$ de meio cultura foram aplicados. O Triton é um permeabilizador de membrana celular e, nesta concentração, causa a sua ruptura (KOLEY; BARD, 2010). Após a aplicação do Triton, as placas foram incubadas em atmosfera úmida de $5,0 \%$ de $\mathrm{CO}_{2}$ a $37^{\circ} \mathrm{C}$ por 45 minutos e prosseguiu-se para a aplicação de $10 \mu \mathrm{L}$ de uma solução de MTT em concentração de $5 \mathrm{mg} / \mathrm{mL}$ para cada $100 \mu \mathrm{L}$ de meio em cada poço da placa. A aplicação de MTT foi efetuada em espaçamentos de $20 \mathrm{~min}$, de modo a averiguar o 
padrão cinético da conversão do MTT à formazana em períodos de 20 min até $4 \mathrm{~h}$. Durante tais períodos, as placas foram incubadas em atmosfera úmida de $37^{\circ} \mathrm{C}$ e $5,0 \%$ de $\mathrm{CO}_{2}$. O meio de cultura foi então retirado e os cristais solubilizados em 120 $\mu \mathrm{L}$ de álcool isopropílico, seguido de agitação por $2 \mathrm{~min}$, a $500 \mathrm{rpm}$ e $37^{\circ} \mathrm{C}$ para homogeneização. A leitura de absorbância foi realizada no Multidetector Synergy ${ }^{\mathrm{TM}}$ HT (BioTek) em comprimento de onda de $570 \mathrm{~nm}$. A correção dos dados de absorbância foi realizada conforme a equação (1) abaixo:

$$
\text { Densidade óptica[U.A. }]=A b s_{i, t}-\overline{A b s}_{b}
$$

Em que $A b s_{i, t}$ é o valor de um dado valor de determinada replicata de absorbância obtido para um grupo temporal $t$; e $\overline{A b s}_{b}$ consiste na média dos valores de absorbância de medidas de branco, isto é, apenas com álcool isopropílico.

3.6.3 Realização dos testes de citotoxicidade de nanopartículas e lipossomos nas linhagens neuronais

As formulações vazias tanto de NPs, como LPs foram averiguadas quanto ao seu potencial citotóxico primeiramente em linhagem de células de neuroblastoma murino, N2a. As células foram cultivadas em placas multipoços de 96 poços na densidade de $4 \times 10^{4}$ células/poço e aguardou-se $24 \mathrm{~h}$ para o início do experimento. As formulações foram aplicadas nas proporções volumétricas (volume da formulação de nanocarreador/volume de meio de cultura) de 1:5, 1:25, 1:125, 1:625, 1:3125, 1:15625 e 1:78125 em meio de cultura nos tempos de $15 \mathrm{~h}$ e $24 \mathrm{~h}$. No caso de nanopartículas as formulações foram aplicadas na linhagem de células de neuroblastoma humano, SH-SY5Y nas proporções volumétricas de 1:5, 1:10, 1:20, 1:40, 1:80, 1:160 e 1:320 em meio de cultura nos tempos de $12 \mathrm{~h}$ e $24 \mathrm{~h}$. Como controles, utilizaram-se células não tratadas (controle negativo) e tratadas com Triton X-100 em PBS ( $9 \% \mathrm{v} / \mathrm{v}$, controle positivo). O MTT foi adicionado com seu tempo de incubação padronizado (1 h em SH-SY5Y ou 40 min em N2a). A conversão de dados de absorbância a valores de porcentuais de viabilidade celular foi realizada como exibido na equação (2):

$$
\text { Viabilidade }[\%]=\frac{A b s_{i}-\overline{A b s}_{b}}{\overline{A b s}_{c}-\overline{A b s}_{b}} \times 100
$$


em que $A b s_{i}$ é o valor de uma dada medida de absorbância; $\overline{A b s}_{b}$ consiste na média dos valores de absorbância de medidas de branco, isto é, apenas com álcool isopropílico; e $\overline{A b s}_{c}$ representa a média dos valores de absorbância dos controles negativos do ensaio.

\subsection{Estudo do efeito dos carreadores sobre a entrega intracelular de um composto em células Neuro-2a e SH-SY5Y \\ FITC-NPs, FITC-LPs, NPs e LPs foram confeccionados para se averiguar o} processo de internalização dos nanocarreadores e/ou de seu conteúdo em células Neuro-2a e SH-SY5Y. As células foram plaqueadas em placa multipoços de 24 poços com lamínulas de vidro de borossilicato, na densidade de $4 \times 10^{5}$ células/poço e deixadas sob cultivo por $24 \mathrm{~h}$. Os nanocarreadores foram aplicados em concentrações verificadas como não-citotóxicas, conforme verificado com o método de viabilidade do MTT, na cultura celular e as células incubadas em atmosfera úmida de $37^{\circ} \mathrm{C}$ e $5,0 \%$ de $\mathrm{CO}_{2}$ por 6, 12 e 24 h no caso de nanopartículas; e por 30 min, 6 h e 24 h para lipossomos. O meio de cada poço foi então drenado e $1 \mathrm{~mL}$ de solução salina a $4{ }^{\circ} \mathrm{C}$ de PBS estéril, $\mathrm{pH} 7,4$, foi adicionado a cada poço. Para a fixação das células à lamínula, utilizou-se $500 \mu \mathrm{L}$ de metanol a $-20{ }^{\circ} \mathrm{C}$ por poço, sendo que após tal aplicação, a placa foi vedada e deixada em repouso a $4{ }^{\circ} \mathrm{C}$ por $30 \mathrm{~min}$. O metanol foi então retirado e cada poço foi lavado três vezes por $10 \mathrm{~min}$ com $1 \mathrm{~mL}$ de PBS, seguido de uma lavagem por 5 minutos com solução de glicina em PBS $(7,5 \mathrm{mg} / \mathrm{mL}$ para favorecer a manutenção dos agentes de fluorescência) e uma lavagem por 5 minutos com PBS para retirar o excesso de glicina. Realizou-se o bloqueio para evitar inespecificidade de ligação no tratamento com anticorpos com uma solução de soro de jumento a 5\% e Triton X-100 a 0,05\% em PBS por $1 \mathrm{~h}$. Decorreu-se a aplicação do anticorpo primário, a qual foi realizada em solução de bloqueio diluída (solução de soro de jumento a 1\% e Triton X-100 a 0,01\% em PBS). Os anticorpos primários aplicados foram ora o anti-pan-caderina confeccinado em cabra (Santa Cruz) na diluição de 1:1.000 (v/v); ou o monoclonal anti- $\beta$-actina confeccionado em camundongos (Sigma-Aldrich) na diluição de 1:4.000 (v/v); ambos incubados por um período de $16 \mathrm{~h}$ na temperatura de $4^{\circ} \mathrm{C}$. Enquanto que as caderinas englobam uma família de glicoproteínas transmembranas associadas à adesão celular, a $\beta$-actina é uma das isoformas da actina, não estando presente na musculatura, assumindo ou a 
forma globular no citoplasma, ou a filamentosa na membrana plasmática, de forma a promover a estrutura e motilidade da célula (GEIGER; AYALON, 1992; ODA et al., 2009; PERRIN; ERVASTI, 2010).

Após a incubação do primário, sucederam-se três lavagens de 10 minutos com $1 \mathrm{~mL}$ de PBS e a incubação do anticorpo secundário (1:2.000, v/v) em uma solução de Triton X-100 a 0,05\% (v/v). O anticorpo secundário utilizado para os ensaios consistiu no Alexa Fluor 594 anti-camundongo produzido em jumento. O anticorpo secundário foi incubado sob branda agitação por $2 \mathrm{~h}$, seguido de três lavagens de 5 minutos em $1 \mathrm{~mL}$ de PBS e posterior aplicação do marcador fluorescente DAPI (1:100.000 em PBS, m/v). O DAPI (4',6-diamino-fenilindola) é um marcador fluorescente que tem máxima absorção no comprimento de onda de $358 \mathrm{~nm}$ e máxima emissão em $461 \mathrm{~nm}$ (azul) e se liga fortemente a regiões ricas de adenina-timina do DNA, sendo um marcador nuclear (TROTTA et al., 1993). Quatro lavagens, com $1 \mathrm{~mL}$ de PBS por 10 min foram então realizadas para evitar excesso de marcação pelo DAPI. As lamínulas foram, então, retiradas e postas sobre $18 \mu \mathrm{L}$ de Fluormount ${ }^{\mathrm{TM}} \mathrm{em}$ lâminas limpas. As lâminas foram avaliadas no microscópio de fluorescência da marca Nikon Eclipse 80i.

\subsection{Análise de dados e tratamento estatístico empregados nos resultados obtidos}

Os softwares empregados para o tratamento de dados neste projeto consistiram em: GraphPad Prism 6.0, Microsoft Office Excel 2016, Minitab 17 e OriginPro 9. Os testes estatísticos e tratamento dos dados empregados foram: a análise de variância de duas vias (ANOVA two-way), o teste $t$ de Student, a regressão não-linear e o teste fatorial completo. Os testes que requeriam significância estatística, o fizeram a nível de $5 \%$, isto é, quando $p<0,05$, considerou-se que as amostras apresentavam distinção estatística significativa.

A ANOVA two-way foi utilizada quando uma resposta era averiguada mediante duas variáveis. Para se comparar todas as amostras presentes no ensaio, realizaramse as múltiplas comparações, também denominado teste post-hoc. Utilizou-se, majoritarimante, o teste de Holm-Šídák, que apresenta o valor de $p$ ajustado, embora não calcule intervalos de confiança, os quais não são aqui necessários. O teste $t$ de Student é utilizado para uma comparação singular da média de duas amostras. No 
caso, utiliza-se o teste não-pareado porque as amostras comparadas nem sempre apresentam mesmo tamanho amostral. O teste $t$ de Student é um teste paramétrico, não recomendado para amostras pequenas ou que não apresentem distribuição normal. A aplicação da análise estatística foi apenas utilizada em caso de variáveis que sigam a normalidade, como tamanho, PDI e potencial zeta.

A regressão não-linear foi realizada para obtenção de modelos em relação a pontos experimentais. Caso se deseje utilizar a equação de determinada regressão, deve-se observar o valor do coeficiente de determinação ajustado $\left(R^{2}{ }\right.$ adj $)$, o qual deve ser próximo do valor unitário. Caso este não seja o intuito, observa-se apenas se o ajuste foi sucedido, averiguando o valor de $p$, o qual deve ser inferior a $5 \%$.

Por fim, o teste fatorial completo aborda a seleção de variáveis para a investigação de determinado processo. Tais variáveis são subdivididas em pontos para melhor inspeção, os quais são denominados subníveis. Realizam-se todas as combinações dos subníveis de todas as variáveis em testes experimentais para se obter variáveis-resposta de interesse. Pode-se averiguar, desse modo, os efeitos individuais de cada uma das variáveis e como elas afetam a variável-resposta. No estudo aqui realizado, empregou-se um teste fatorial $2^{2}$, em que duas variáveis são estudadas e cada uma é dividida em dois subníveis (BOX et al., 2005; MONTGOMERY, 2001; MONTGOMERY; RUNGER, 2014). 


\section{RESULTADOS}

\subsection{Caracterização de nanopartículas vazias (NPs) e encapsuladas com FITC (FITC-NPs) e avaliação de seu processo de síntese}

4.1.1 Teste fatorial $2^{2}$ para padronização do processo de confecção de nanopartículas vazias

O teste fatorial em dois níveis foi empregado para avaliar o efeito de duas variáveis: o volume de ressuspensão do pellet de partículas em T-80 (variável A) e o tamanho da barra de agitação empregada neste processo no período de $1 \mathrm{~h}$ (variável B). Este ensaio foi realizado em NPs formuladas com DDAB. As variáveis para a análise fatorial, incluindo seus respectivos subníveis estão detalhadas na Tabela 1.

Tabela 1 - Definição das variáveis e seus subníveis empregados no teste fatorial $2^{2}$ para otimização da aplicação de T-80 às nanopartículas.

\begin{tabular}{|c|c|c|}
\hline & Variável & Subnível \\
\hline A & Volume de ressuspensão em T-80 & $\begin{array}{l}+\quad 2 \mathrm{~mL} \text { de T-80 } \\
-\quad 1 \mathrm{~mL} \text { de T-80 }\end{array}$ \\
\hline B & Tamanho da barra de agitação & $\begin{array}{l}+\quad 10 \times 8 \times 8 \mathrm{~mm} \\
-\quad 8 \times 1,5 \times 1 \mathrm{~mm}\end{array}$ \\
\hline
\end{tabular}

Partindo-se desta definição, o planejamento experimental no teste fatorial envolve a combinação de todos os subníveis das variáveis. A Tabela 2 revela 0 planejamento experimental e os resultados obtidos para cada combinação. A tabela está estruturada em ordem padrão, em que se exibe a montagem experimental a partir dos subníveis inferiores (-). Contudo, os experimentos são realizados em ordem aleatória, de forma a corroborar a independência avaliativa entre os processos. 
Tabela 2 - Planejamento experimental do teste fatorial $2^{2}$ exibido em ordem padrão e os resultados obtidos.

\begin{tabular}{ccccccc}
\hline Ordem & Ordem & Variável & Variável & Interação & Tamanho & Potencial $\zeta$ \\
Padrão & Aleatória & A & B & AB & $(\mathrm{nm})$ & $(\mathrm{mV})$ \\
1 & 3 & - & - & + & 69,92 & $-0,55$ \\
2 & 4 & + & - & - & 66,93 & $-3,59$ \\
3 & 2 & - & + & - & 78,96 & $-1,10$ \\
4 & 1 & + & + & + & 69,35 & $-9,00$ \\
\hline
\end{tabular}

Pode-se obter os efeitos individuais de cada variável e da interação $(A B)$ após a realização dos experimentos. A seguir, na Tabela 3 , expõe-se os efeitos obtidos para cada uma das variáveis e para a interação entre elas:

Tabela 3 - Efeitos obtidos para cada uma das variáveis (A e B) e da interação entre elas (AB) para as respostas de tamanho e potencial zeta das partículas confeccionadas após o teste fatorial $2^{2}$. I consiste na variável com os valores médios de tamanho e de potencial zeta.

\begin{tabular}{ccc}
\hline & Efeito no tamanho $(\mathrm{nm})$ & Efeito no potencial $\zeta(\mathrm{mV})$ \\
$\mathrm{A}$ & $-6,35$ & $-5,466$ \\
$\mathrm{~B}$ & 5,78 & $-2,976$ \\
$\mathrm{AB}$ & $-3,26$ & $-2,429$ \\
$\mathrm{I}$ & 71,26 & $-3,559$ \\
\hline
\end{tabular}

Nas análises deste teste fatorial não foram realizadas replicatas, deve-se então averiguar os efeitos das variáveis e da interação em escala de probabilidade. Caso os efeitos divirjam consideravelmente à reta da normalidade, pode-se pressupor que os efeitos sejam significativos, como ilustra a Figura 6. 
A

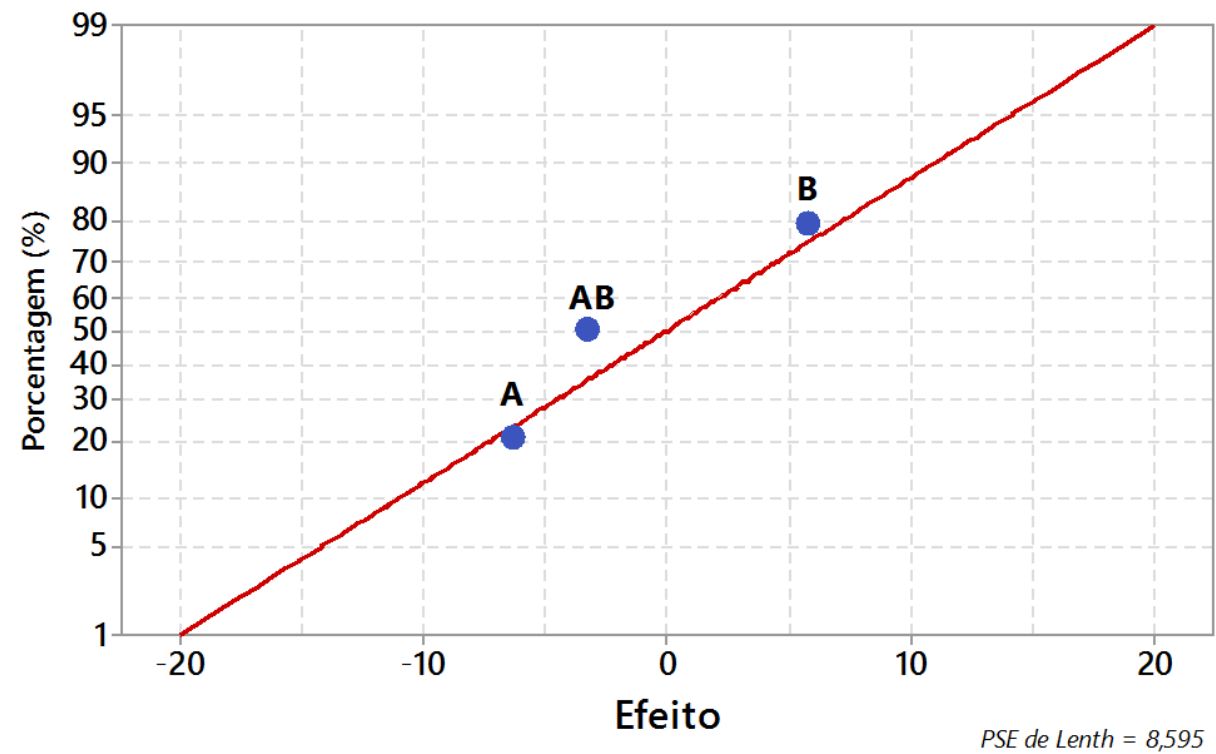

B

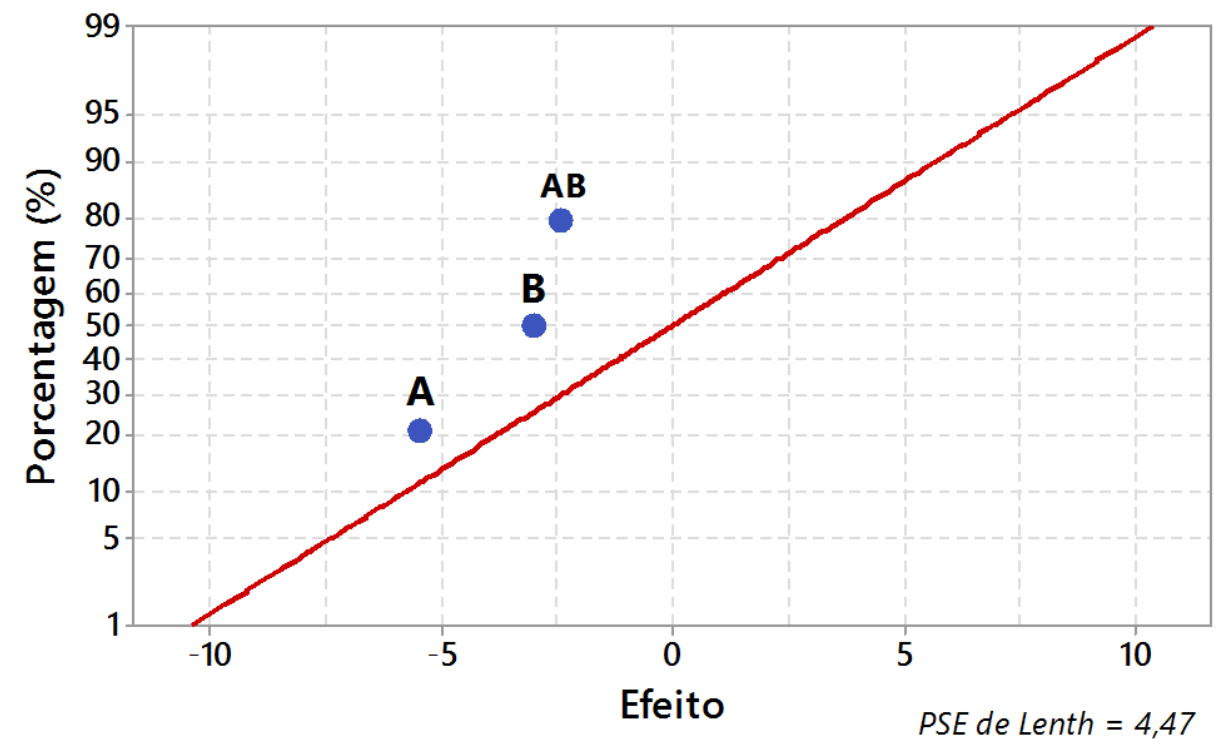

Figura 6 - $A$ análise em escala de probabilidade dos efeitos das variáveis $A$ e $B$; e da interação $A B$ para o tamanho $(A)$ e para o potencial zeta $(B)$.

O método de Cuthbert Daniel considera que a avaliação gráfica dos efeitos em escala de probabilidade permite separar efeitos que seriam significativos daqueles não-significativos, especialmente quando da não-realização de replicatas em ensaios que envolvem combinação de variáveis (DANIEL, 1959). Este método acaba sendo 
possível de ser aplicado para a análise de testes fatoriais não-replicados. Assim, todos os efeitos avaliados, neste caso os 3 efeitos, são plotados de acordo com seu valor, de forma crescente; e a distribuição de seus contrastes entre os pares dos efeitos, elementos utilizados para calcular os efeitos em si; a qual segue uma distribuição aproximadamente normal. Espera-se que determinados efeitos se posicionem na reta denominada "reta-erro", uma vez que estes efeitos podem ser produzidos apenas por variações ocasionais. No entanto, por vezes, determinados efeitos podem se distanciar da reta-erro, devendo ser considerados efeitos significantes, isto é, não frutos do acaso (MONTGOMERY; RUNGER, 2014).

Nota-se que a interação AB é significativa para o tamanho; e todas as variáveis e a interação entre elas para o potencial zeta. Uma síntese dos resultados de significância, com o sinal do efeito, está tabelada abaixo:

Tabela 4 - Resumo da análise estatística realizada a partir dos resultados obtidos no teste do fatorial completo $2^{2}$. As flechas indicam como que a variável/interação afeta o valor da resposta (tamanho ou potenial zeta).

\begin{tabular}{ccc}
\hline & Efeito no tamanho & Efeito no potencial $\zeta$ \\
A & Não significante & Significante $\downarrow$ \\
B & Não significante & Significante $\downarrow$ \\
AB & Significante $\downarrow$ & Significante $\downarrow$ \\
\hline
\end{tabular}

Frente aos resultados adquiridos no teste fatorial realizado, pode-se concluir que o quadro de otimização do processo de adsorção do T-80 estaria representado pela combinação $[A(-), B(+)]$, em que ocorre o emprego da ressuspensão das nanopartículas em $1 \mathrm{~mL}$ de T-80 (4\%) em água destilada $[A(-)]$ e a agitação realizada com barra magnética de maior dimensão $[\mathrm{B}(+)]$. Nesta combinação tem-se o subnível inferior da interação das variáveis $[\mathrm{AB}(-)]$, que contribui para menores tamanhos dos particulados e para potenciais zeta mais negativos. O efeito favorável à carga superficial também é potencializado por $[\mathrm{A}(-)]$, mas não por $[\mathrm{B}(+)]$. Não obstante, 0 efeito resultante desta escolha de parâmetros ainda beneficia mais eficientemente 0 potencial zeta pelos efeitos associados da variável $A$ e da interação $A B$. 
4.1.2 Avaliação dos parâmetros de nanopartículas vazias nas etapas do seu processo de confecção

A descrição do tamanho, PDI e potencial zeta das nanopartículas em todas as etapas do processo mediante a comparação de dois regimes de sonicação, um de cinco pulsos de 30 segundos e outro de cinco pulsos de 50 segundos, revelou os resultados demonstrados na Figura 7. Para este experimento, utilizou-se o DDAB como tensoativo no processo de confecção.

A

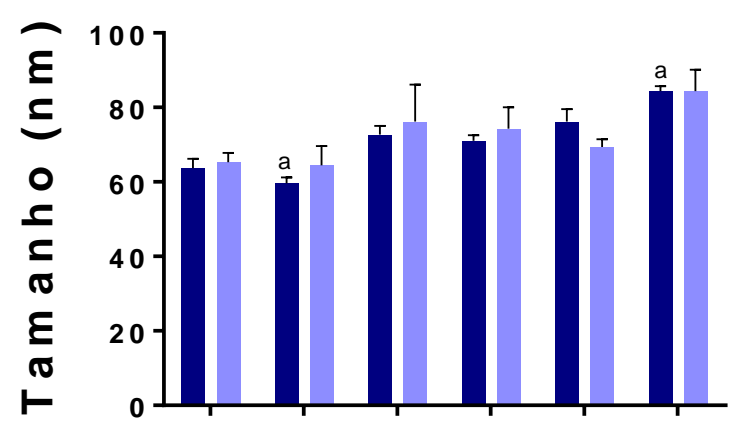

C

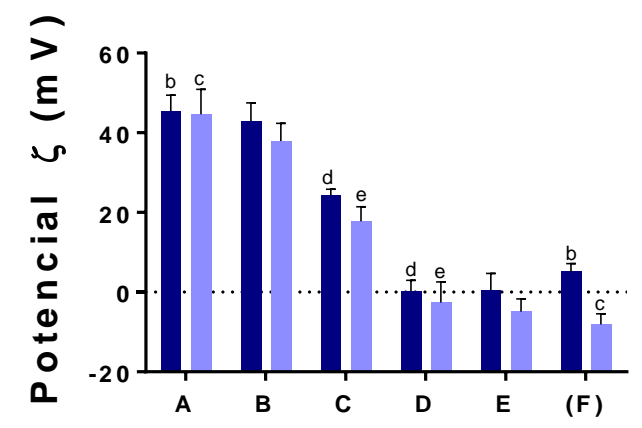

B

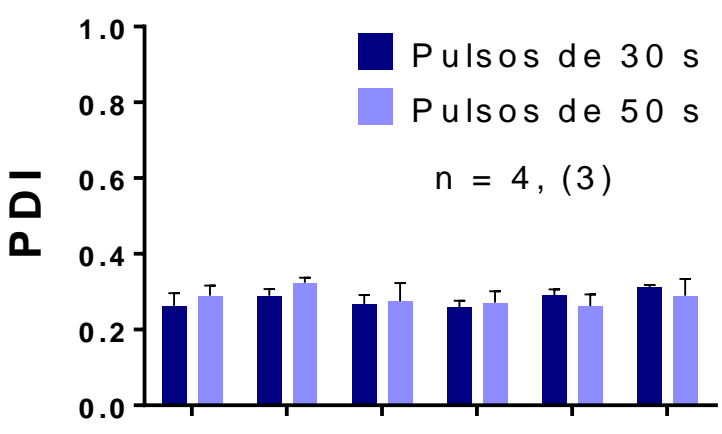

D

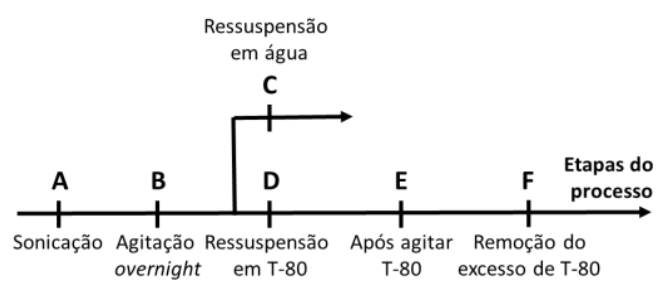

Etapas da síntese de nanopartículas

Figura 7 - Tamanho (A), PDI (B) e potencial zeta (C) obtidos na caracterização do processo de obtenção de nanopartículas vazias para dois regimes de sonicação, um com pulsos de 30 segundos e outro com pulsos de 50 segundos. Linha do tempo das etapas avaliadas na síntese das nanopartículas (D) dentre elas etapa A: Pós-sonicação; B: pós-overnight; C: após ressuspensão em meio aquoso (etapa controle); D: após ressuspensão em T-80; E: após $1 \mathrm{~h}$ em contato com T-80; F: após remoção do excesso de T-80. Valores expressos como média \pm s.e.m. ${ }^{(a-e)} p<0,5$ de acordo com análise de variância two-way com as múltiplas comparações pelo método de Holm-Šídák $(n=3-4)$

O tamanho das partículas não é fortemente afetado pelos distintos tratamentos de sonicação $(F(1,34)=0,16050, p=0,6912)$. Contudo, as operações do processo de confecção de nanopartículas contribuem para um leve aumento no tamanho dos 
particulados $(F(5,34)=5,8101, p=0,0006)$. Este aumento, embora significativo, não se constitui exorbitante - nanopartículas deixam de possuir um tamanho médio de $59,63 \pm 1,60 \mathrm{~nm}$ após serem sonicadas com pulsos de 30 segundos e deixadas para evaporação do solvente overnight e atingem tamanhos médios de 84,36 \pm 1,33 nm ( $\left.\mathrm{p}^{\mathrm{a}}<0,0001\right)$ ao fim do processo. O PDI não apresenta variações significativas tanto em relação às etapas da síntese das partículas $(F(5,34)=0,69290, p=0,6323)$ como ao aspecto diferencial da sonicação $(F(1,34)=0,092230, p=0,7632)$. Os valores do índice de polidispersidade variam em torno de 0,259-0,324.

Por outro lado, o potencial zeta revela valores de potencial mais elevados, em torno de $45 \mathrm{mV}$, antes da ressuspensão no T-80. Existe uma clara variação de potencial quando se compara o início e o fim do processo para ambos os regimes de sonicação avaliados ( $\left.\mathrm{p}^{\mathrm{b}}<0,0001, \mathrm{p}^{\mathrm{c}}<0,0001\right)$. A ressuspensão das nanopartículas em água e em T-80 revela que o tensoativo possui a propriedade de causar relevante inversão do potencial superficial das partículas $\left(p^{d}=0,0055, p^{e}=0,0279\right)$. No âmbito geral, o processo de confecção das nanopartículas tem forte influência no potencial zeta, tanto considerando-se as etapas individuais $(F(5,34)=58,282, p<0,0001)$, como a realização de regimes diferenciais de sonicação $(F(1,34)=5,6301, p=$ $0,0235)$.

Desta forma, frente aos resultados expostos quanto ao regime de sonicação, estabeleceu-se que 5 pulsos de 50 segundos de sonicação espaçados por 30 segundos sem sonicação em banho de gelo conferiram melhores características, quanto ao tamanho e ao potencial zeta, às nanopartículas confeccionadas. Esta conclusão é especialmente evidenciada quando o perfil do potencial zeta é analisado ao longo da síntese dos particulados.

\subsubsection{Comparação entre o emprego dos tensoativos DDAB e DMAB na síntese de NPS}

A análise comparativa quanto ao uso de DDAB ou DMAB para a confecção de nanopartículas de PLGA foi verificado também realizando-se mensurações em cada uma das etapas de síntese das partículas. Este teste foi realizado com a sonicação em pulsos de 50 segundos, padronizado em teste anterior. A Figura 8 exibe os resultados obtidos de tal comparação. 
A

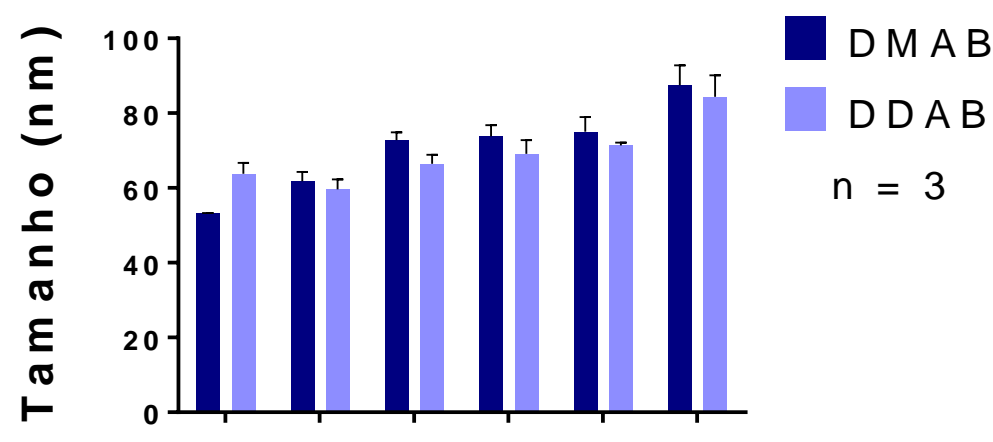

B

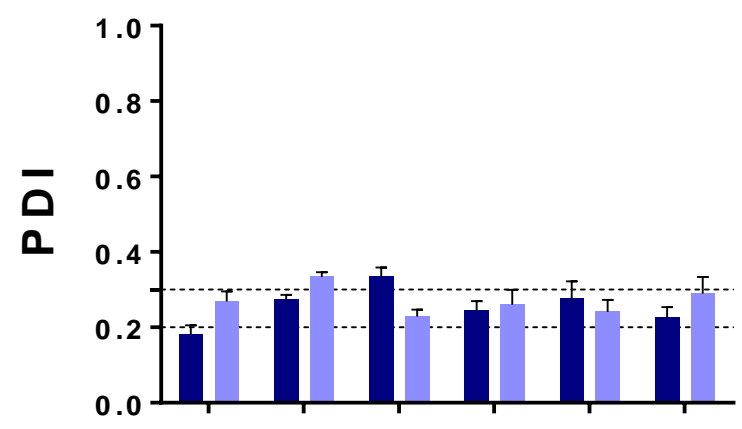

C

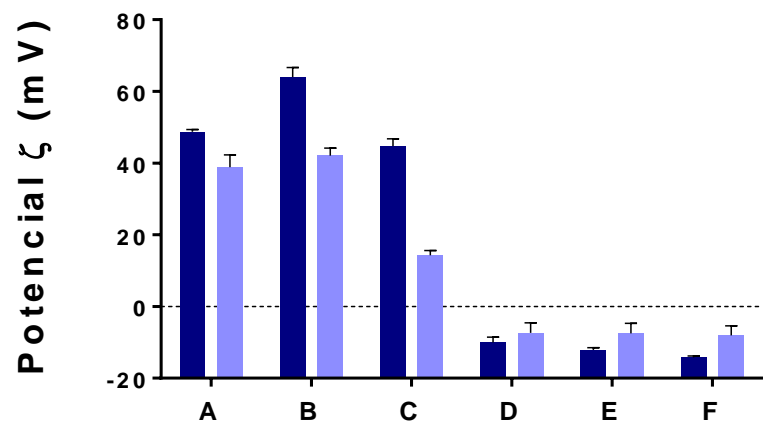

Etapas da síntese de nanopartículas

Figura 8 - Tamanho (A), PDI (B) e potencial zeta (C) obtidos na caracterização do processo de síntese de nanopartículas vazias para o uso de DMAB (índigo) e DDAB (ciano). Etapa A: Pós-sonicação; B: pós-overnight; C: após ressuspensão em meio aquoso; D: após ressuspensão em T-80; E: após $1 \mathrm{~h}$ em contato com T-80; F: após remoção do excesso de T-80, confome exibido em Figura 7D. Valores expressos como média \pm s.e.m. Não houve diferenças estatisticamente significativas de acordo com análise de variância two-way com as múltiplas comparações pelo método de Holm-Šídák.

Nenhuma comparação realizada entre os tensoativos evidenciou significância estatística ao nível de $5 \%$ em tal experimento. Contudo, pode-se averiguar que nanopartículas confeccionadas utilizando-se o DMAB tendem a apresentar um menor 
PDI e um potencial zeta mais negativo no fim do processo. Logo, padronizou-se que uma solução de DMAB a $1 \%(\mathrm{~m} / \mathrm{m})$ em água destilada seria utilizada para efetuar o processo de emulsificação óleo/água para a confecção das nanopartículas, uma vez que se observou esta tendência de as partículas confeccionadas a partir deste processo serem menos polidispersas e possuírem um potencial zeta mais negativo na etapa final da síntese.

\subsubsection{Características de nanopartículas obtidas pelo processo selecionado}

Padronizou-se o processo para confecção de nanopartículas poliméricas de PLGA realizando o emprego de uma solução de DMAB a $1 \%(\mathrm{~m} / \mathrm{m})$ em água para a emulsifcação, efetuando-se a sonicação com 5 pulsos de 50 segundos espaçados por 30 segundos sem sonicação e utilizando $1 \mathrm{~mL}$ de uma solução de T-80 (4\%) em água em agitação com uma pequena barra magnética.

A Tabela 5 revela a comparação da distribuição de tamanho, potencial zeta e fotomicrografias realizadas por MEV-FEG de NP(-T80), isto é, nanopartículas sem T80 adsorvido e NP(+T80), no caso das com T-80 adsorvido; para a caracterização dos carreadores sintetizados. 
Tabela 5 - Comparação de NPs com T-80 adsorvido e sem este tensoativo de acordo com o imageamento em MEV-FEG, distribuição de tamanho e de potencial zeta. As barras de tamanho se referem a $1 \mu \mathrm{m}$.

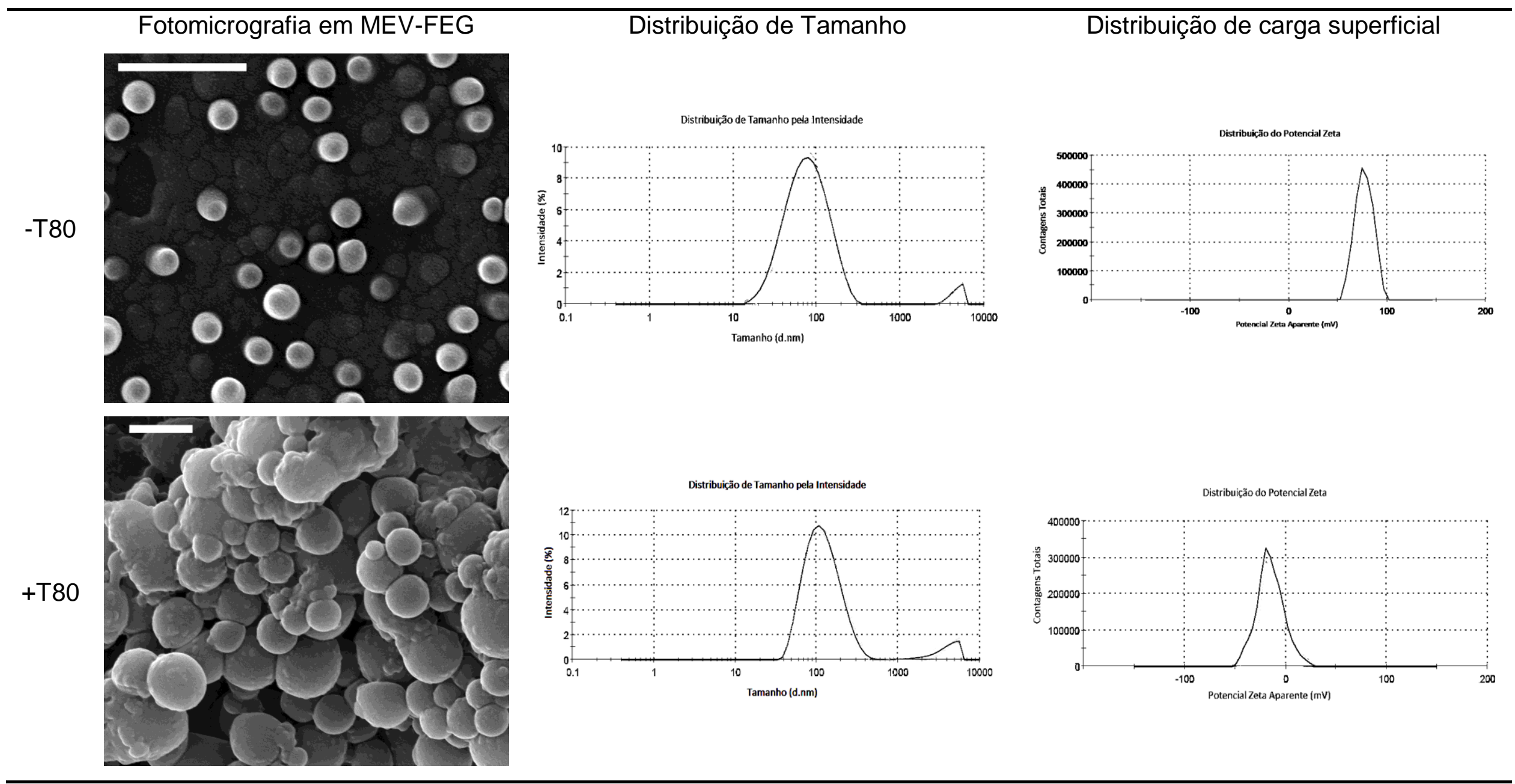


4.1.5 Caracterização de nanopartículas conjugadas à fluorescina isotiocianato isômero I (FITC-NPS)

Nanopartículas encapsuladas com FITC foram confeccionadas e caracterizadas em três processos independentes $(n=3)$. As partículas apresentaram uma distribuição monodispersa, como pode ser verificado nos perfis de distribuição de uma das replicatas na Figura 9.

A

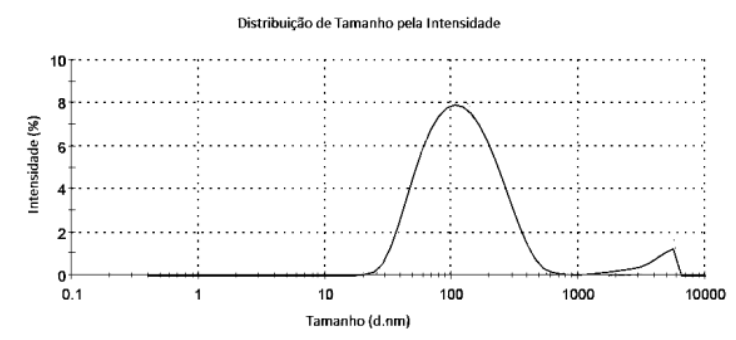

B

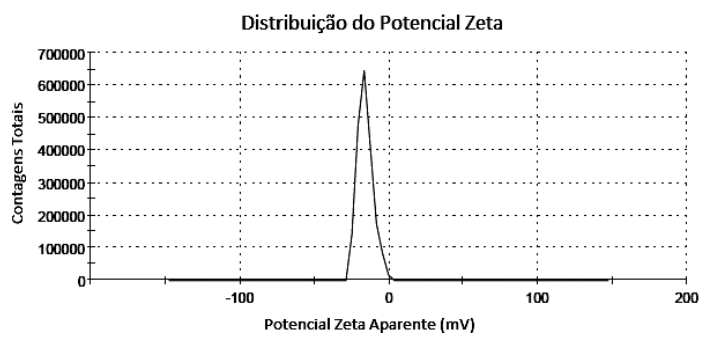

Figura 9 - Distribuição das medidas de tamanho (A) e do potencial zeta (B) aparente de uma das replicatas de FITC-NPS.

A Figura 10 compara as propriedades de FITC-NPs e NPs vazias. Nanopartículas encapsuladas com FITC possuem tamanho médio de 118,50 \pm 9,14 $\mathrm{nm}$, e PDI de 0,294 $\pm 0,041$. O tamanho das FITC-NPs é significantemente maior que o de NPs vazias, as quais possuem $87,47 \pm 5,29 \mathrm{~nm}(\mathrm{p}=0,0424)$, mas seu PDI não difere nesta comparação. NPs possuem um PDI médio de 0,226 $\pm 0,028(p=0,2407)$. No que tange o potencial zeta, FITC-NPs, com -17,98 $\pm 1,41 \mathrm{mV}$, apresentam uma forte tendência em possuírem potenciais mais negativos que NPs vazias, as quais possuíram os potenciais superficias de $-14,23 \pm 0,43 \mathrm{mV}(p=0,0635)$. 
A

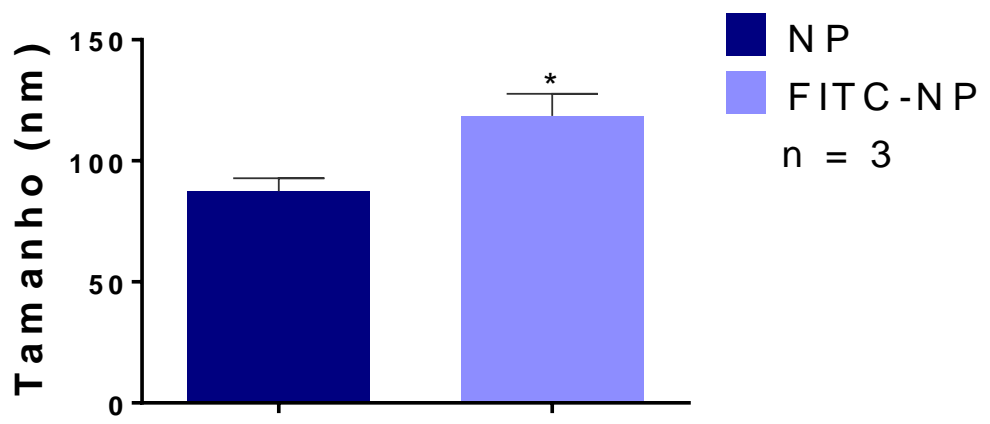

B
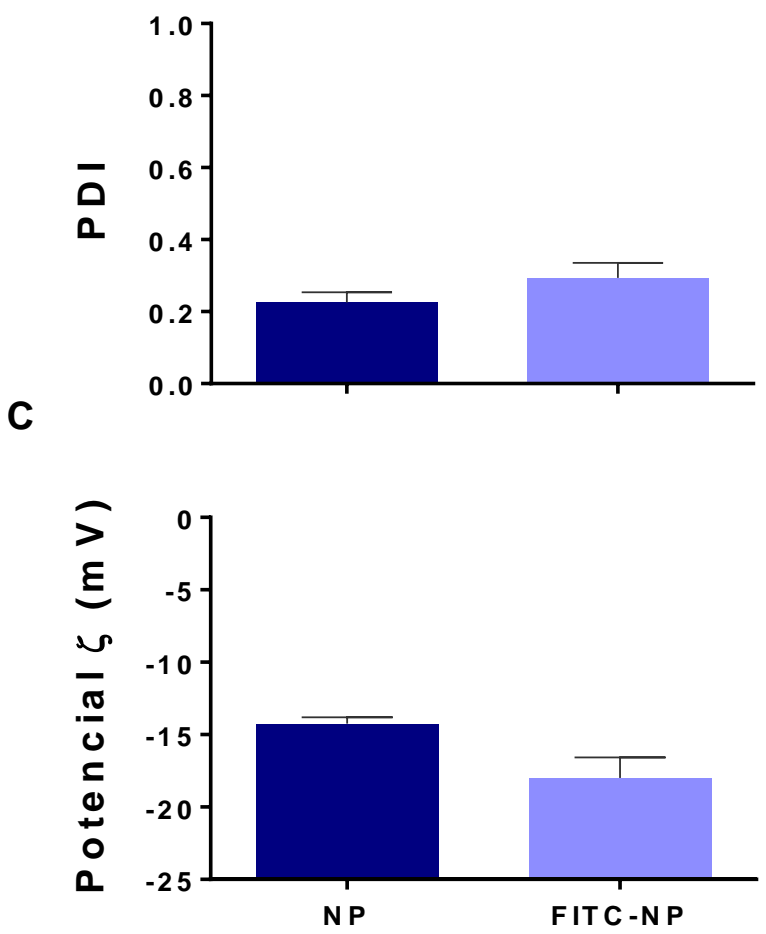

Figura 10 - Comparação das propriedades de NPs vazias e FITC-NPs quanto a tamanho (A), PDI (B), e potencial zeta (C). Valores expressos como média \pm s.e.m. ${ }^{*} p<0,05$ vs. NP, de acordo com o teste $t$ de Student bicaudal para dados não-pareados $(n=3)$. 


\subsection{Caracterização de lipossomos constituidos por DPPC e DOPC e otimização de seu processo de síntese}

\subsubsection{Avaliação da cinética de formação de lipossomos vazios de DPPC e DOPC}

Investigou-se a cinética de formação de lipossomos consituídos por DPPC ou DOPC. A Figura 11 exibe os resultados obtidos para cada tipo de lipossomo em termos do tamanho e PDI das vesículas formadas.

A

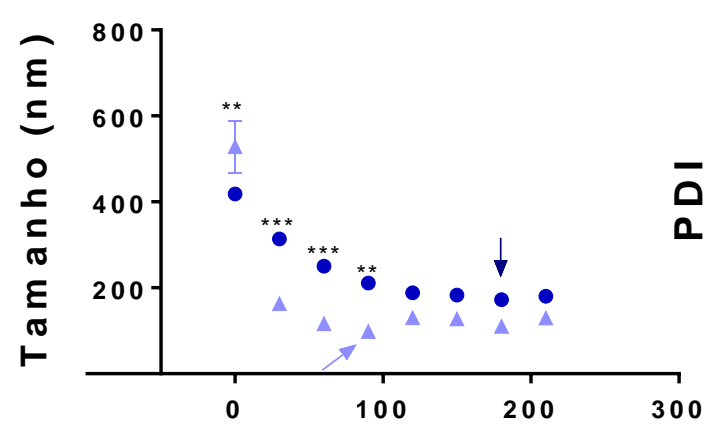

B

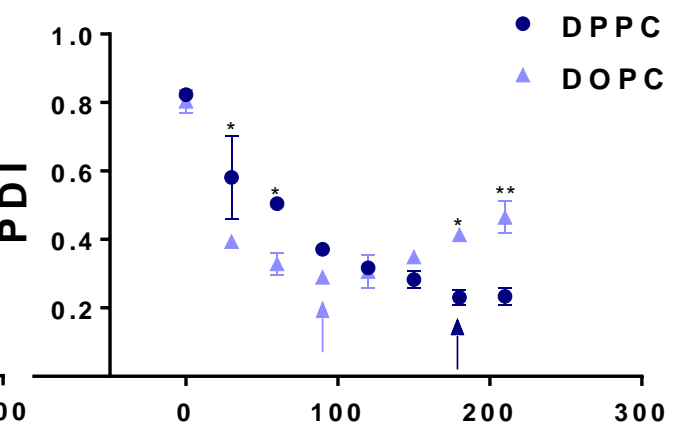

Tempode sonicação (pulsos de $30 \mathrm{~s}$ )

Figura 11 - Curvas de formação de lipossomos formados com DPPC ou DOPC, com medições de tamanho (A) e PDI (B). Valores expressos como média \pm s.e.m. ${ }^{*} p<0,05 ;{ }^{* *} p<0,01 ;{ }^{* * *} p<0,001 v s$. a fosfatidilcolina, de acordo com a ANOVA de duas vias com o ajuste para múltiplas comparações pelo teste de Holm-Šídák $(n=2)$. As flechas indicam quando os menores tamanhos e PDI para cada grupo foram obtidos.

As diferentes fosfatidilcolinas empregadas claramente alteram o padrão de formação de lipossomos. No caso de lipossomos formados de DPPC, verifica-se o padrão assintótico das curvas tanto para o tamanho, quanto para o PDI em função do tempo de sonicação. Estabeleceu-se, assim, como tempo ótimo de sonicação para o sonicador de haste utilizado como sendo de 6 pulsos de 30 segundos. No caso de lipossomos formados por DOPC, o padrão assintótico é verificado apenas para a curva de tamanho em função do tempo de sonicação. Na curva de PDI, um ponto de mínimo se estabelece claramente após 3 pulsos de 30 segundos, ponto que também consiste no estabelecimento da assíntota na curva de tamanho.

A avaliação estatística indica que, para o tamanho, houve uma diferença significativa entre os tipos de fosfatidilcolina empregadas $(F(1,16)=54,585, \quad p<$ 
0,0001), entre o tempo de sonicação utilizado $(F(7,16)=82,340, p<0,0001)$ e, inclusive, uma interação entre as duas variáveis $(F(7,16)=10,738, p<0,0001)$. Indicações pontuais mostram que nos pontos antes de qualquer sonicação ( $p=$ $0,0019)$, em $30 \mathrm{~s}(\mathrm{p}=0,0001)$, em $60 \mathrm{~s}(\mathrm{p}=0,0004)$ e em $90 \mathrm{~s}(\mathrm{p}=0,0018)$ as médias de tamanho dos lipossomos com diferentes fosfatidilcolinas diferem significantemente. Ressalta-se que pontos posteriores não evidenciaram diferenças significativas, mas as probabilidades verificadas foram próximas ao nível de significância de 5\% (0,0888 $\leq p \leq 0,0896)$. Quanto ao PDI, não se verificaram efeitos diferenciais gerais para emprego de diferentes fosfatidilcolinas $(F(1,16)=0,0012714, p=0,9720)$, mas sim pelo tempo de sonicação $(F(7,16)=39,309, p<0,0001)$. Existe, também neste caso, um efeito da interação entre a fosfatidilcolina empregada e o tempo de sonicação $(F(7$, 16) $=7,9259, p=0,0003)$. Mediante a verificação em cada pulso de sonicação, o PDI das populações de lipossomos se distingue após $30 s(p=0,0234), 60 s(p=0,0261)$, $180 s(p=0,0234)$ e $210 s(p=0,0049)$.

\subsubsection{Avaliação dos parâmetros de lipossomos vazios em etapas de síntese}

A caracterização consecutiva se faz quanto aos lipossomos em possíveis etapas de seu processo de confecção. Tal procedimento foi feita em lipossomos de DPPC. Realizou-se, neste caso, a medição de tamanho, de PDI e de potencial zeta, nos lipossomos após processo sequenciais de sonicação, filtração, e coleta de sobrenadante residual a uma centrifugação; averiguando-se, concomitantemente, dois diferentes métodos para evaporação do clorofórmio. A Figura 12 exibe os resultados obtidos neste ensaio. 
A

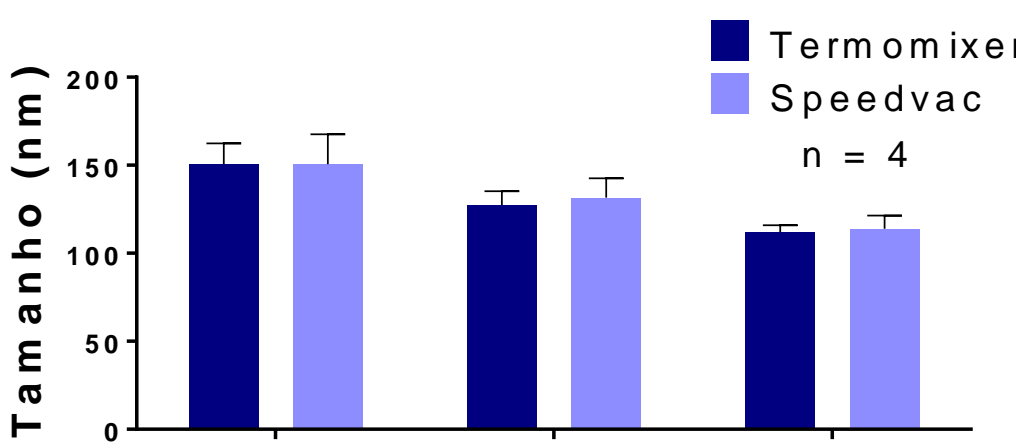

B

C
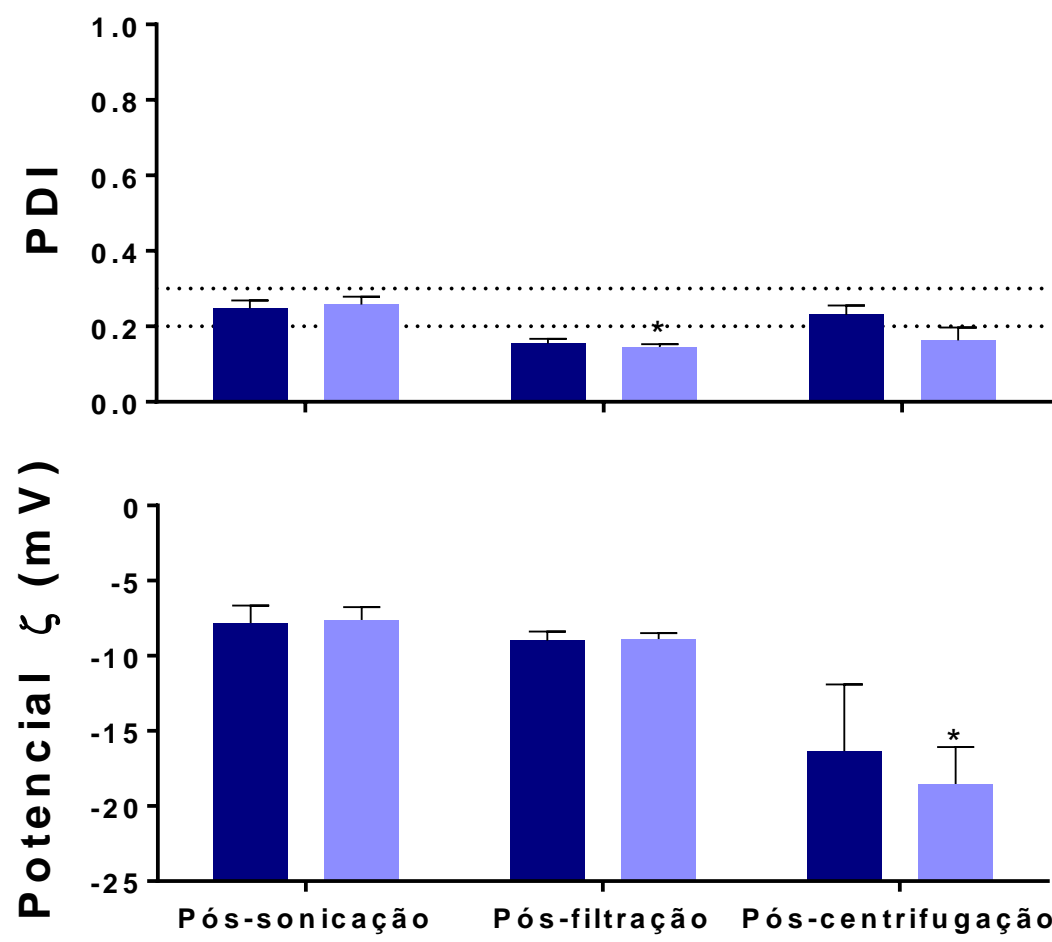

Etapas da síntese de lipossomos

Figura 12 - Avaliação do tamanho (A), PDI (B) e potencial zeta (C) de lipossomos formados com DPPC. Valores expressos como média \pm s.e.m. * $p<0,05$ vs. grupo de pós-sonicação, conforme a análise de variância em duas vias com as múltiplas comparações realizadas pelo teste de Holm-Šíák $(n=4)$.

Os diferentes métodos de evaporação empregados, isto é, a evaporação sob agitação branda a $37^{\circ} \mathrm{C}$ por $2 \mathrm{~h}$; e a evaporação a vácuo a $37^{\circ} \mathrm{C}$ por $1 \mathrm{~h}$; não demonstraram influência quer no tamanho $(F(1,18)=0,055143, p=0,8170)$, quer no PDI $(F(1,18)=1,5617, p=0,2274)$, ou no potencial zeta $(F(1,18)=0,12671, p=$ 0,7260) dos lipossomos confeccionados. As etapas de confecção, por outro lado, revelam influenciar estes parâmetros, sejam eles o tamanho $(F(2,18)=6,2887, p=$ 0,0085), o índice de polidispersidade $(F(2,18)=11,298, p=0,0007)$ ou o potencial 
zeta $(F(2,18)=11,841, p=0,0005)$. Diferenças entre os grupos são singulares e podem ser verificadas no PDI de amostras tratadas por evaporação a vácuo após serem sonicadas e filtradas ( $p=0,0269)$; assim como no potencial zeta de amostradas submetidas ao mesmo tratamento após serem sonicadas e centrifugadas $(p=0,0340)$.

Frente aos resultados indicados, qualquer uma das técnicas para formação do filme lipídico poderia ser utilizada sem que o resultado acerca das propriedades das vesículas fosse significativamente afetado. Optou-se por utilizar a evaporação do solvente por agitação à temperatura de $37^{\circ} \mathrm{C}$, por $2 \mathrm{~h}$, por ser um método de mais fácil acesso. Ademais, quanto às etapas de processamento das vesículas, decidiu-se por realizar apenas a sonicação e não a filtração ou a centrifugação vigorosa no sistema. Embora a filtração seja uma etapa que contribua para reduzir a polidispersidade dos lipossomos, supõe-se que ela também poderia estar associada a perdas no processo, especialmente quanto à eficiência de encapsulamento. $A$ centrifugação vigorosa, por outro lado, poderia estar comprometendo a integridade das vesículas.

4.2.3 Avaliação do procedimento de centrifugação branda em lipossomos feitos com DOPC (DOPC-LPS) e DPPC (DPPC-LPS)

Outro experimento constituiu o estudo de características de lipossomos de DPPC e DOPC antes e após um procedimento de centrifugação branda para remoção de dióxido de titânio proveniente da etapa de sonicação. A Figura 13 exibe os resultados obtidos neste ensaio. 
A

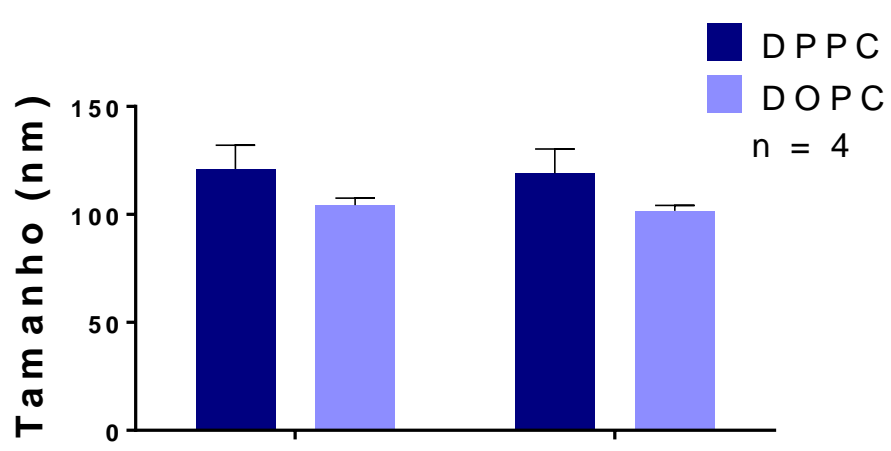

B

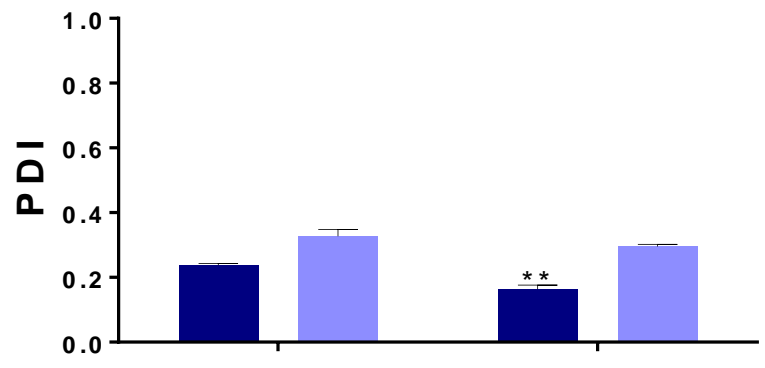

C

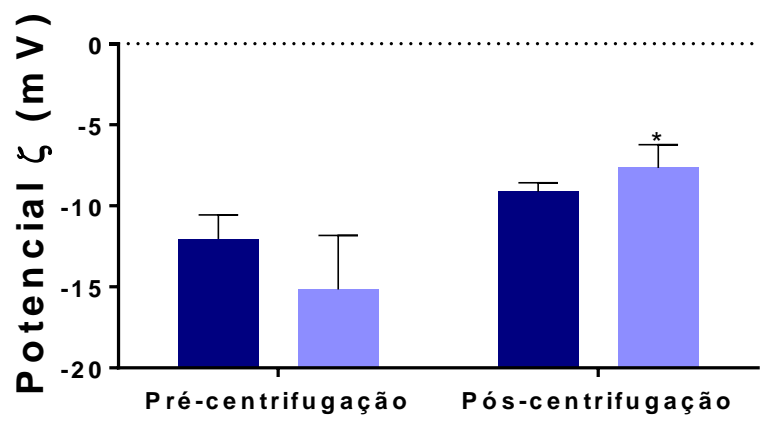

Etapas da síntese de lipossomos

Figura 13 - Caracterização de tamanho (A), PDI (B) e potencial zeta (C) de lipossomos formados com DPPC (índigo) e DOPC (ciano) antes e após uma centrifugação branda. Valores expressos como média \pm s.e.m. ${ }^{*} p<0,05,{ }^{* *} p<0,01$ vs. mesmo grupo antes do tratamento, de acordo com a ANOVA em duas vias com o ajuste para múltiplas comparações pelo teste de Šídák $(n=4)$

A centrifugação não alterou significantemente o tamanho quer de lipossomos com DPPC ( $p=0,9823)$ ou de DOPC ( $p=0,9672)$. Não obstante, existe uma tendência para a redução do PDI, embora este dado só tenha sido evidente para lipossomos com DPPC ( $p=0,0029)$ e não com DOPC ( $p=0,1905)$. Quanto ao potencial zeta, notou-se uma tendência para a diminuição do seu valor em módulo, embora este dado tenha sido estatisticamente significativo para lipossomos de DOPC $(p=0,0396)$ e não nos de DPPC ( $p=0,5315)$. Não obstante, determinou-se o uso preferencial de 
lipossomos com DOPC, devido ao seu tamanho consideravelmente inferior que os com DPPC, portanto DOPC-LPs foram empregados nos ensaios subsequentes.

4.2.4 Caracterização de lipossomos conjugados à fluorescina isotiocianato isômero I (FITC-LPS)

Lipossomos em que a FITC foi encapsulada foram caracterizados em cinco ensaios independentes $(n=5)$. FITC-LPs apresentaram uma distribuição monodispersa, como revela a Figura 14.

A

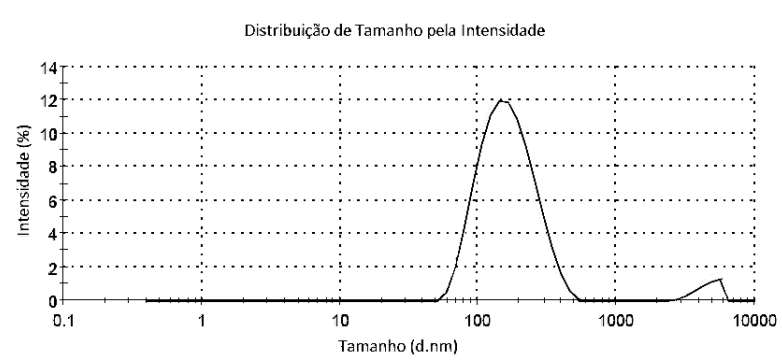

B

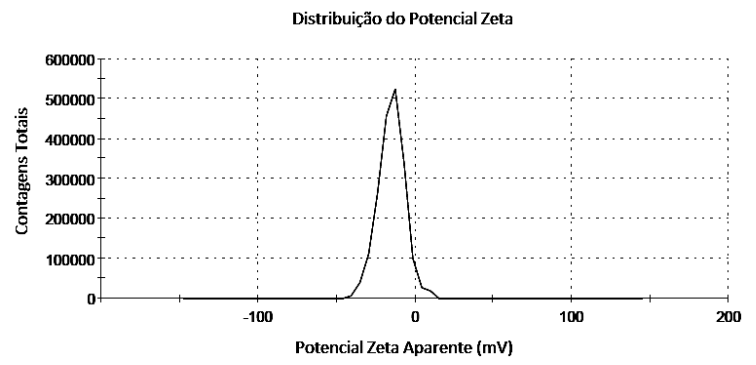

Figura 14 - Distribuição das medidas de tamanho (A) e do potencial zeta (B) aparente de uma das replicatas de FITC-LPS.

Conforme exibe a Figura 15, FITC-LPs apresentaram tamanho médio de $128,00 \pm 8,55 \mathrm{~nm}$, e PDI de 0,257 $\pm 0,018$. Nenhum destes parâmetros revelou ser estatisticamente diferente dos verificados para lipossomos vazios, cujo tamanho médio foi de $126,30 \pm 11,59 \mathrm{~nm}(\mathrm{p}=0,9100)$ e PDI de 0,273 $\pm 0,023(p=0,6123)$. No que tange o potencial zeta, FITC-LPs apresentaram valores médios de -16,21 $\pm 2,81$ $\mathrm{mV}$, ao passo que LPs vazios evidenciaram um valor maior, $-12,33 \pm 1,37 \mathrm{mV}$, mas não significantemente diferente $(p=0,2501)$. 
A

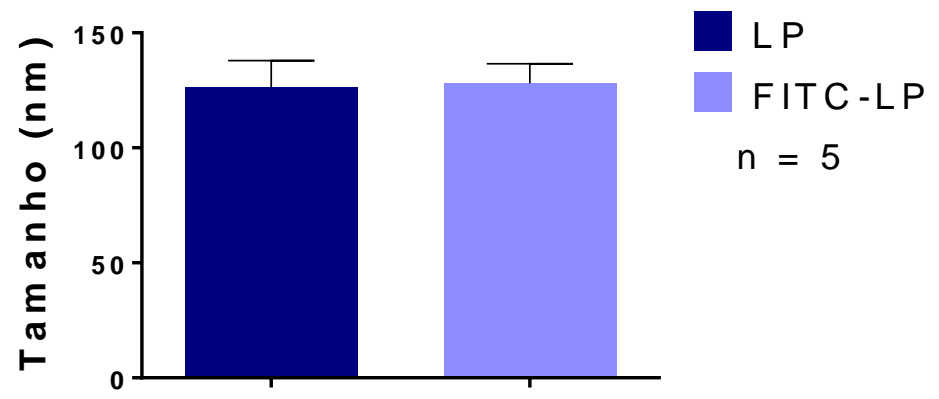

B

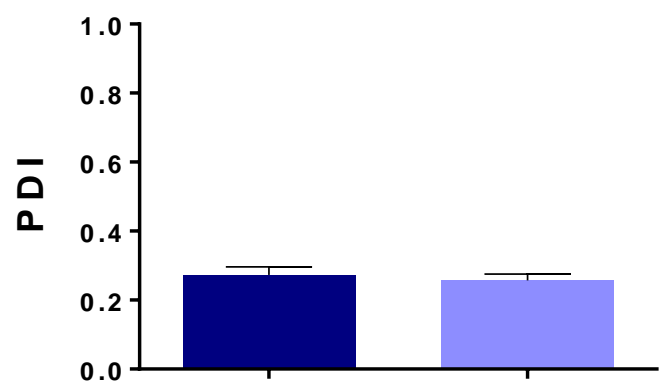

C

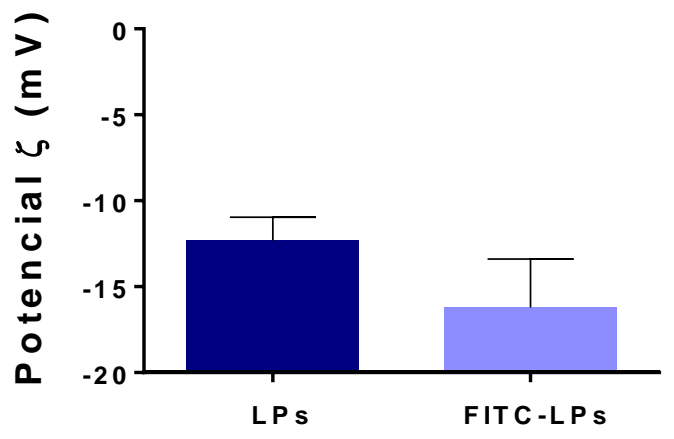

Tipos de lipossom os

Figura 15 - Comparação do tamanho (A), PDI (B) e potencial zeta (C) de LPs vazios e FITC-LPs. Valores expressos como média \pm s.e.m. Não foi observada diferença estatiscamente significativa de acordo com o teste $t$ bicaudal não-pareado $(n=5)$.

4.3 Avaliação da citotoxicidade das formulações de nanopartículas e de lipossomos vazios em cultura de células SH-SY5Y

Os ensaios de citotoxicidade foram realizados para averiguar a viabilidade de neurônios após a aplicação de imunolipossomos ou nanopartículas poliméricas funcionalizados com o polissorbato-80 em cultura celular. Uma diluição seriada foi realizada, e os dados foram plotados em função da concentração em $[\mathrm{mg} / \mathrm{mL}]$. A densidade das formulações foi mensurada, sendo que mediu-se $1,012 \mathrm{~g} / \mathrm{mL}$ para a de 
nanopartículas e 0,998 $\mathrm{g} / \mathrm{mL}$ para a de lipossomos. Em primeiro plano, padronizou-se o método de viabilidade do MTT a ser empregado.

4.3.1 Padronização do teste de viabilidade celular com a aplicação de MTT em células SH-SY5Y e Neuro-2a

A padronização do ensaio de viabilidade utilizando o MTT foi realizada para se investigar qual a faixa de tempo em que a aplicação do composto era necessária para que não houvesse saturação na leitura espectrofotométrica. $O$ experimento descrito na sessão 3.3 foi realizado e os resultados obtidos estão sintetizados na Figura 16.

A

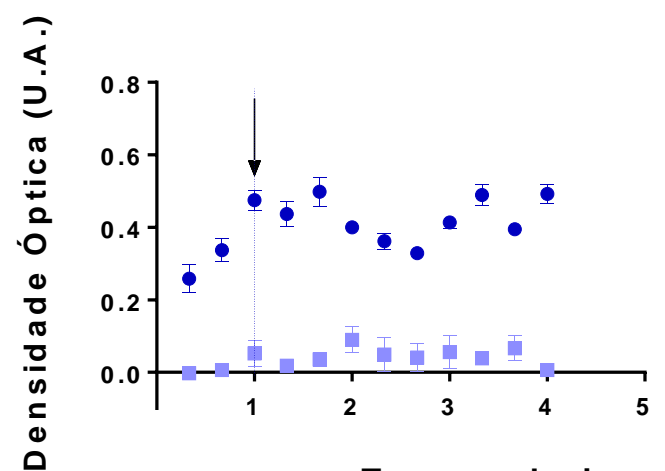

B

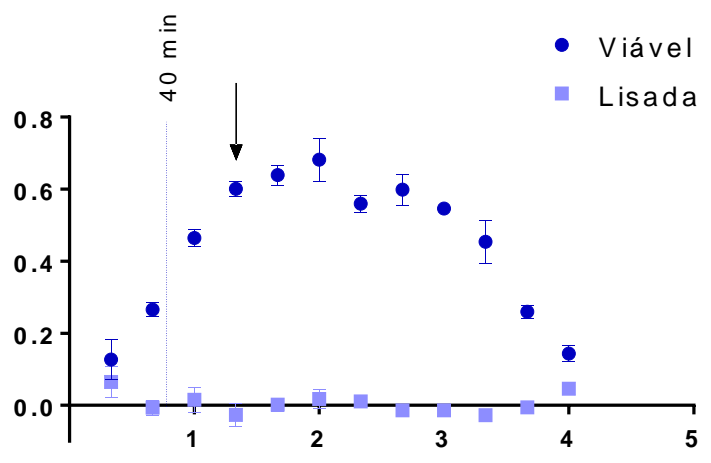

Tempo de incubação do MTT (h)

Figura 16 - Densidade óptica referente à viabilidade de células SH-SY5Y (A) e Neuro-2a (B) em função do tempo de aplicação do MTT em horas (h) para células viávies (índigo) e lisadas (ciano). Valores expressos como média \pm s.e.m. $(n=3-4)$. A seta ilustra quando a reação com o MTT foi considerada finalizada e a linha pontilhada indica o tempo de incubação do MTT nos ensaios de viabilidade.

Deve-se notar que o controle positivo da aplicação do MTT em células lisadas demonstrou que o ensaio desempenhava a formação dos cristais de formazana apenas em poços não tratados com a solução de Triton X-100, ou seja, em células viáveis houve a formação dos cristais, caracterizando a funcionalidade do ensaio.

Quanto ao formato da curva de densidade óptica em função do tempo de células viáveis, verificam-se padrões distintos. Para células SH-SY5Y, observa-se um padrão linear ascendente até o tempo de $1 \mathrm{~h}$ e outro constante após. Já para células $\mathrm{N} 2 \mathrm{a}$, o padrão linear é verificado até $1 \mathrm{~h} 20$ min, ocorre então um breve patamar até 
$3 \mathrm{~h}$ de incubação e posterior diminuição dos valores de densidade óptica até as $4 \mathrm{~h}$ verificadas.

Ao passo que no caso das células SH-SY5Y escolheu-se o tempo de incubação do MTT igual ao de máxima densidade óptica verificada para este grupo, o mesmo não foi realizado com as células N2a. Este fato é justificado que em 40 min de reação já se observava considerável formação da formaza nesta linhagem e a interrupção do processo neste tempo distanciava da possível ocorrência de redução da densidade óptica, como observada na terceira fase do gráfico.

4.3.2 Ensaios de citotoxicidade com a formulação de nanopartículas e imunolipossomos vazios

O ensaio de citotoxicidade dos nanocarreadores foi realizado incubando a formulação por 15 h e $24 \mathrm{~h}$ em cultura de células N2a e com diferentes concentrações da formulação. Um controle positivo do ensaio foi realizado com Triton X-100 no mesmo procedimento de diluição, o qual foi aplicado por $24 \mathrm{~h}$. Para cada um dos resultados obtidos, inclusive para o do Triton, ajustaram-se os dados em curvas farmacológicas de concentração-resposta pelo modelo com inclinação de Hill dada pelo parâmetro "p". A Figura 17 permite visualizar o efeito das formulações em cada um dos regimes de sua aplicação.

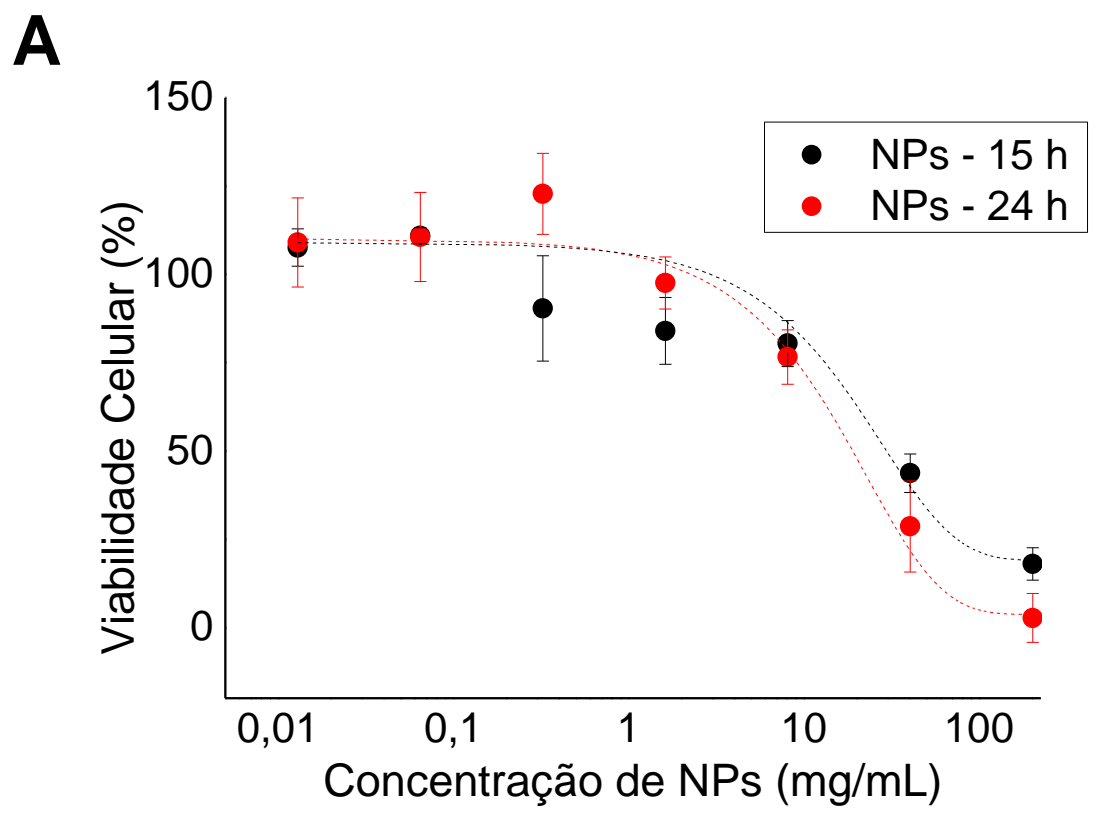

Figura 17 (ver continuação) 
B

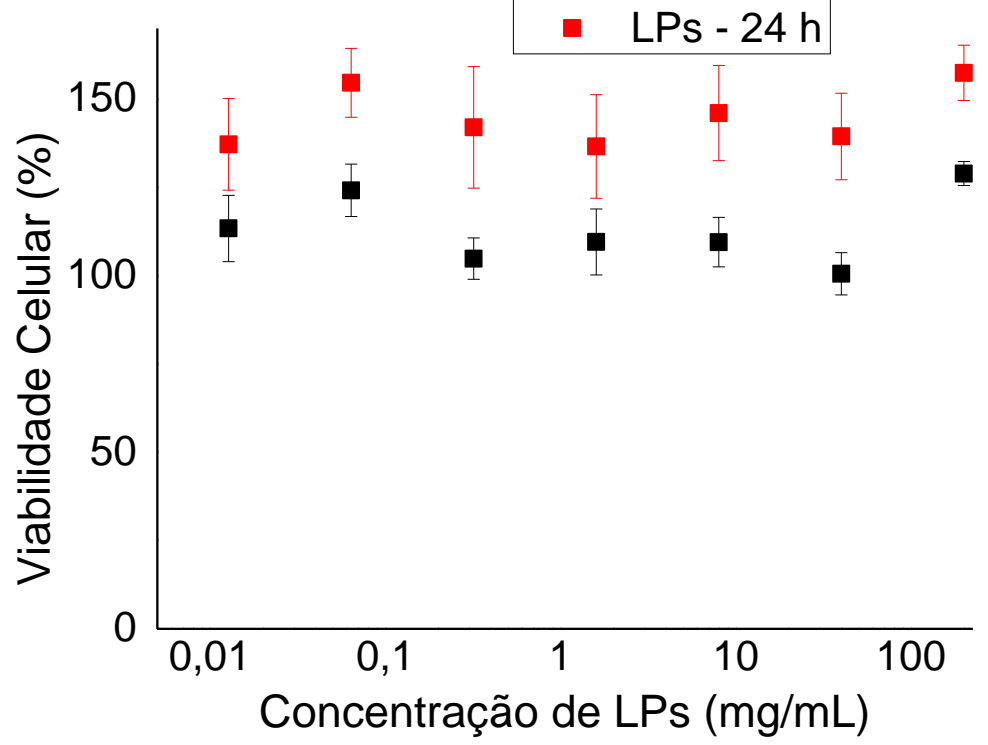

C

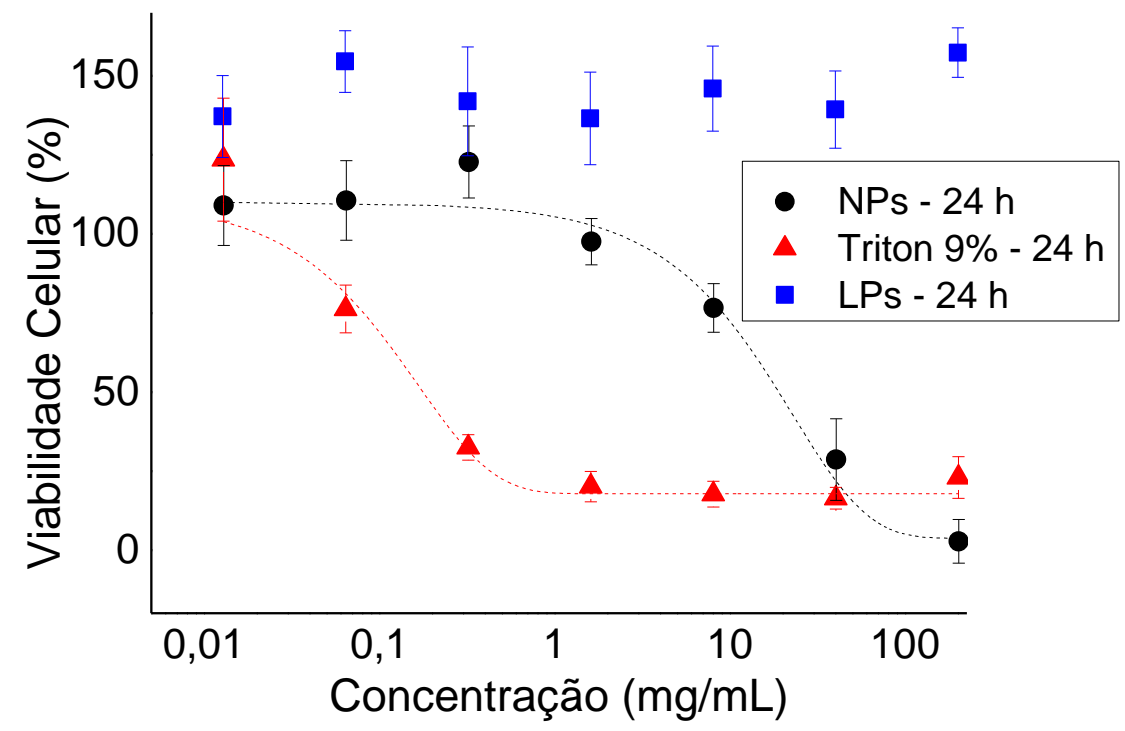

Figura 17 - Resultados dos ensaios de citotoxicidade para nanopartículas $(A, \bullet)$ e lipossomos (B, $\mathbf{\square})$, bem como a comparação com o controle positivo (C), em N2a e ajustes para as curvas farmacológicas. Para os gráficos a e b. "-" se refere à aplicação de 15 h e "-" de 24 h dos nanocarreadores. Valores expressos como média \pm s.e.m. ${ }^{* * *} p<0,001 ;{ }^{* * * *} p<0,0001 \mathrm{vs}$. a concentração de $202,4 \mathrm{mg} / \mathrm{mL}$, de acordo com a análise de variância em duas vias com as múltiplas comparações realizadas pelo teste de Holm-Šíák ( $\mathrm{n}=6$, três experimentos independentes).

Deve-se notar os valores de viabilidade acima de $100 \%$. No caso do ensaio do MTT, o pH elevado do meio de cultura, a exposição dos reagentes à luz ou a presença de compostos redutores, como glutationa reduzida; podem acelerar o processo de 
redução dos sais de tetrazólio, resultando em valores de leitura acima do esperado (RISS et al., 2004).

A Tabela 6 sintetiza os dados dos modelos quanto à $\mathrm{IC}_{50}$ verificada para a formulação em suas aplicações e eficácia de ajuste das curvas farmacológicas, naquelas em que foi possível fazer esse ajuste.

Tabela 6 - Parâmetros para interpretação dos modelos farmacológicos acerca da citotoxicidade das formulações testadas e para validação dos mesmos.

\begin{tabular}{cccc}
\hline Modelo & $\mathrm{IC}_{50}(\mathrm{mg} / \mathrm{mL})$ & $\mathrm{R}^{2}$ adj & $\mathrm{P}$ \\
$\mathrm{NPs}-15 \mathrm{~h}$ & 19,46 & 0,9613 & 0,0003 \\
NPs $-24 \mathrm{~h}$ & 15,82 & 0,9698 & 0,0008 \\
Triton 24 h & 0,129 & 0,9416 & 0,0022 \\
\hline
\end{tabular}

Os modelos foram bem ajustados em todos os ensaios realizados $\left(R^{2}\right.$ adj $\left.\geq 0,95\right)$ e verificou-se significância estatística em tal procedimento ao nível de 5\% ( $p \leq 0,0047)$. O Triton X-100 a 9\% em PBS (v/v), como controle positivo, apresentou a menor $\mathrm{IC}_{50}$, sendo esta quase 122 vezes menor que a IC $50,24 \mathrm{~h}$, isto é, a IC $\mathrm{C}_{50}$ da formulação de nanopartículas quando aplicada por $24 \mathrm{~h}$ na cultura de células.

No caso das nanopartículas, pela aplicação da ANOVA two-way como teste estatístico, pode-se verificar que o tempo não influi consideravelmente na viabilidade celular $(F(3,140)=1,5780, p=0,1974)$, mas que as diferentes concentrações da formulação claramente a afetam $(F(6,140)=53,976, p<0,0001)$. Um patamar de nãocitotoxicidade foi atingido para concentrações menores ou iguais a $324 \mu \mathrm{g} / \mathrm{mL}$, especialmente para aquelas do regime de $24 \mathrm{~h}$, em que se verificou uma viabilidade de 123,00 $\pm 11,37 \%$. Comparando-se amostras do regime de $24 \mathrm{~h}$ com diferentes concentrações, pode-se notar que a concentração de $202 \mathrm{mg} / \mathrm{mL}$ com viabilidade de $2,83 \pm 6,79 \%$; é mais citotóxica que as concentrações de $8,10 \mathrm{mg} / \mathrm{mL}(\mathrm{p}=0,008), 1,62$ $\mathrm{mg} / \mathrm{mL}(\mathrm{p}<0,0001), 324 \mu \mathrm{g} / \mathrm{mL}(\mathrm{p}<0,0001), 64,8 \mu \mathrm{g} / \mathrm{mL}(\mathrm{p}<0,0001)$ e a de 13,0 $\mu \mathrm{g} / \mathrm{mL}(\mathrm{p}<0,0001)$. O Tween-80, em si, pode apresentar uma IC 50 de 210,0 $\pm 15,0$ $\mu \mathrm{g} / \mathrm{mL}$ quando averiguado em cultura de fibroblastos, um valor mais de 100 vezes menor ao verificado nas $\mathrm{NP}(+\mathrm{T} 80)$, cuja $\mathrm{IC}_{50}$ média, desconsiderando efeitos temporais, foi de $24,12 \pm 5,22 \mathrm{mg} / \mathrm{mL}$, embora este valor tenha sido aqui verificado 
em cultura de células neuronais (ARECHABALA et al., 1999). Este dado indicaria que as NP(+T80) seriam muito menos citotóxicas que o surfactante puro.

No caso de imunolipossomos, nenhum dos tempos de aplicação da formulação de lipossomos revelou citotoxicidade quando em cultura de células Neuro-2a, assim modelos farmacológicos não foram ajustados. Quando comparados os tempos de aplicação da formulação, pode-se pressupor que o tempo de $24 \mathrm{~h}$ estaria apresentando células mais viáveis que as de outro tempo. Claramente, a formulação de lipossomos é menos citotóxica que o controle positivo de Triton empregado $\left(\mathrm{IC}_{50,24 \mathrm{~h}-\mathrm{tri}}=129 \mu \mathrm{g} / \mathrm{mL}\right.$, como previamente calculado $)$ e ainda menos citotóxica que a de nanopartículas $\left(\mathrm{IC}_{50,24 \mathrm{~h}}=15,82 \mathrm{mg} / \mathrm{mL}\right)$. As múltiplas comparações pelo teste de Holm-Šídák não evidenciaram nenhuma diferença significativa entre quaisquer amostras presentes no ensaio executado. Contudo, os resíduos acumulados na averiguação da ANOVA two-way exibem um efeito significante do tempo $(\mathrm{F}(3,140)=$ 9,0026, $p<0,0001)$ para a viabilidade celular quando da aplicação da formulação de lipossomos, mas não para as diferentes concentrações $(F(6,140)=2,0639, p=$ 0,0612). Nota-se, no entanto, a probabilidade limiar do efeito da concentração ao nível de significância de $5 \%$.

Os ensaios de citotoxicidade dos carreadores também foram conduzidos na linhagem SH-SY5Y, sendo que primeiramente avaliaram-se os efeitos das nanopartículas funcionalizadas. Neste caso, os tempos de 12 h e 24 h foram testados em uma nova faixa de concentrações. A Figura 18 revela os perfis de inibição farmacológica obtidos para a avaliação de citotoxicidade de NPs em SH-SY5Y.

Os dados de citotoxicidade revelam que a SH-SY5Y apresenta maiores viabilidades em maiores concentrações de NPs. Tanto para a curva de $12 \mathrm{~h}$, quanto para a de 24 h, a IC 50 não pôde ser obtida pelo ajuste não-linear, pois nem mesmo a maior concentração aplicada $(202,4 \mathrm{mg} / \mathrm{mL})$ atingiu valores de viabilidade para tal.

A análise estatística revela que não há, como no caso da N2a, efeito do tempo de aplicação da formulação na cultura celular $(F(1,28)=0,3118, p=0,5810)$, mas sim da concentração $(F(6,28)=11,82, p<0,0001)$. 


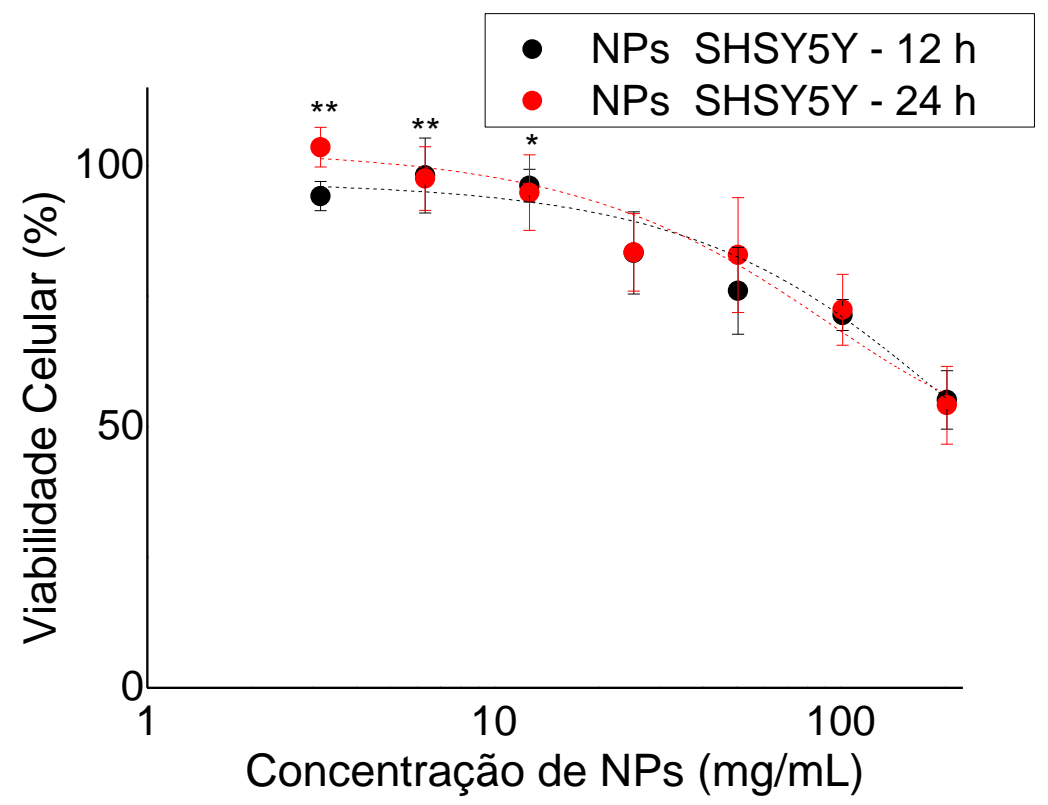

Figura 18 - Resultados dos ensaios de citotoxicidade para nanopartículas em SH-SY5Y e ajustes para as curvas farmacológicas. A curva "-" se refere à aplicação de 12 h e "--de 24 h das nanopartículas. Valores expressos como média \pm s.e.m. * $p<0,5 ;{ }^{* *} p<0,01$ vs. a concentração de $202,4 \mathrm{mg} / \mathrm{mL}$, de acordo com a análise de variância em duas vias com as múltiplas comparações realizadas pelo teste de Holm-Šídák ( $\mathrm{n}=6$, três experimentos independentes).

Frente a esta menor suscetibilidade das células SH-SY5Y às nanopartículas, a citotoxicidade dos imunolipossomos não foi testada nesta linhagem, uma vez que não revelou perfil citotóxico na linhagem Neuro-2a.

\subsection{Estudo do efeito dos carreadores sobre a entrega intracelular de um composto em células Neuro-2a e SH-SY5Y}

As primeiras análises quanto à internalização de nanopartículas e lipossomos foram realizadas em células N2a. Primeiramente, efetuou-se a aplicação dos carreadores com o fluoróforo, FITC-NPs e FITC-LPs, por $24 \mathrm{~h}$. Neste caso a marcação de pan-caderina foi utilizada, conforme exibe a Figura 19. 

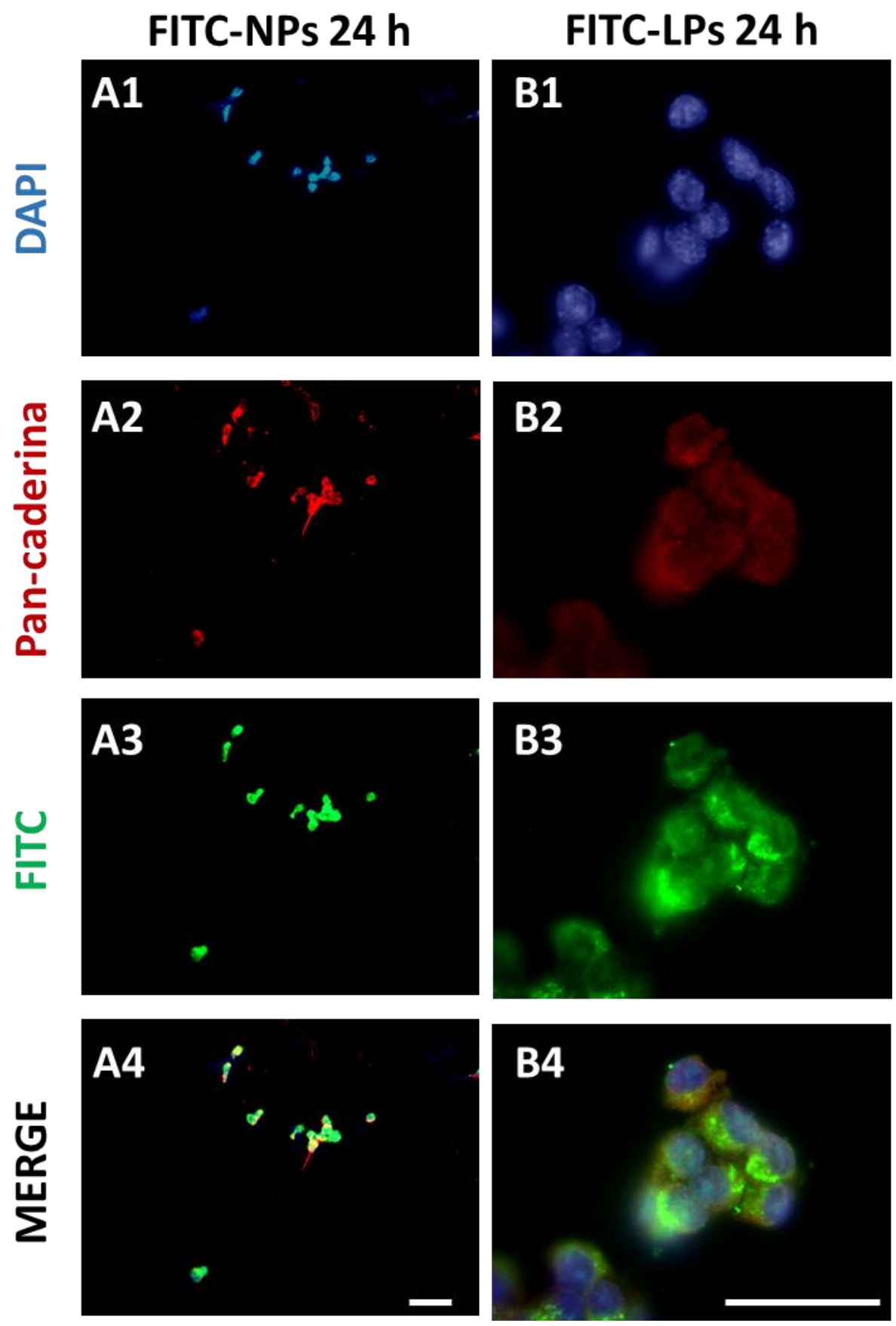

Figura 19 - Fotos de imunofluorescência para averiguação da internalização de nanopartículas e lipossomos em células N2a por 24h. As composições de 1-4 envolvem as marcações de DAPI (1), pancaderina (2), FITC (3) e a sobreposição das imagens (4). As imagens A exibem células em que FITCNPs foram aplicadas e em B, FITC-LPs. As barras de tamanhos se referem a $40 \mu \mathrm{m}$.

Pode-se averiguar que em $24 \mathrm{~h}$ de aplicação das formulações ocorre internalização dos carreadores, quer das nanopartículas ou dos lipossomos. Selecionou-se a pan-caderina como um marcador de membrana, mas sua marcação não se revelou ideal, como observado nas imagens, quer devido à expressão da 
proteína pelas células ou pelo próprio anticorpo empregado. Desta forma, a marcação foi modificada para $\beta$-actina e reduziu-se o tempo de aplicação dos carreadores para avaliação de um perfil cinético de internalização. A Figura 20 exibe os resultados para internalização de FITC-NPs e FITC-LPs em 6 h em Neuro-2a, bem como de controles não fluorescentes destes carreadores. 

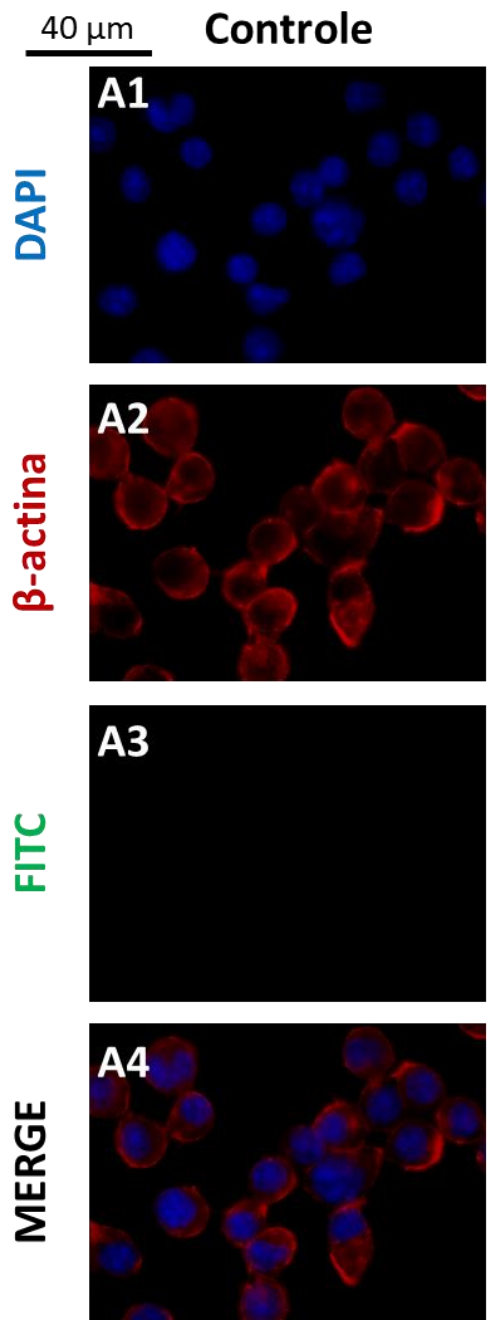
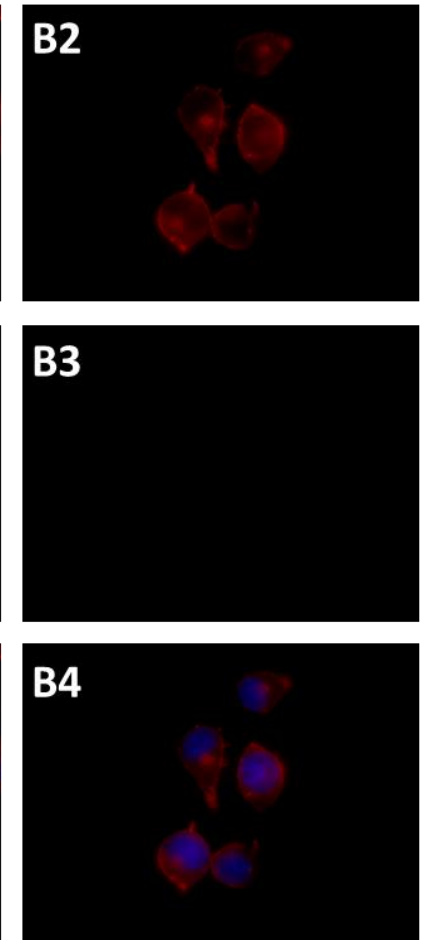

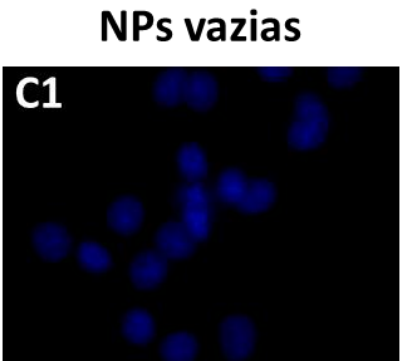

FITC-NPs $6 \mathrm{~h}$
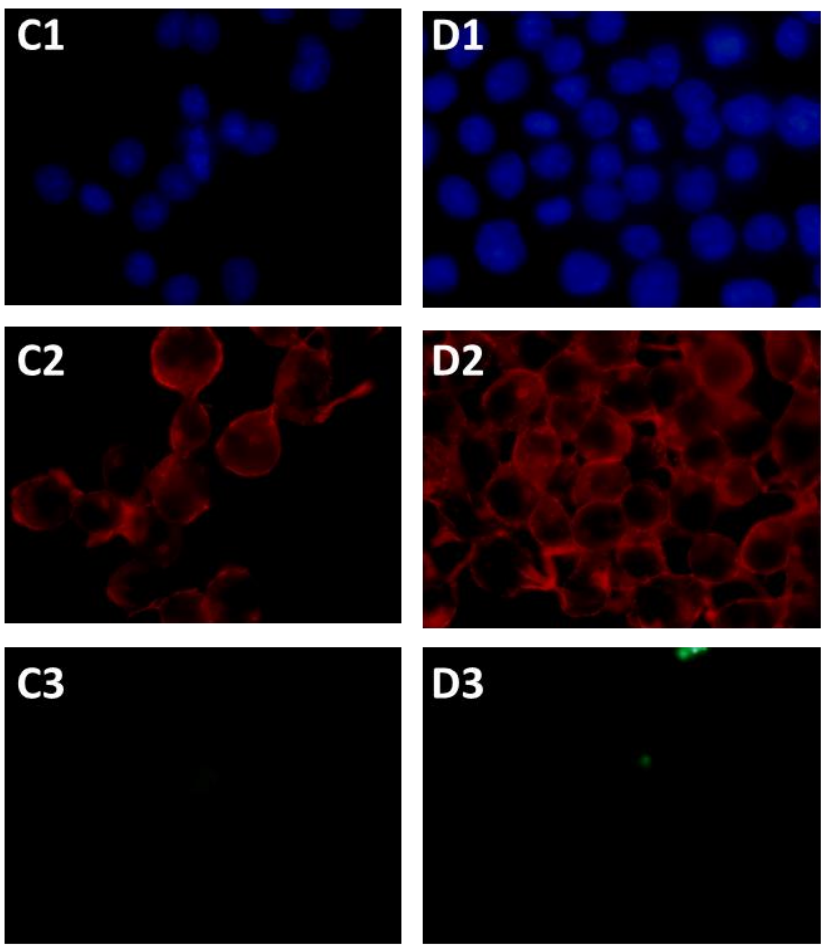

C4

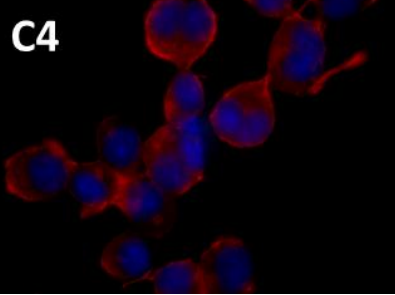

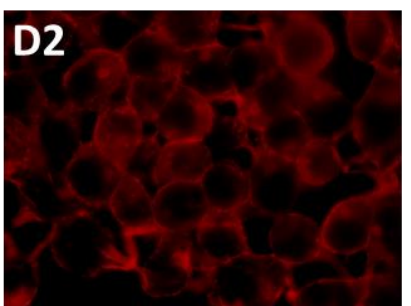

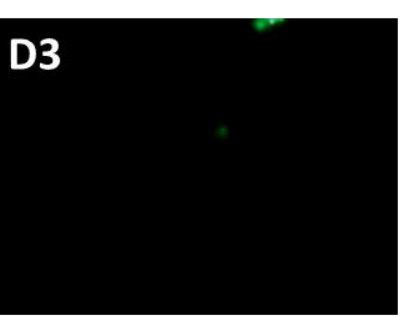

D4

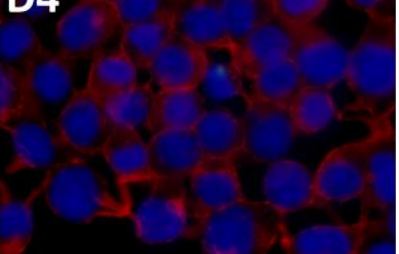

FITC-LPs $6 \mathrm{~h}$
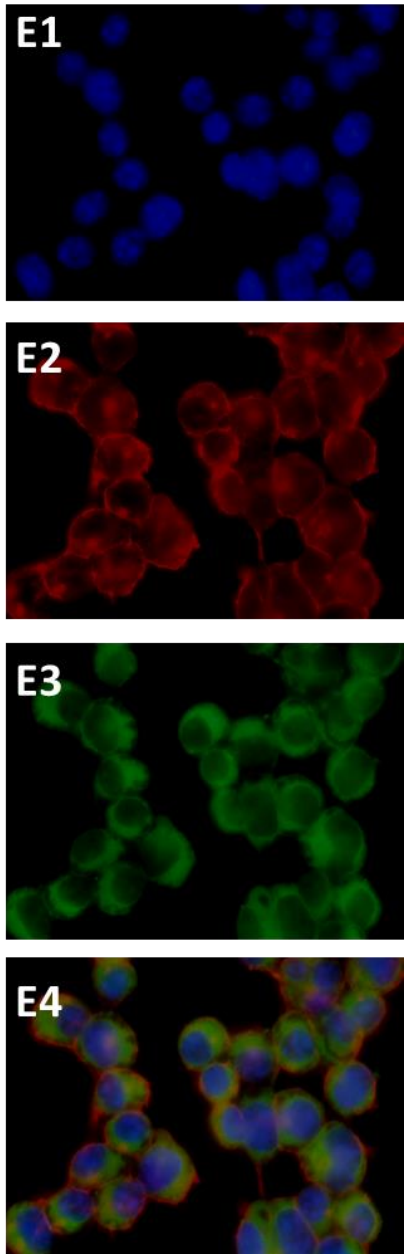

Figura 20 - Fotos de imunofluorescência para averiguação da internalização de nanopartículas e lipossomos por 6 h em células N2a. As composições de 1-4 envolvem as marcações de DAPI (1), $\beta$-actina (2), FITC (3) e a sobreposição das imagens (4). As imagens A exibem controles de células sem aplicação. Em $\mathbf{B}$, tem-se a marcação de células que passaram pela aplicação de imunolipossomos vazios; em $\mathbf{C}$ houve a marcação de células com a aplicação de nanopartículas vazias; em D aplicaram-se lipossomos contendo FITC (FITC-LPS) e em E, nanopartículas com FITC encapsulado (FITC-NPs). 
Pôde-se observar que nenhum dos controles, isto é, quer as células sem aplicação ou com os nanocarreadores vazios, revelou algum efeito de autofluorescência no filtro da FITC na averiguação em microscopia de fluorescência. Para o caso da aplicação de FITC-NPs ou de FITC-LPs a fluorescência foi observada neste filtro, mas a internalização em $6 \mathrm{~h}$ nesta linhagem só pôde ser efetivamente constatada para o caso dos FITC-LPs. Tal internalização, como pode ser observada, é substancial. Contudo, nota-se que a morfologia das células neuronais murinas (N2a) não revelava característica de uma célula plenamente diferenciada. Portanto, os testes de internalização também foram efetuadas na linhagem SHSY5H.

A aplicação das formulações fluorescentes (FITC-NPs e FITC-LPs) foi realizada em cultura de células SH-SY5Y durante diferentes períodos. As imagens na Figura 21 foram obtidas por microscopia de fluorescência e permitem visualizar a cinética de internalização de tais formulações. 

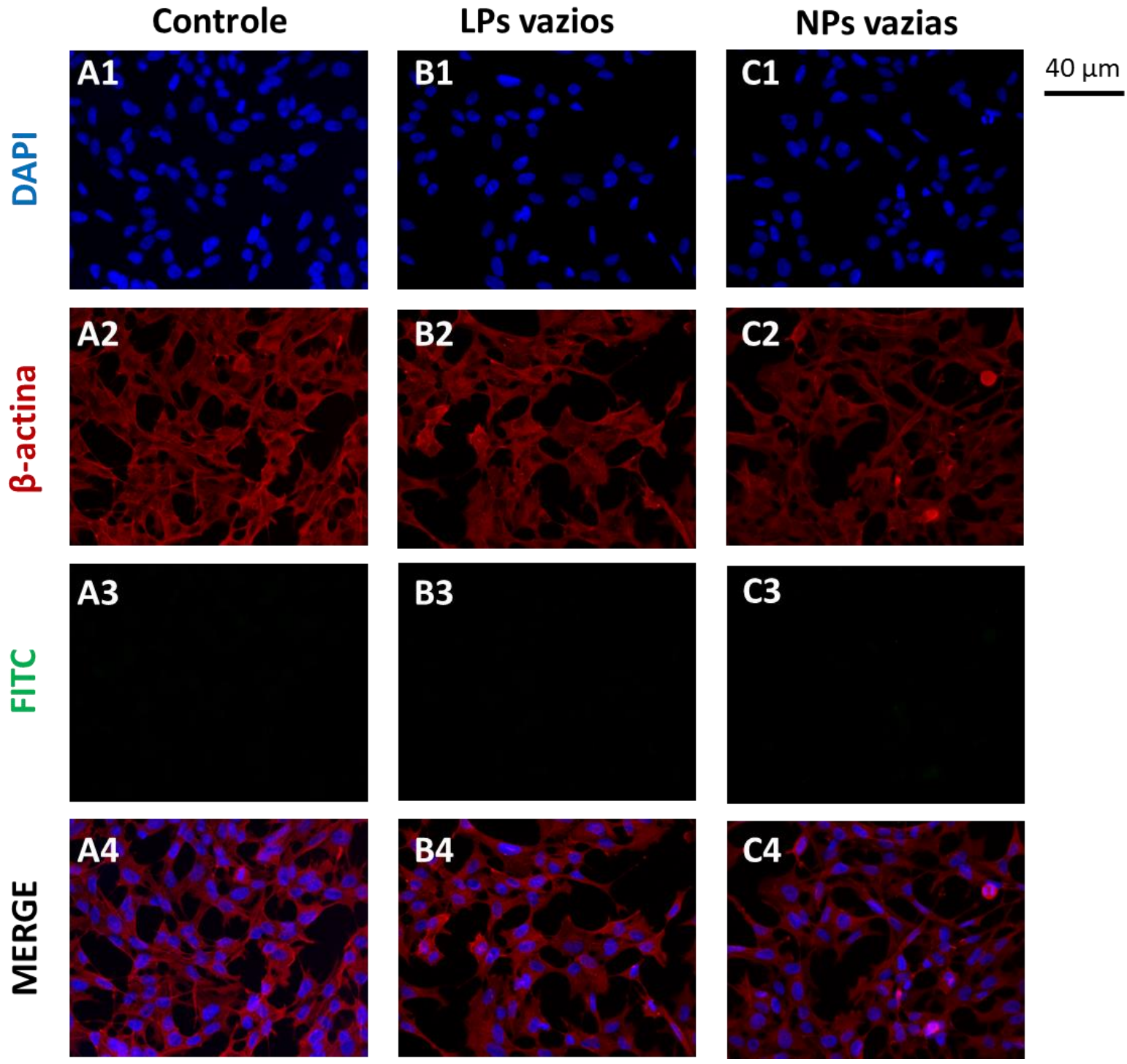

Figura 21 (ver continuação) - Fotos de imunofluorescência exibindo controles em células SH-SY5Y. As composições de 1-4 envolvem as marcações de DAPI (1), $\beta$-actina (2), FITC (3) e a sobreposição das imagens (4). As imagens $\mathbf{A}$ exibem controles de células sem aplicação. Em $\mathbf{B}$, tem-se a marcação de células que passaram pela aplicação de imunolipossomos vazios após $30 \mathrm{~min}$; e em $\mathbf{C}$ houve a marcação de células cuja a aplicação de nanopartículas vazias foi realizada por $12 \mathrm{~h}$. 

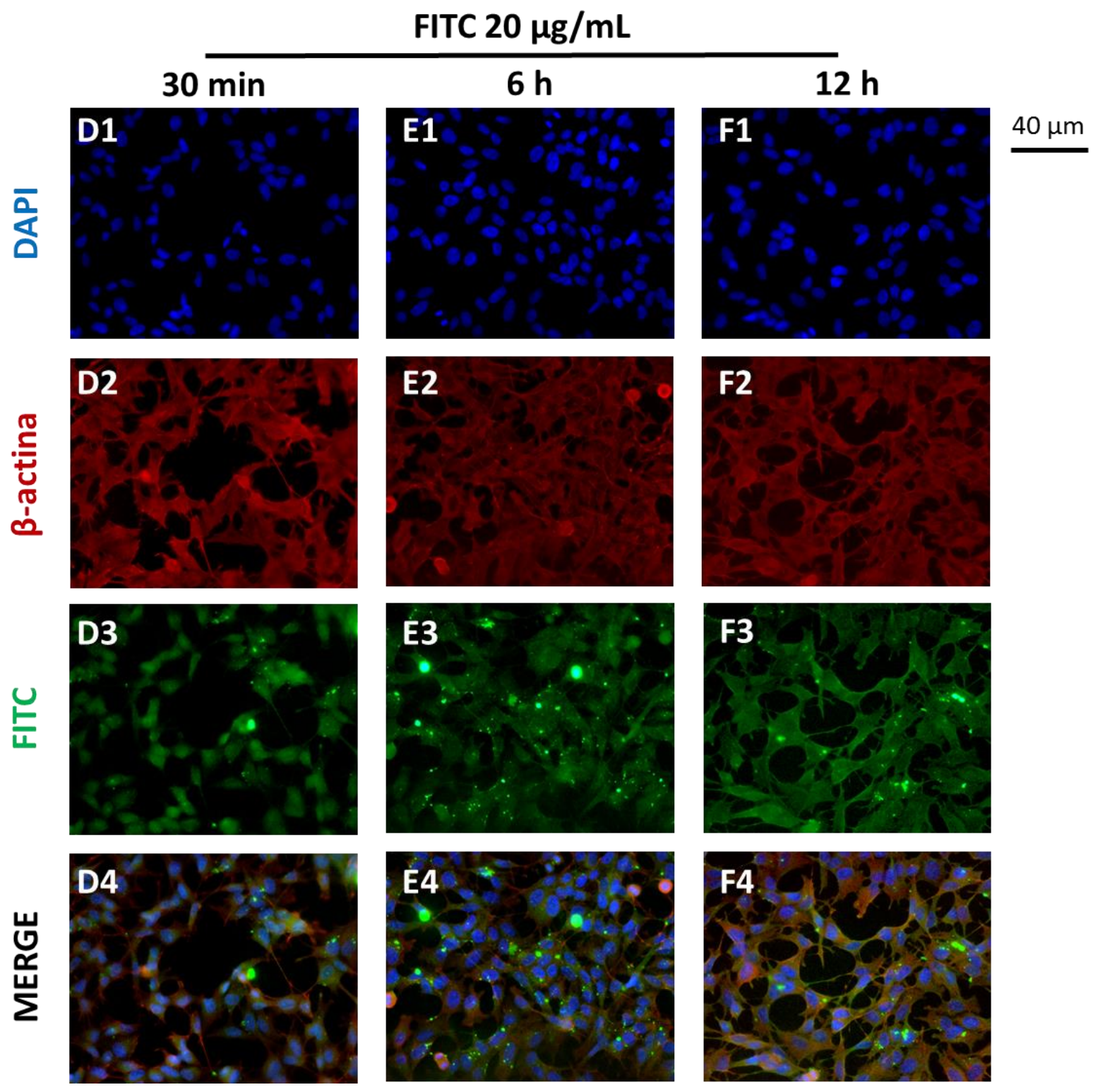

Figura 21 (ver continuação) - As imagens D-F revelam marcações de células que passaram pela aplicação do controle de $20 \mu \mathrm{g} / \mathrm{mL}$ de FITC ao meio de cultura por $30 \mathrm{~min}, 6 \mathrm{~h} \mathrm{e} 12 \mathrm{~h}$ respectivamente. 

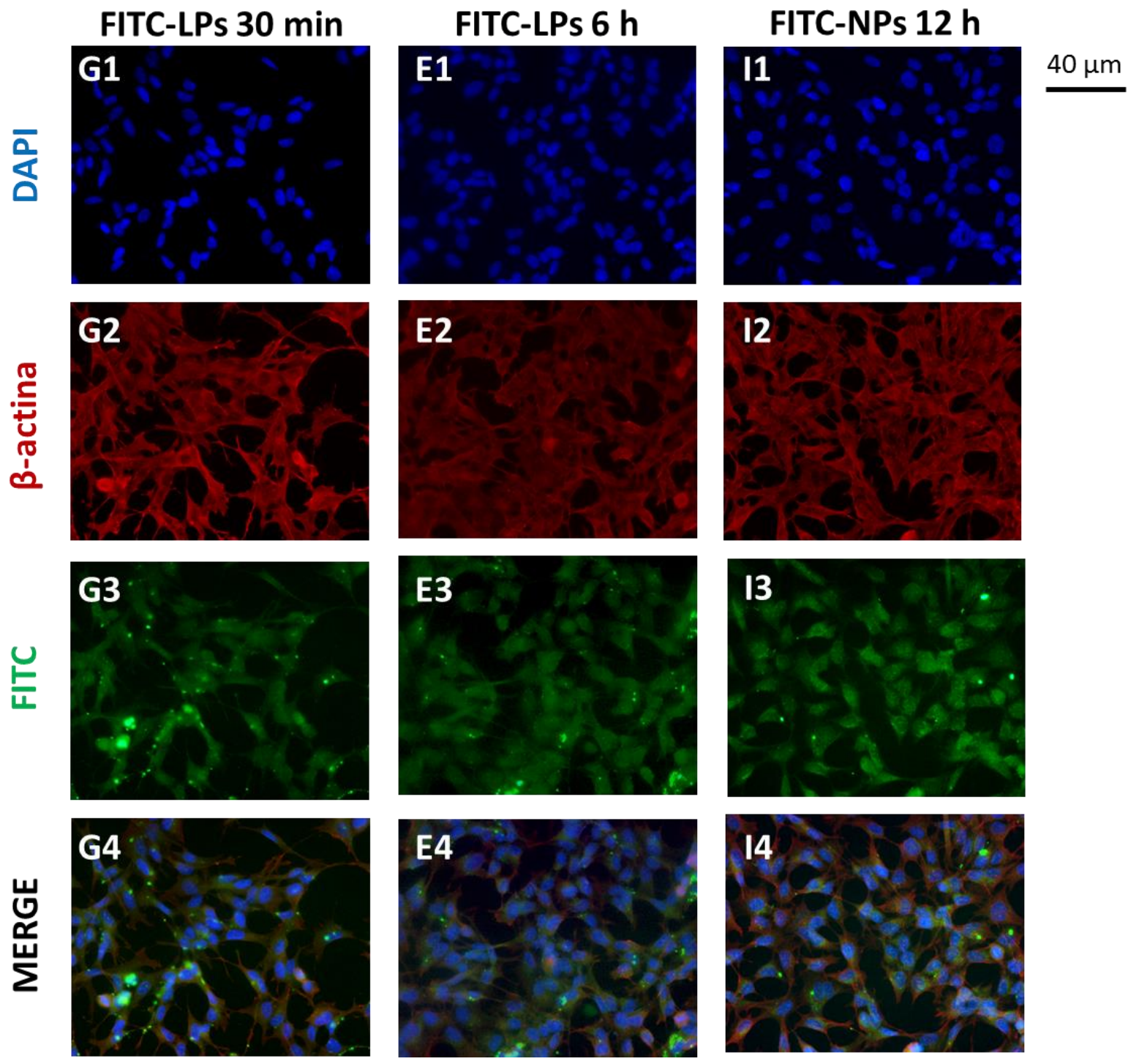

Figura 21 - As imagens $\mathbf{G}$ e $\mathbf{H}$ revelam marcações de células que passaram pela aplicação FITC-LPs por 30 min e 6 h, respectivamente; e I consiste em células tratadas com FITC-NPs por $12 \mathrm{~h}$.

Os controles, tanto sem aplicação de formulação, com lipossomos ou nanopartículas não revelou aspectos de autofluorescência utilizando filtro para FITC. A internalização de lipossomos pode ser verificada de forma mais pronunciada em 30 min, comparado à FITC em solução. Mas em 6 h, a aplicação de FITC em solução resulta em marcação semelhante aos FITC-LPs. Nanopartículas não revelam considerável internalização dentro de $12 \mathrm{~h}$. 


\section{DISCUSSÃO}

Nanocarreadores são ferramentas capazes de transportar substâncias de interesse a sítios específicos. Para o caso do tratamento e prevenção de doenças no SNC tais sistemas são de extrema valia, já que diversos fármacos não desenvolvem a ação central desejada por não transporem a BHE. O desenvolvimento de nanocarreadores otimizados, isto é, que possuam uniformidade de tamanho, melhor estabilidade eletrostática e tamanho reduzido; além de serem internalizados por células neuronais e apresentarem citotoxicidade reduzida, conforme demonstrado neste trabalho, é essencial para que a atividade biológica - a de sítio-direção ao SNC - seja então satisfeita.

O teste fatorial $2^{2}$ realizado com nanopartículas vazias permitiu avaliar o efeito do volume de ressuspensão de T-80 e do tamanho da barra de agitação em variáveisresposta como tamanho e potencial zeta dos particulados. A interação entre o volume de ressuspensão e o tamanho da barra de agitação influem no tamanho das partículas, sendo que quando se atinge o menor subnível desta interação, obtém-se menores tamanhos de nanopartículas. O potencial zeta, por sua vez é efetado por ambas as variáveis e pela interação entre elas. O uso de um menor volume de ressuspensão de polissorbato-80 e da maior barra magnética utilizada influem para um potencial zeta mais negativo. Valores menores da interação entre as duas variáveis averiguadas também proporcionam um potencial zeta mais negativo.

Considerando todas estas constatações, pode-se notar que a seleção do menor subnível da variável $A$ e o maior da variável $B$, isto é, ressuspender o pellet de nanopartículas em $1 \mathrm{~mL}$ de T-80 e utilizar a barra magnética de $10 \times 8 \times 8 \mathrm{~mm}$; proporcionaria resultados mais satisfatórios dos particulados confeccionados. Neste quadro $[\mathrm{A}(-), \mathrm{B}(+)]$, tem-se a de minimização do tamanho dos particulados associada à interação $A B$ e à variável $A$. $O$ potencial zeta apresentou valores mais negativos tanto pelo efeito da variável $A$, como pelo da interação $A B$, contudo estaria sendo prejudicado pela escolha do subnível (+) da variável B. Ressalta-se, no entanto, que o efeito combinado da variável $A$ e da interação $A B$ são suficientes para suplantar o da variável $B$, neste caso, conforme verificado na Tabela 3 , e proporcionar resultados mais satisfatórios que de uma combinação distinta de subníveis. Surfactantes nãoiônicos, como o polissorbato-80, se adsorvem ao substrato por adsorção física, em 
que há interações de van der Waals entre o adsorvente-adsorbato, e não por interações eletrostáticas (SANTHANALAKSHMI; BALAJI, 1996). Distintamente de surfactantes iônicos, sua adsorção é substancialmente afetada por modificações de concentração, temperatura, ou estrutura molecular do adsorvente, quer por interações adsorbato-adsorbato ou adsorbato-solvente (PARIA; KHILAR, 2004). Desta forma, acredita-se que a modificação do volume ou da forma com que a agitação foi realizada possam estar alterando aspectos como os citados, afetando a maneira com a qual o tensoativo efetivamente se associa aos particulados.

$\mathrm{Na}$ avaliação das nanopartículas confeccionadas, pôde-se perceber um leve aumento de seu tamanho ao longo do processo de obtenção. Esta ocorrência era esperada, uma vez que existem duas etapas de centrifugação, as quais favorecem a formação de aglomerados de partículas. Contudo, tal processo não afeta consideravelmente o PDI. O potencial zeta, por sua vez, é fortemente afetado quando da ressuspensão do pellet de nanopartículas em T-80, uma vez que a adsorção por este tensoativo condiciona a uma inversão do potencial se comparado com uma ressuspensão aquosa. Os sais de amônio, quer o DMAB ou o DDAB, são altamente catiônicos e a inversão do potencial poderia refletir no recobrimento da superfície das nanopartículas pelo polissorbato-80, um tensoativo com características neutras (BHARDWAJ et al., 2009). Nossas nanopartículas apresentaram um potencial zeta negativo, uma evidência que é recorrente em nanopartículas poliméricas recobertas com o polissorbato-80, como já foi constatado anteriormente em partículas constituídas por PLGA ou de polibutilcianoacrilato (PBCA) (GIROTRA; SINGH, 2016; MIYAZAWA et al., 2015).

É possível verificar que há diferença entre os regimes de sonicação em relação a carga superficial, especialmente quando se observa que para os pulsos de 50 segundos há uma inversão de potencial zeta mais clara que para o regime de pulsos de 30 segundos. Neste caso, considera-se que um potencial zeta não tão próximo da nulidade é benéfico em termos da estabilidade da formulação. No processo em que se empregou o regime envolvendo pulsos de 30 segundos, embora se verifique a inversão de potencial, estes são menos negativos que no caso do processo em que se empregou pulsos de 50 segundos, tornando este mais vantajoso. O tempo de sonicação total pode resultar numa mudança da carga superficial, uma vez que existe, decorrente deste processo físico, uma alteração da química superfícial das partículas. 
A sonicação não só contribui para o rompimento de agregados, mas para a ocorrência de processos de oxidação e hidroxilação de grupos presentes na amostra; hipotetizamos que este fato pode ocasionar uma adsorção diferencial do T-80 entre tratamentos diferenciais (TAUROZZI et al., 2011).

No que tange a comparação entre o uso de tensoativos para emulsificação (DMAB e DDAB), não se averiguou uma diferença estatística significativa que diferencie claramente as partículas formadas entre os tratamentos. Como exposto anteriormente, existe pequena diferença entre tais sais de amônio: duas cadeias carbônicas ligadas ao grupo amônio do DMAB apresentam dois carbonos a mais que no caso do DDAB. A maior lipofilicidade do DMAB em relação ao DDAB poderia resultar em um padrão de melhor formação dos emaranhados poliméricos (COOPER; HARIRFOROOSH, 2014). Apenas uma tendência de PDI e potenciais zetas mais negativos foi verificada e por esta razão decidiu-se realizar os testes futuros com 0 DMAB.

Nanopartículas com FITC apenas apresentam um aumento de tamanho, mas não se revelaram mais polidispersas. Estas partículas apresentaram uma tendência substancial em possuir uma carga superficial mais negativa que nanopartículas vazias. A FITC apresenta cargas negativas em pH fisiológico; portanto, espera-se que haja uma eventual redução do potencial zeta pelo seu encapsulamento. $O$ aumento de tamanho após o encapsulamento ocorre comumente com nanopartículas, especialmente, no caso de compostos lipofílicos (BARICHELLO et al., 1999). A FITC é considerada um composto levemente lipofílico, apresentando logP em torno de 0,85 , fato que pode justificar, em parte, este aumento de tamanho da nanopartícula pela lipofilicidade da fluorescina (GOMAA et al., 2012).

O imageamento em microscopia de varredura com emissão de campo teve o objetivo de averiguar tanto o aspecto morfológico como o físico-químico dos particulados. Nanopartículas sem o polissorbato-80 apresentaram-se dispersas após a fixação no stub, além de possuírem um tamanho menor e um potencial zeta altamente catiônico, em decorrência do DMAB. Partículas cujo T-80 foi adsorvido apresentaram-se agregadas após a fixação, possuindo maior tamanho e potencial zeta negativo, embora em menor módulo que as partículas sem o tensoativo. O que se pode supor é uma menor estabilidade das NPs(+T80), de modo que estas estão sujeitas a se agregar após um protocolo de fixação, como o realizado. Entretanto, tal 
fato não foi verificado antes da realização do procedimento, conforme revelam as distribuições de tamanho e potencial zeta deste grupo. Sabe-se que a redução do volume dispersante, como ocorreu no processo para a fixação das nanopartículas à lamínula para MEV-FEG, pode contribuir para a formação de agregados, uma vez que aumenta, consequentemente, a concentração dos particulados (SMOLUCHOWSKI, 1917).

A primeira etapa para a caracterização de lipossomos envolveu o ensaio da cinética de formação das vesículas. Testou-se o mesmo procedimento para lipossomos formados com DPPC e DOPC de modo a averiguar comportamentos distintos entre as composições. Lipossomos de DPPC atingem um patamar de tamanho em sonicações posteriores a lipossomos de DOPC e este fato pode ser explicado pela temperatura de transição das fosfatidilcolinas. O processo de sonicação promove um aumento de temperatura e este acaba sendo mais eficiente quando os lipídeos estão acima de sua temperatura de transição: o DOPC apresenta uma temperatura de transição mais baixa $\left(T_{m, D O P C}=-22{ }^{\circ} \mathrm{C}\right)$ que o DPPC $\left(T_{m, D P P C}=\right.$ $41^{\circ} \mathrm{C}$ ) e o sistema atinge sua conformação mais estável de maneira mais rápida (SZOKA; PAPAHADJOPOULOS, 1980).

No caso do PDI, o mesmo padrão assintótico que ocorre no caso do tamanho está presente no caso de lipossomos de DPPC. Pode-se concluir que os adicionais processos de sonicação claramente minimizam o tamanho das vesículas ao ponto de se atingir sua melhor conformação. No entanto, no caso de lipossomos com DOPC, a mesma configuração não se verifica. Um mínimo da polidispersidade é atingido, sendo que valores crescentes são obtidos com sonicações adicionais. Pode-se inferir que a forma mais estabilizada de lipossomos realmente é obtida precocemente, se comparada aos lipossomos de DPPC; as sonicações adicionais, acabaram promovendo sua aglomeração, processo denominado de coagulação, mas de forma não-significativa a alterar valores de tamanho (AOKI, 1987). Tal fato poderia estar associado à presença de aglomerados grandes juntamente com vesículas pequenas, mantendo um tamanho médio uniforme, mas um PDI maior.

A próxima análise se deu com lipossomos de DPPC em diferentes averiguações sequenciais de tratamento. Em primeiro lugar, pôde-se notar que não existe distinção se a evaporação do solvente para formação do filme lipídico ocorre por controle da temperatura e agitação ou de sua realização em um ambiente a vácuo. 
A filtração de lipossomos em filtro de poro de 0,45 $\mu$ m é, como já esperado, uma etapa de nivelação de tamanho das vesículas, uma vez que reduz consideravelmente o PDI. Ademais, apenas após a centrifugação mais intensa do grupo em que o tratamento a vácuo fora realizada seria capaz de revelar uma redução do potencial zeta em relação à primeira medição. Conforme hipotetizado por Roca e colaboradores, submeter uma mistura coloidal a uma elevada força centrífuga pode, por ventura, causar polarização das duplas camadas elétricas dos elementos dispersos, promovendo a formação de agregados estáveis. Acredita-se que a formação de agregados possa ter contribuído de tal forma a se apresentar como o grupo de menor potencial zeta médio revelado (ROCA et al., 2010).

Por outro lado, um processo de centrifugação mais branda com a finalidade de retirar o dióxido de titânio da formulação de lipossomos, um metal pesado, relacionado a inflamação e genotoxicidade, mostrou um efeito oposto da carga superficial em lipossomos de DOPC, isto é, um aumento (SKOCAJ et al., 2011). Este fato não ocorre com lipossomos de DPPC. Pode-se intuir que lipossomos de DOPC apresentam uma menor estabilidade frente ao estresse gravitacional, ocasionando a confluência das vesículas e a aproximação do potencial zeta a valores mais nulos. Presume-se que a maior fluidez das vesículas de lipossomos de DOPC à temperatura ambiente, decorrente da menor $T_{m}$ deste lipídeo, pode facilitar a aglomeração das vesículas, causando a alteração de carga superficial verificada. Lipossomos de DPPC, por outro lado, mais rígidos nas mesmas condições, não se aglomerariam com tanta facilidade na centrifugação mais branda. Por outro lado, ocorre a precipitação dos particulados de dióxido de titânio e das vesículas e agregados de maior tamanho em ambos os casos. No entanto, como a agregação foi mais propícia em lipossomos com DOPC, não se averiguou a redução de PDI neste sistema, mas sim no com DPPC (YADAV, 2011). Embora após o processo de centrifugação branda lipossomos de DOPC apresentem um leve aumento do potencial zeta e não revelem uma diminuição do PDI, eles apresentaram menores tamanhos durante a caracterização da cinética de formação de lipossomos e consideramos que para um sistema transpor a barreira hematoencefálica, esta característica deve ser primeiramente considerada.

Diferentemente do que averiguado no caso de FITC-NPS, FITC-LPs não apresentaram nenhuma variação quer, em tamanho, PDI ou potencial zeta. Chang e colaboradores realizaram o encapsulamento de FITC-BSA em lipossomos com di- 
estearoilfosfatidilcolina (DSPC) com injeção por extrusão. Vesículas vazias, possuindo tamanho de $125 \pm 2 \mathrm{~nm}$ e potencial zeta de $-12,4 \pm 1,5 \mathrm{mV}$, não diferiram significativamente daquelas com o fluoróforo encapsulado, cujos lipossomos marcados apresentaram tamanho médio de $126 \pm 5 \mathrm{~nm}$ e potencial zeta de $-13,7 \pm$ 1,4 mV. Neste caso o PDI não foi alterado, situando-se em ambos os casos em torno de 0,2 (CHANG et al., 2011).

No caso da citotoxicidade, constatou-se que o tempo não estava associado ao efeito citotóxico dos nanocarreadores. Nanopartículas sem o polissorbato-80 apresentam baixa toxicidade. Semete e colaboradores averiguaram a viabilidade em células HeLa e Caco-2 após a administração de 1, 10 e 100 g/mL de nanopartículas de PLGA. Neste caso a concentração para determinação da $I_{50}$ não foi atingida (SEMETE et al., 2010). Pudemos determinar o caráter citotóxico de NP(+T80). Em células Neuro-2a, a citotoxicidade apenas não é verificada em concentrações inferiores a $324 \mu \mathrm{g} / \mathrm{mL}$. No entanto, Arechebala e colaboradores obtiveram uma IC $\mathrm{C}_{50}$ de $210,0 \pm 15,0 \mu \mathrm{g} / \mathrm{mL}$ para o polissorbato-80 em cultura de fibroblastos, um valor mais de 100 vezes menor do que o obtido para as NP(+T80), indicando que as nanopartículas recobertas com T-80 são bem menos citotóxicas que o surfactante em si. Acredita-se que os resultados são comparáveis observando a $\mathrm{IC}_{50}$ que obtivemos para o Triton com a que o grupo obteve, principalmente considerando a mudança do tipo celular: nós obtivemos uma $\mathrm{IC}_{50}$ de $128 \mu \mathrm{g} / \mathrm{mL}$ para o Triton, enquanto Arechebala e colaboradores calcularam 41,0 $\pm 5,0 \mu \mathrm{g} / \mathrm{mL}$ para o composto (ARECHABALA et al., 1999). A citotoxicidade das nanopartículas também foi testada em células SH-SY5Y, uma vez que as células N2a testadas não revelaram uma morfologia considerada ideal. Células da linhagem SH-SY5Y revelaram ser menos suscetíveis ao aspecto citotóxico das partículas e a $\mathrm{IC}_{50}$ não pôde ser calculada nem para as maiores concentrações testadas. Ademais, a viabilidade plena das células após a administração da formulação ocorre com concentrações de $12,7 \mathrm{mg} / \mathrm{mL}$ de NPs, um valor 39,2 vezes maior que o verificado no caso da Neuro-2a.

Lipossomos, por outro lado, não evidenciaram qualquer caráter citotóxico na cultura de neuroblastoma murino e, por esta questão o ensaio não foi realizado em células SH-SY5Y, que demonstraram ser menos lábeis que a N2a. O caráter da nãocitotoxicidade dos lipossomos era esperado e deriva de sua grande biocompatibilidade 
e biodegradabilidade por possuírem, dentre outros, elementos próprios da membrana celular (BOZZUTO; MOLINARI, 2015).

Estas considerações possibilitaram realizar o teste de internalização de nanopartículas e lipossomos. Primeiramente verificou-se se os carreadores eram internalizados após $24 \mathrm{~h}$ de aplicação em células Neuro-2a. A internalização foi constatada tanto para nanopartículas como para lipossomos, mas devido a questões de marcações para pan-caderina, decidiu-se modificar a marcação para $\beta$-actina e reduziu-se o tempo de incubação para $6 \mathrm{~h}$, de forma a avaliar o aspecto cinético da internalização. Nesta instância, a internalização só foi averiguada com lipossomos, e não mais com nanopartículas. A realização do imageamento utilizando controles com células sem formulação aplicada ou com a aplicação das formulações de nanopartículas ou de lipossomos vazios teve a finalidade de averiguar a presença de efeitos de autofluorescência no filtro utilizado para FITC e também para estabelecer um tempo de exposição máximo, o qual foi fixado em $80 \mathrm{~ms}$. Neste experimento, constatou-se que o aspecto morfológico das células Neuro-2a estava insatisfatório: as células mostravam-se arredondadas e sem neuritos visíveis. Devido ao aspecto morfológico de células Neuro-2a, optou-se por avaliar a internalização em células SHSY5Y também, as quais demonstraram um caráter morfológico próprio a uma linhagem neuronal. É conhecido o fato de que células de neuroblastoma diferenciadas estão associadas com mecanismos de resistência a fármacos, como por exemplo, à perda da resposta apoptótica sugerida pela superexpressão do gene BCL2 (LASORELLA et al., 1995). Este fato pode estar relacionado com nossos resultados de citotoxicidade das nanopartículas distintos nas linhagens N2a e SH-SY5Y, em que a primeira demonstrou ser mais lábel e a segunda menos.

Neste novo ensaio de internalização, agora na linhagem SH-SY5Y empregaram-se, além de controles com carreadores vazios, uma segunda série de controles, envolvendo o uso de FITC em solução na concentração de $20 \mu \mathrm{g} / \mathrm{mL}$, de forma a comparar a internalização do composto não encapsulado com o encapsulado com os nanocarreadores. Esta concentração do fluoróforo foi estabelecida com base numa aproximação em testes de encapsulamento preambulatórios realizados, em que se constatou que entre $10-20 \%$ deste fluoróforo permaneciam nos carreadores.

No que tange os controles com a FITC em solução, pode-se constatar que existe uma crescente internalização do fluoróforo em aspecto temporal, tendo-se a 
internalização máxima verificada em 12 h. Contudo, o emprego de nanocarreadores com FITC encapsulado modifica esta cinética. Lipossomos favoreceram a internalização de FITC até 30 min em comparação com o fluoróforo em solução, mas em 6 h esta relação não persiste. Em contrapartida, nanopartículas não revelaram internalizar a FITC tão prontamente quanto lipossomos ou quanto o fluoróforo em solução até $12 \mathrm{~h}$, mas as nanopartículas já revelaram ser plenamente internalizadas em 24 h. Wang e colaboradores estudaram a cinética de internalização de nanopartículas de PLGA em células MC3T3-E1, uma linhagem de osteoblastos murinos. O grupo verificou que a internalização deste tipo de nanopartículas é crescente até o tempo de $24 \mathrm{~h}$, maior tempo analisado (WANG et al., 2015). Du e colaboradores, por outro lado, avaliaram a internalização de lipossomos estericamente estabilizados em B16-F10, células de melanoma murino. Foi-se constatado que a máxima internalização das vesículas, vista em microscopia em tempo real, ocorria em um tempo próximo a 7 min (DU et al., 2014). Pode-se verificar, claramente, que em testes in vitro, nanopartículas poliméricas possuem um mecanismo mais lento de terem seu conteúdo internalizado ou serem elas mesmas internalizadas, diferentemente do que ocorre com lipossomos. Este fato pode decorrer da grande biossimilaridade que lipossomos possuem com elementos da membrana celular, facilitando o mecanismo de entrega quando em contato direto com a célula (SANDRA; PAGANO, 1979).

Ambos os nanossistemas aqui desenvolvidos foram concebidos segundo a via de administração intravenosa. Existem fatores que poderiam influir negativamente no carreamento por estes sistemas já em circulação, como a sua remoção por células do sistema mononuclear fagocitário ou a associação do carreador com proteínas plasmáticas (SALMASO; CALICETI, 2013). Contudo o tamanho reduzido dos sitemas reduz a sua remoção por células do sistema imune, enquanto que funcionalizações, como o PEG associado aos imunolipossomos, coibem a agregação do carreador a proteínas plasmáticas (WALKEY et al., 2012). Outras vias de administração para nanocarreadores, como a oral, tópica e intranasal já foram desenvolvidas, mas requerem certas modificações específicas no processo de síntese (MARTINBANDERAS et al., 2012; ZHANG et al., 2013; ZHENG et al., 2015).

Nós otimizamos a síntese de nanopartículas poliméricas quanto ao tipo de tensoativo empregado na emulsificação, ao tempo de sonicação e, na etapa de 
adsorção do polissorbato-80, avaliamos os efeitos do volume deste surfactante e do tamanho da barra de agitação empregada para obtenção de partículas que consideramos ótimas. Outras variáveis do processo podem ser investigadas, como o tipo de solvente orgânico utilizado para solubilizar o PLGA que, embora neste caso tenha sido empregado o acetato de etila, inúmeros outros, como propileno carbonato, diclorometano, acetona, tetraidrofurano, bem como misturas deles, poderiam ter sido empregadas (KIM et al., 2012; SONG et al., 2006). Ademais, outro tensoativo utilizado no processo de emulsificação, que já citamos mas que não comparamos é o próprio PVA. Por fim, uma outra varíavel que fixamos foi a concentração deste tensativo, estabelecida em $1 \%(\mathrm{~m} / \mathrm{m})$. Pode-se, também alterar esta proporção de modo a averiguar um eventual ponto ótimo distinto nas variáveis-resposta avaliadas.

Vários são os fármacos que podem ser encapsulados nos sistemas desenvolvidos de forma a proporcionar aspectos de prevenção e tratamento das mais diversas doenças associadas ao SNC. Nós, por exemplo, encapsulamos em ambos os sistemas o G-1, o agonista seletivo do receptor de estrógeno acoplado à proteína G (GPER-1), cuja sinalização estaria associada à neuroproteção, quer devido às capacidades anti-inflamatórias do fármaco, ou ainda por aquelas antineoplásicas (BRUNSING et al., 2013; CHIMENTO et al., 2015; ITOGA et al., 2015; RODRIGUES, 2015; WEl et al., 2014; ZHANG et al., 2015). Uma área promissora em que a farmacoterapia poderia ser potencializada pelos nanocarreadores desenvolvidos é a das epilepsias. O encapsulamento de fármacos como tiagabina, lamotrigina e levetiracetam poderia, por ventura, maximizar os efeitos antiepilépticos e minimizar efeitos adversos como tontura, sonolência; ou fatos como teratogenecidade e indução de enzimas CYP do citocromo P450 (FRESTA et al., 1996). No âmbito das doenças neurodegenerativas inúmeras são as possibilidades de fármacos a serem encapsulados: os inibidores da catecol o-metiltransferase (COMT) e agonistas dopaminérgicos no caso da Doença de Parkinson; donepezila e rivastigmina no da Doença de Alzheimer; riluzol para a esclerose lateral amiotrófica (ELA); dentre outros. O encapsulamento poderia promover a eficácia destes fármacos, reduzindo concomitantemente os efeitos adversos associados e possibilitando melhor prognóstico ao paciente. Opções ainda mais robustas, buscando propiciar um tratamento, poderiam versar, por exemplo, no encapsulamento do anticorpo monoclonal aducanomab para a Doença de Alzheimer, capaz de reduzir os depósitos 
de placas $\beta$-amilóide (SEVIGNY et al., 2016); ou de certos flavonóides, como os da Pueraria, que apresenta propriedades de neuroproteção frente à isquemia cerebral (WANG et al., 2006). Ademais, citam-se possíveis fármacos como paclitaxel e doxorrubicina, que poderiam ser utizados para o tratamento de gliomas de alto grau (DRAPPATZ et al., 2013; HAU et al., 2004).

Em síntese, ambos os nanocarreadores puderam ser otimizados e comparados quanto à sua aplicabilidade em células neuronais, revelando claras distinções quanto a padrões de internalização e citotoxicidade; bem como de propriedades físicas tais quaisl tamanho e carga superficial com base nas técnicas empregadas. A otimização da confecção de tais carreadores, bem como a melhor compreensão de suas características são essenciais para melhor manipular sua função central como elementos de transposição da barreira hematoencefálica. 


\section{CONCLUSÕES}

Com base nos resultados da presente dissertação é possível concluir que tanto os imunolipossomos como as nanopartículas otimizadas são internalizadas por células do sistema nervoso central.

Nanopartículas poliméricas otimizadas, conforme averiguamos, seriam aquelas sintetizadas utilizando um regime de sonicação de 5 pulsos de $50 \mathrm{~s}$, o tensoativo DMAB, menores volumes de T-80 enquando agitadas com uma maior barra de agitação. No caso dos imunolipossomos otimizados, empregou-se a DOPC, um regime de 3 pulsos de $30 \mathrm{~s}$ e uma centrifugação branda para remover partículas de dióxido de titânio.

Imunolipossomos não revelaram citotoxicidade e foram internalizados em menos de 30 minutos por neurônios, ao passo que as nanopartículas exibiram um perfil citotóxico e sua internalização é verificada em $12 \mathrm{~h}$.

A capacidade de tais sistemas otimizados em serem internalizados por neurônios consiste numa das etapas para a aplicação de tais carreadores para o tratamento e prevenção de doenças do SNC. Estudos futuros deverão comprovar a capacidade deles em transpor a BHE e coibir tais problemáticas. 


\section{REFERÊNCIAS}

ALLEN, T. M. Long-circulating (sterically stabilized) liposomes for targeted drug delivery. Trends in Pharmacological Sciences, v. 15, n. 7, p. 215-220, Julho 1994.

ALLEN, T. M.; CHONN, A. Large unilamellar liposomes with low uptake into the reticuloendothelial system. FEBS Letters, v. 223, n. 1, p. 42-46, Outubro 1987.

ALLEN, T. M.; CULLIS, P. R. Liposomal drug delivery systems: From concept to clinical applications. Advanced Drug Delivery Reviews, v. 65, p. 36-48, 2013.

ANDERSON, J. M.; SHIVE, M. S. Biodegradation and biocompatibility of PLA and PLGA microspheres. Advanced Drug Delivery Reviews, v. 28, p. 5-24, 1997.

AOKI, M. R., RA; HAGGERTY, JS;. Analysis and modeling of the ultrasonic dispersion technique. Adv Ceram Mater, v. 2, n. 3A, p. 209-212, 1987.

ARECHABALA, B. et al. Comparison of cytotoxicity of various surfactants tested on normal human fibroblast cultures using the neutral red test, MTT assay and LDH release. J Appl Toxicol, v. 19, n. 3, p. 163-165, May-Jun 1999.

ATTWOOD, S. J.; CHOI, Y.; LEONENKO, Z. Preparation of DOPC and DPPC Supported Planar Lipid Bilayers for Atomic Force Microscopy and Atomic Force Spectroscopy. Int J Mol Sci, v. 14, n. 2, p. 3514-3539, 2013.

BALLABH, P.; BRAUN, A.; NEDERGAARD, M. The blood-brain barrier: an overview: structure, regulation, and clinical implications. Neurobiol Dis, v. 16, n. 1, p. 1-13, Jun 2004.

BARENHOLZ, Y. Doxil(R)--the first FDA-approved nano-drug: lessons learned. J Control Release, v. 160, n. 2, p. 117-134, Jun 102012.

BARICHELLO, J. M. et al. Encapsulation of hydrophilic and lipophilic drugs in PLGA nanoparticles by the nanoprecipitation method. Drug Dev Ind Pharm, v. 25, n. 4, p. 471-476, Apr 1999.

BENNEWITZ, M. F.; SALTZMAN, W. M. Nanotechnology for delivery of drugs to the brain for epilepsy. Neurotherapeutics, v. 6, n. 2, p. 323-336, Apr 2009.

"De acordo com: ASSOCIAÇÃO BRASILEIRA DE NORMAS TÉCNICAS. NBR6023: Informação e documentação - Referências - Elaboração. Rio de Janeiro, 2002. 
BERRIDGE, M. V.; TAN, A. S. Characterization of the cellular reduction of 3-(4,5dimethylthiazol-2-yl)-2,5-diphenyltetrazolium bromide (MTT): subcellular localization, substrate dependence, and involvement of mitochondrial electron transport in MTT reduction. Arch Biochem Biophys, v. 303, n. 2, p. 474-482, Jun 1993.

BHARDWAJ, V. et al. PLGA nanoparticles stabilized with cationic surfactant: safety studies and application in oral delivery of paclitaxel to treat chemical-induced breast cancer in rat. Pharm Res, v. 26, n. 11, p. 2495-2503, Nov 2009.

BITOUNIS, D. et al. Optimizing Druggability through Liposomal Formulations: New Approaches to an Old Concept. ISRN Pharmaceutics, Fevereiro 2012.

BOX, G. E. P.; HUNTER, S. J.; HUNTER, W. G. Statistics for Experimenters. New Jersey: John Wiley \& Sons, Inc., 2005. 633 p.

BOZZUTO, G.; MOLINARI, A. Liposomes as nanomedical devices. Int $\mathbf{J}$ Nanomedicine, v. 10, p. 975-999, 2015.

BRUNSING, R.; OWENS, K. S.; PROSSNITZ, E. R. The G protein-coupled estrogen receptor (GPER) agonist G-1 expands the regulatory T-cell population under TH17polarizing conditions. Journal of Immunotherapy, v. 36, n. 3, p. 190-196, Abril 2013.

CAMPOS, P. R. F. Liposomes and nanotechnology in drug development: focus on neurological targets. Internaltional Journal of Nanomedicine, v. 8, p. 951-960, 2013.

CHANG, J. et al. Transferrin Adsorption onto PLGA Nanoparticles Governs Their Interaction with Biological Systems from Blood Circulation to Brain Cancer Cells. Pharmaceutical Research, v. 29, p. 1495-1505, 2012.

CHANG, W. K. et al. The comparison of protein-entrapped liposomes and lipoparticles: preparation, characterization, and efficacy of cellular uptake. Int J Nanomedicine, v. 6, p. 2403-2417, 2011.

CHIMENTO, A. et al. GPER agonist G-1 decreases adrenocortical carcinoma (ACC) cell growth in vitro and in vivo. Oncotarget, v. 6, n. 22, p. 19190-19203, Junho 2015.

$\mathrm{CHOU}, \mathrm{H}$. H. et al. Pegylated liposomal doxorubicin (Lipo-Dox) for platinum-resistant or refractory epithelial ovarian carcinoma: a Taiwanese gynecologic oncology group study with long-term follow-up. Gynecol Oncol, v. 101, n. 3, p. 423-428, Jun 2006.

CIANI, L. et al. DOTAP/DOPE and DC-Chol/DOPE lipoplexes for gene delivery studied by circular dichroism and other biophysical techniques. Biophys Chem, v. 127, n. 3, p. 213-220, May 2007. 
COBB, C. A.; COLE, M. P. Oxidative and nitrative stress in neurodegeneration. Neurobiol Dis, May 272015.

COOPER, D. L.; HARIRFOROOSH, S. Design and optimization of PLGA-based diclofenac loaded nanoparticles. PLoS One, v. 9, n. 1, p. e87326, 2014.

DANIEL, C. Use of Half-Normal Plots in Interpreting Factorial Two-Level Experiments. Technometrics, v. 1, n. 4, p. 311-341, 1959.

DOETSCH, F. et al. Subventricular zone astrocytes are neural stem cells in the adult mammalian brain. Cell, v. 97, n. 6, p. 703-716, Jun 111999.

DRAPPATZ, J. et al. Phase I study of GRN1005 in recurrent malignant glioma. Clin Cancer Res, v. 19, n. 6, p. 1567-1576, Mar 152013.

DU, R. et al. Antitumor effect of iRGD-modified liposomes containing conjugated linoleic acid-paclitaxel (CLA-PTX) on B16-F10 melanoma. Int J Nanomedicine, v. 9, p. 3091-3105, 2014.

DUMAN, O.; TUNÇ, S. Eletrokinetic and rheological properties of Na-bentonite in some electrolyte solutions. Microporous and Mesoporous Materials, v. 117, n. 1-2, p. 331338, 2009.

ERIKSSON, P. S. et al. Neurogenesis in the adult human hippocampus. Nat Med, v. 4, n. 11, p. 1313-1317, Nov 1998.

FAN, Y.; ZHANG, Q. Development of liposomal formulations: From concept to clinical investigations. Asian Journal of Phamaceutical Sciences, v. 8, n. 2, p. 81-87, 2013.

FANTINI, M. et al. Lipoplatin Treatment in Lung and Breast Cancer. Chemotherapy Research and Practice, v. 2011, n. 2011, p. 125192, 2010.

FASOL, U. et al. Vascular and pharmacokinetic effects of EndoTAG-1 in patients with advanced cancer and liver metastasis. Ann Oncol, v. 23, n. 4, p. 1030-1036, Apr 2012.

FDA. Guidance for Industry Considering Whether and FDA-Regulated Product Involves the Application of Nanotechnology. U.S. Departmanet of Health and Human Services - Food and Drug Administration Office of the Commissioner. 2014

FRADE, J. M.; OVEJERO-BENITO, M. C. Neuronal cell cycle: the neuron itself and its circumstances. Cell Cycle, v. 14, n. 5, p. 712-720, 2015. 
FRESTA, M. et al. Preparation and characterization of polyethyl-2-cyanoacrylate nanocapsules containing antiepileptic drugs. Biomaterials, v. 17, n. 8, p. 751-758, Apr 1996.

GABIZON, A.; SHMEEDA, H.; BARENHOLZ, Y. Pharmacokinetics of pegylated liposomal Doxorubicin: review of animal and human studies. Clinical Pharmacokinetics, v. 42, n. 5, p. 419-436, Abril 2003.

GEIGER, B.; AYALON, O. Cadherins. Annu Rev Cell Biol, v. 8, p. 307-332, 1992.

GIROTRA, P.; SINGH, S. K. A Comparative Study of Orally Delivered PBCA and ApoE Coupled BSA Nanoparticles for Brain Targeting of Sumatriptan Succinate in Therapeutic Management of Migraine. Pharm Res, v. 33, n. 7, p. 1682-1695, Jul 2016.

GOMAA, Y. A. et al. Flux of ionic dyes across microneedle-treated skin: effect of molecular characteristics. Int J Pharm, v. 438, n. 1-2, p. 140-149, Nov 152012.

GOMMANS, G. M. et al. 99mTc Nanocoll: a radiopharmaceutical for sentinel node localisation in breast cancer--in vitro and in vivo results. Appl Radiat Isot, v. 67, n. 9, p. 1550-1558, Sep 2009.

GOSSMANN, R.; LANGER, K.; MULAC, D. New Perspective in the Formulation and Characterization of Didodecyldimethylammonium Bromide (DMAB) Stabilized Poly(Lactic-co-Glycolic Acid) (PLGA) Nanoparticles. PLoS One, v. 10, n. 7, p. e0127532, 2015.

GRABRUCKER, A. M. et al. Nanoparticle transport across the blood brain barrier. Tissue Barriers, v. 4, n. 1, p. e1153568, Jan-Mar 2016.

GREENHALGH, A. D. et al. Translational pharmacokinetics: challenges of an emerging approach to drug development in stroke. Expert Opinion on Drug Metabolism \& Toxicology, v. 7, n. 6, p. 681-695, Junho 2011.

HACKE, W. et al. Association of outcome with early stroke treatment: pooled analysis of ATLANTIS, ECASS, and NINDS rt-PA stroke trials. Lancet, v. 363, n. 9411, p. 768774, Mar 62004.

HAU, P. et al. Pegylated liposomal doxorubicin-efficacy in patients with recurrent highgrade glioma. Cancer, v. 100, n. 6, p. 1199-1207, Mar 152004.

HEIDEL, J. D.; DAVIS, M. E. Clinical developments in nanotechnology for cancer therapy. Pharm Res, v. 28, n. 2, p. 187-199, Feb 2011. 
HOLMKVIST, A. D. et al. Hydrophobic ion pairing of a minocycline/Ca(2+)/AOT complex for preparation of drug-loaded PLGA nanoparticles with improved sustained release. Int J Pharm, v. 499, n. 1-2, p. 351-357, Feb 292016.

ISO. ISO-22412:2008, Particle size analysis - Dynamic light scattering (DLS). International Organization for Standarization, p. 17, $2008 \mathrm{a}$.

ISO/TS-27687:2008 - Nanotechnologies -- Terminology and definitions for nano-objects -- Nanoparticle, nanofibre and nanoplate. International Organization for Standarization, p. 16, $2008 \mathrm{~b}$.

ITOGA, M. et al. G-protein-coupled estrogen receptor agonist suppresses airway inflammation in a mouse model of asthma through IL-10. PLoS One, v. 10, n. 3, Março 2015.

JAIN, R. A. The manufacturing techniques of various drug loaded biodegradable poly(lactide-co-glycolide) (PLGA) devices. Biomaterials, v. 21, p. 2475-2490, 2000.

JELLINGER, K. A. Cell death mechanisms in neurodegeneration. J Cell Mol Med, v. 5, n. 1, p. 1-17, Jan-Mar 2001.

$\mathrm{KIM}, \mathrm{M}$. S. et al. Effect of solvent type on the nanoparticle formation of atorvastatin calcium by the supercritical antisolvent process. Chem Pharm Bull (Tokyo), v. 60, n. 4, p. 543-547, 2012.

KOLEY, D.; BARD, A. J. Triton X-100 concentration effects on membrane permeability of a single HeLa cell by scanning electrochemical microscopy (SECM). Proc Natl Acad Sci U S A, v. 107, n. 39, p. 16783-16787, Sep 282010.

KUO, Y. C.; YU, H. W. Surface coverage of didecyl dimethylammonium bromide on poly(lactide-co-glycolide) nanoparticles. Colloids Surf B Biointerfaces, v. 84, n. 1, p. 253-258, May 12011.

LAMPRECHT, A. et al. Biodegradable nanoparticles for targeted drug delivery in treatment of inflammatory bowel disease. The Journal of Pharmacology and Experimental Therapeutics, v. 299, n. 2, p. 775-781, Julho 2001.

LASORELLA, A.; IAVARONE, A.; ISRAEL, M. A. Differentiation of neuroblastoma enhances Bcl-2 expression and induces alterations of apoptosis and drug resistance. Cancer Res, v. 55, n. 20, p. 4711-4716, Oct 151995.

LEFFERTS, J. A.; JANNETTO, P.; TSONGALIS, G. J. Evaluation of the Nanosphere Verigene System and the Verigene F5/F2/MTHFR Nucleic Acid Tests. Exp Mol Pathol, v. 87, n. 2, p. 105-108, Oct 2009. 
LEONARD, R. C. et al. Improving the therapeutic index of anthracycline chemotherapy: focus on liposomal doxorubicin (Myocet). Breast, v. 18, n. 4, p. 218224, Aug 2009.

LI, Z. et al. Characterization of nebulized liposomal amikacin (Arikace) as a function of droplet size. J Aerosol Med Pulm Drug Deliv, v. 21, n. 3, p. 245-254, Sep 2008.

LIN, S. Y. et al. In vitro degradation and dissolution behaviours of microspheres prepared by three low molecular weight polyesters. Journal of Microencapsulation, v. 17, n. 5, p. 577-586, 2000.

LIU, X. et al. Protective effects of cationic bovine serum albumin-conjugated PEGylated tanshinone IIA nanoparticles on cerebral ischemia. Biomaterials, v. 34, p. 817-830, 2013.

LU, J. M. et al. Current advances in research and clinical applications of PLGA-based nanotechnology. Expert Rev Mol Diagn, v. 9, n. 4, p. 325-341, May 2009.

MANJAPPA, A. S. et al. Antibody derivatization and conjugation strategies: Application in preparation of stealth immunoliposome to target chemotherapeutics to tumor. Journal of Controlled Release, v. 150, p. 2-22, 2011.

MARTIN-BANDERAS, L. et al. Cannabinoid derivate-loaded PLGA nanocarriers for oral administration: formulation, characterization, and cytotoxicity studies. Int $\mathbf{J}$ Nanomedicine, v. 7, p. 5793-5806, 2012.

MARTIN, J. B. Molecular basis of the neurodegenerative disorders. N Engl J Med, v. 340, n. 25, p. 1970-1980, Jun 241999.

MATSUMURA, Y. et al. Phase I and pharmacokinetic study of MCC-465, a doxorubicin (DXR) encapsulated in PEG immunoliposome, in patients with metastatic stomach cancer. Annals of Oncology, v. 15, p. 517-525, 2004.

MDZINARISHVILI, A. et al. Engineering triiodothyronine (T3) nanoparticle for use in ischemic brain stroke. Drug Delivery and Translational Research, v. 3, p. 309-317, 2013.

MEHTA, S. L.; MANHAS, N.; RAGHUBIR, R. Molecular targets in cerebral ischemia for developing novel therapeutics. Brain Res Rev, v. 54, n. 1, p. 34-66, Apr 2007.

MEUNIER, F.; PRENTICE, H. G.; RINGDEN, O. Liposomal amphotericin B (AmBisome): safety data from a phase II/III clinical trial. J Antimicrob Chemother, v. 28 Suppl B, p. 83-91, Oct 1991. 
MEYERS, J. D. et al. Nanoparticles for imaging and treating brain cancer. Nanomedicine, v. 8, n. 1, p. 123-143, 2013.

MIYAZAWA, T. et al. Distribution of beta-carotene-encapsulated polysorbate 80coated poly(D, L-lactide-co-glycolide) nanoparticles in rodent tissues following intravenous administration. Int J Nanomedicine, v. 10, p. 7223-7230, 2015.

MONSKY, W. L. et al. Augmentation of transvascular transport of macromolecules and nanoparticles in tumors using vascular endothelial growth factor. Cancer Research, v. 59, p. 4129-4135, Agosto 1999.

MONTGOMERY, D. C. Design and Analysis of Experiments. New York: John Wiley \& Sons, Inc., 2001.

MONTGOMERY, D. C.; RUNGER, G. C. Applied Statistics and Probability for Engineers. New Jersey: John Wiley \& Sons, Inc., 2014.

MORROW, K. J., JR.; BAWA, R.; WEI, C. Recent advances in basic and clinical nanomedicine. Med Clin North Am, v. 91, n. 5, p. 805-843, Sep 2007.

MOSMANN, T. Rapid colorimetric assay for cellular growth and survival: application to proliferation and cytotoxicity assays. J Immunol Methods, v. 65, n. 1-2, p. 55-63, Dec 161983.

MUKHOPADHYAY, H. K. K., CHANDI CHARAN; DAS, SANJAY KUMAR; GHOSH, LAKSHMIKANTA; GUPTA, BIJAN KUMAR. Epilepsy and its Management: A Review. Journal of PharmaSciTech, v. 1, n. 2, p. 20-26, 2012.

ODA, T. et al. The nature of the globular- to fibrous-actin transition. Nature, v. 457, n. 7228, p. 441-445, Jan 222009.

PAHUJA, R. et al. Trans-blood brain barrier delivery of dopamine-loaded nanoparticles reverses functional deficits in parkinsonian rats. ACS Nano, v. 9, n. 5, p. 4850-4871, May 262015.

PANYAM, J.; LABHASETWAR, V. Biodegradable nanoparticles for drug and gene delivery to cells and tissues. Advanced Drug Delivery Reviews, v. 55, p. 329-347, 2003.

PAPAHADJOPOULOS, D. et al. Sterically stabilized liposomes: improvements in pharmacokinetics and antitumor therapeutic efficacy. Proceeding of the National Academy of Sciences of the United Stated of America, v. 88, p. 11460-11464, Dezembro 1991. 
PARDRIDGE, W. M. The Blood-Brain Barrier Bottleneck in Brain drug development. The Journal of the American Society for Experimental NeuroTherapeutics, v. 2, p. 3-14, Janeiro 2005.

PARDRIDGE, W. M. Drug transport across the blood-brain barrier. J Cereb Blood Flow Metab, v. 32, n. 11, p. 1959-1972, Nov 2012.

PARDRIDGE, W. M.; BOADO, R. J.; FARRELL, C. R. Brain-type glucose transporter (GLUT-1) is selectively localized to the blood-brain barrier. Studies with quantitative western blotting and in situ hybridization. J Biol Chem, v. 265, n. 29, p. 18035-18040, Oct 151990.

PARDRIDGE, W. M.; EISENBERG, J.; YANG, J. Human blood-brain barrier insulin receptor. J Neurochem, v. 44, n. 6, p. 1771-1778, Jun 1985.

Human blood-brain barrier transferrin receptor. Metabolism, v. 36, n. 9, p. 892-895, Sep 1987.

PARIA, S.; KHILAR, K. C. A review on experimental studies of surfactant adsorption at the hydrophilic solid-water interface. Adv Colloid Interface Sci, v. 110, n. 3, p. 7595, Aug 312004.

PARK, K. Nanotechnology: What it can do for drug delivery. J Control Release, v. 120, n. 1-2, p. 1-3, Jul 162007.

PERRIN, B. J.; ERVASTI, J. M. The actin gene family: function follows isoform. Cytoskeleton (Hoboken), v. 67, n. 10, p. 630-634, Oct 2010.

RAMGE, P. U., R. E.; OLTROGGE, J. B.; ZENKER, D.; BEGLEY, D.; KREUTER, J.; VON BRIESEN, $\mathrm{H}$. Polysorbate- 80 coating enhances uptake of polybutylcyanoacrylate (PBCA)-nanoparticles by human and bovine primary brain capillary endothelial cells. European Journal of Neuroscience, v. 12, p. 1931-1940, 2000.

RISS, T. L. et al. Cell Viability Assays. In: SITTAMPALAM, G. S.;COUSSENS, N. P., et al (Ed.). Assay Guidance Manual. Bethesda (MD): Eli Lilly \& Company and the National Center for Advancing Translational Sciences, 2004. Disponível em: < http://www.ncbi.nlm.nih.gov/pubmed/23805433 >. Acesso em: 3 jan 2017.

ROCA, M. et al. Linear assembly of gold nanoparticle clusters via centrifugation. Langmuir, v. 26, n. 3, p. 2035-2041, Feb 22010.

RODRIGUES, J. R. D. S., N. B.; MUNHOZ, C. D. Participação do GPER na modulação astrocitária na vigência de estímulos inflamatórios in vitro similares aos presentes na Esclerose Múltipla. 2015 IBRO 2015. 
ROTMAN, M. et al. Enhanced glutathione PEGylated liposomal brain delivery of an anti-amyloid single domain antibody fragment in a mouse model for Alzheimer's disease. Journal of Controlled Release, v. 203, p. 40-50, 2015.

SAHOO, S. K. et al. Residual polyvinyl alcohol associated with poly (D,L-lactide-coglycolide) nanoparticles affects their physical properties and cellular uptake. Journal of Controlled Release, v. 82, p. 105-114, 2002.

SALMASO, S.; CALICETI, P. Stealth properties to improve therapeutic efficacy of drug nanocarriers. J Drug Deliv, v. 2013, p. 374252, 2013.

SANDRA, A.; PAGANO, R. E. Liposome-cell interactions. Studies of lipid transfer using isotopically asymmetric vesicles. J Biol Chem, v. 254, n. 7, p. 2244-2249, Apr 101979.

SANNA, V.; SECHI, M. Nanoparticle therapeutics for prostate cancer treatment. Maturitas, v. 73, n. 1, p. 27-32, Sep 2012.

SANTHANALAKSHMI, J.; BALAJI, S. Adsorption Studies of Nonionic Surfactants on Charcoal and Alumina in Aromatic Solvents. Journal of Colloid and Interface Science, v. 179, p. 517-521, 1996.

SCHINKEL, A. H. P-Glycoprotein, a gatekeeper in the blood-brain barrier. Adv Drug Deliv Rev, v. 36, n. 2-3, p. 179-194, Apr 51999.

SCHNYDER, A.; HUWYLER, J. Drug Transport to Brain with Targeted Liposomes. The Journal of the American Society for Experimental NeuroTherapeutics, v. 2, p. 99107, Janeiro 2005.

SEMETE, B. et al. In vivo evaluation of the biodistribution and safety of PLGA nanoparticles as drug delivery systems. Nanomedicine, v. 6, n. 5, p. 662-671, Oct 2010.

SEVIGNY, J. et al. The antibody aducanumab reduces Abeta plaques in Alzheimer's disease. Nature, v. 537, n. 7618, p. 50-56, 2016.

SKOCAJ, M. et al. Titanium dioxide in our everyday life; is it safe? Radiol Oncol, v. 45, n. 4, p. 227-247, Dec 2011.

SMOLUCHOWSKI, M. Mathematical theory of the kinetics of the coagulation. Zeitschrift für physikalische Chemie, v. 92, p. 129, 1917. 
SONG, K. C. et al. The effect of type of organic phase solvents on the particle size of poly(D,L-lactide-co-glycolide) nanoparticles. Colloids and SUrface A:Physicochem, Eng. Aspects, v. 276, n. 2006, p. 162-167, 2006.

SUZUKI, R. et al. Effective anti-tumor activity of oxaliplatin encapsulated in transferrinPEG-liposome. International Journal of Pharmaceutics, v. 346, p. 143-150, 2008.

SZOKA, F., JR.; PAPAHADJOPOULOS, D. Comparative properties and methods of preparation of lipid vesicles (liposomes). Annu Rev Biophys Bioeng, v. 9, p. 467-508, 1980.

TAHARA, K.; YAMAMOTO, H.; KAWASHIMA, Y. Cellular uptake mechanisms and intracellular distributions of polysorbate 80-modified poly (D,L-lactide-co-glycolide) nanospheres for gene delivery. Eur J Pharm Biopharm, v. 75, n. 2, p. 218-224, Jun 2010.

TAUROZZI, J. S.; HACKLEY, V. A.; WIESNER, M. R. Ultrasonic dispersion of nanoparticles for environmental, health and safety assessment--issues and recommendations. Nanotoxicology, v. 5, n. 4, p. 711-729, Dec 2011.

THOMAS, B.; BEAL, M. F. Parkinson's disease. Hum Mol Genet, v. 16 Spec No. 2, p. R183-194, Oct 152007.

TROTTA, E. et al. 1H NMR study of [d(GCGATCGC)]2 and its interaction with minor groove binding 4',6-diamidino-2-phenylindole. J Biol Chem, v. 268, n. 6, p. 3944-3951, Feb 251993.

VILLEGAS, J. C.; BROADWELL, R. D. Transcytosis of protein through the mammalian cerebral epithelium and endothelium. II. Adsorptive transcytosis of WGA-HRP and the blood-brain and brain-blood barriers. J Neurocytol, v. 22, n. 2, p. 67-80, Feb 1993.

WAGNER, K., R. Cerebral Ischemia: Molecular Mechanisms and Protective Therapies. In: GILMAN, S. (Ed.). Neurobiology of Disease. USA: Elsevier, 2007. cap. 26, p.271279.

WALKEY, C. D. et al. Nanoparticle size and surface chemistry determine serum protein adsorption and macrophage uptake. J Am Chem Soc, v. 134, n. 4, p. 21392147, Feb 012012.

WANG, $\mathrm{H}$. et al. Tetracycline-grafted PLGA nanoparticles as bone-targeting drug delivery system. Int J Nanomedicine, v. 10, p. 5671-5685, 2015. 
WANG, P. Y.; WANG, H. P.; LI, G. W. [Protective effect of pueraria flavonoid on the cerebral ischemic reperfusion injury in rats]. Zhongguo Zhong Yao Za Zhi, v. 31, n. 7, p. 577-579, Apr 2006.

WEI, W. et al. The activation of G protein-coupled receptor 30 (GPR30) inhibits proliferation of estrogen receptor-negative breast cancer cells in vitro and in vivo. Cell death \& disease, v. 5, n. e1428, Outubro 2014.

WOHLFART, S. et al. Efficient Chemotherapy of Rat Glioblastoma Using DoxorubicinLoaded PLGA Nanoparticles with Different Stabilizers. European Journal of Pharmaceutics and Biopharmaceutics, v. 74, p. 157-163, 2010.

WU, D.; PARDRIDGE, W. M. Drug targeting of a peptide radiopharmaceutical through the primate blood-brain barrier in vivo with a monoclonal antibody to the human insulin receptor. The Journal of Clinical Investigation, v. 100, n. 7, p. 1804-1812, Outubro 1997.

YADAV, A. M., MS; SHETE, AS; SFURTI, S. Stability Aspects of Liposomes. Indian Journal of Pharmaceutical Education and Research, v. 45, n. 4, p. 402-413, 2011.

ZHANG, Q. et al. Activation of G-protein coupled estrogen receptor inhibits the proliferation of cervical cancer cells via sustained activation of ERK1/2. Cell Biochemistry and Function, v. 33, n. 3, p. 134-142, Abril 2015.

ZHANG, Z. et al. Polymeric nanoparticles-based topical delivery systems for the treatment of dermatological diseases. Wiley Interdiscip Rev Nanomed Nanobiotechnol, v. 5, n. 3, p. 205-218, May-Jun 2013.

ZHENG, X. et al. Intranasal H102 Peptide-Loaded Liposomes for Brain Delivery to Treat Alzheimer's Disease. Pharm Res, v. 32, n. 12, p. 3837-3849, Dec 2015. 